\title{
Designing Dual Inhibitors of Anaplastic Lymphoma Kinase (ALK) and Bromodomain-4 (BRD4) by Tuning Kinase Selectivity
}

\author{
Ellen Watts, ${ }^{\dagger}$ David Heidenreich, ${ }^{\ddagger}{ }^{\S}$ Elizabeth Tucker, ${ }^{\|}$Monika Raab, ${ }^{\perp}$ Klaus Strebhardt, ${ }^{\perp}$

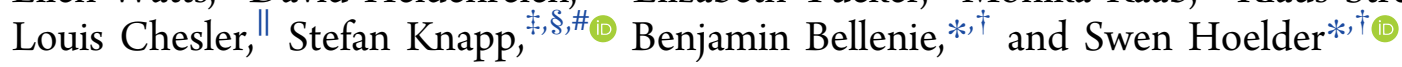 \\ ${ }^{\dagger}$ Cancer Research UK Cancer Therapeutics Unit at The Institute of Cancer Research, London SM2 5NG, U.K. \\ ${ }^{\ddagger}$ Institute for Pharmaceutical Chemistry, Johann Wolfgang Goethe-University, Max-von-Laue-Strasse 9, D-60438 Frankfurt am \\ Main, Germany \\ ${ }^{\S}$ Structural Genomics Consortium, BMLS, Goethe-University Frankfurt, 60438 Frankfurt, Germany \\ "Paediatric and Solid Tumour Biology and Therapeutics Group, The Institute of Cancer Research, 15 Cotswold Road, London SM2 \\ 5NG, U.K. \\ ${ }^{\perp}$ Department of Gynecology and Obstetrics, Johann Wolfgang Goethe-University, Theodor-Stern Kai 7, 60590 Frankfurt am Main, \\ Germany

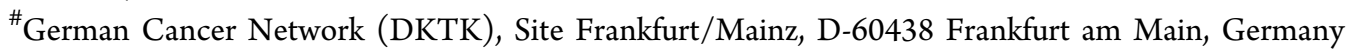

\section{Supporting Information}

ABSTRACT: Concomitant inhibition of anaplastic lymphoma kinase (ALK) and bromodomain-4 (BRD4) is a potential therapeutic strategy for targeting two key oncogenic drivers that co-segregate in a significant fraction of high-risk neuroblastoma patients, mutation of ALK and amplification of MYCN. Starting from known dual polo-like kinase (PLK)1-BRD4 inhibitor BI-2536, we employed structure-based design to redesign this series toward compounds with a dual ALK-BRD4 profile. These efforts led to compound (R)-2-
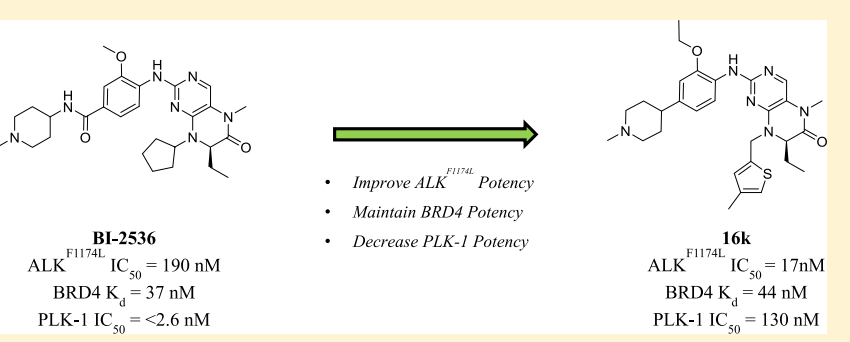
((2-ethoxy-4-(1-methylpiperidin-4-yl)phenyl)amino)-7-ethyl-5-methyl-8-((4-methylthiophen-2-yl)methyl)-7,8-dihydropteridin-6(5H)-one (16k) demonstrating improved ALK activity and significantly reduced PLK-1 activity, while maintaining BRD4 activity and overall kinome selectivity. We demonstrate the compounds' on-target engagement with ALK and BRD4 in cells as well as favorable broad kinase and bromodomain selectivity.

\section{INTRODUCTION}

Neuroblastoma is a pediatric cancer of neural crest origin and is the most common extracranial solid tumor in childhood. ${ }^{1}$ In high-risk patients, mutations within the kinase domain of the anaplastic lymphoma kinase (ALK), such as $\mathrm{ALK}^{\mathrm{F} 1174 \mathrm{~L}}$, cosegregate with amplification of the MYCN gene. Since the ALK mutation increases transcription and expression of $\mathrm{MYCN}$, both oncogenic gene changes cooperate to upregulate this well-established driver of neuroblastoma proliferation, resulting in poor prognosis and clinical outcome. ${ }^{2}$

Several selective inhibitors of the ALK kinase have been disclosed and entered clinical trials for different indications. However, crizotinib is clinically ineffective in neuroblastoma and many second-generation ALK inhibitors are predicted to be ineffective for neuroblastoma patients harboring the F1174L mutation due to insufficient inhibition of the mutant kinase. ${ }^{3}$ Recently, the third-generation ALK inhibitor lorlatinib was shown to potently inhibit $\mathrm{ALK}^{\mathrm{F} 1174 \mathrm{~L}}$ and has now entered phase I clinical trials in relapsed or refractory neuroblastoma patients. ${ }^{4}$

Inhibition of bromodomain-4 (BRD4) has recently emerged as an essential transcriptional co-regulator of $\mathrm{MYCN}$, and inhibition of the bromodomain has been shown to be an effective therapeutic approach to target dysregulated MYCN in neuroblastoma. ${ }^{5-7}$ Several compounds have progressed to clinical trials for adult malignancies but have yet to reach pediatric trials. ${ }^{8,9}$

It is increasingly recognized that targeting multiple pathways that support cancer growth and survival is necessary to treat aggressive cancers, provide a more durable response, and overcome resistance. $^{10}$ Given the clinical challenge that highrisk neuroblastoma cases pose, combining ALK and BRD4 inhibition may represent an effective therapeutic approach for this high medical need. Combining both ALK and BRD4 inhibition would serve two purposes. First, it would target the two most common and co-segregating events that drive highrisk neuroblastoma and curb MYCN expression, potentially resulting in strong antiproliferative or proapoptopic effects. Moreover, blocking two targets at once reduces the risk of resistance to the therapy since the probability of clonal

Received: December 13, 2018

Published: February 21, 2019 


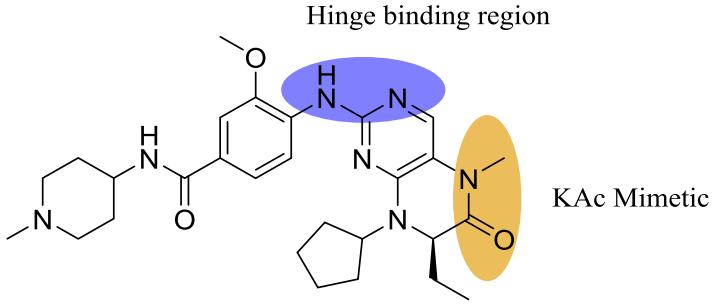

$$
\begin{gathered}
\text { ALK }^{\text {F1174L }_{\text {IC }}} \text { : }: 190 \mathrm{nM} \\
\text { ALKWT IC } \\
\mathbf{5 0}: 390 \mathrm{nM} \\
\text { BRD4(1) K } \mathbf{K}_{\mathbf{d}}: 37 \mathrm{nM} \\
\text { PLK-1 IC } \text { I }_{\mathbf{5 0}}:<2.6 \mathrm{nM}
\end{gathered}
$$

BI-2536

Figure 1. Biochemical potencies of the dual PLK-1-BRD4 inhibitor BI-2536 and moieties of the molecule that form key interactions with BRD4 (orange) and the PLK-1 hinge region (violet).

(a)

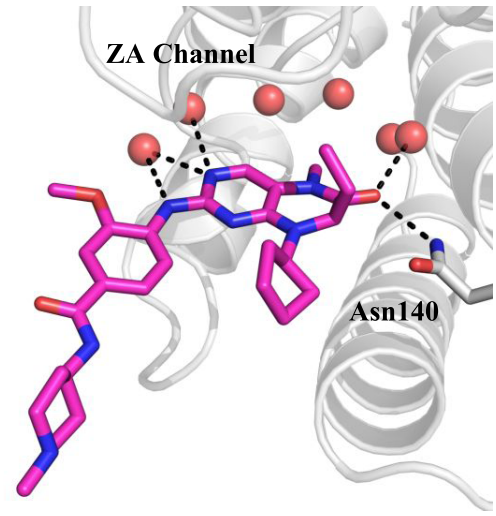

(c)

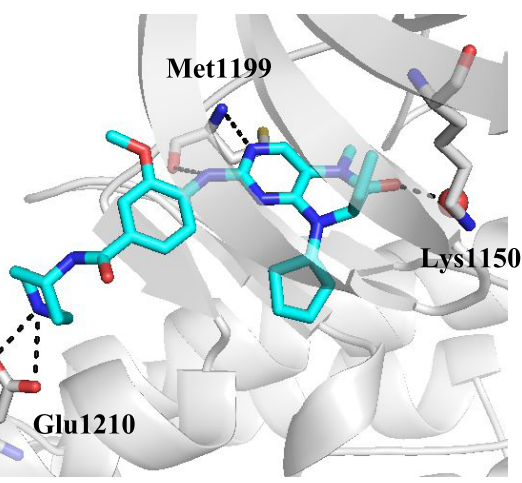

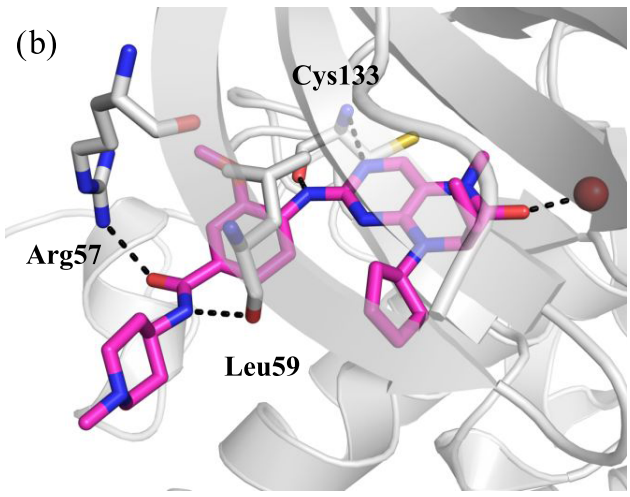

(d)

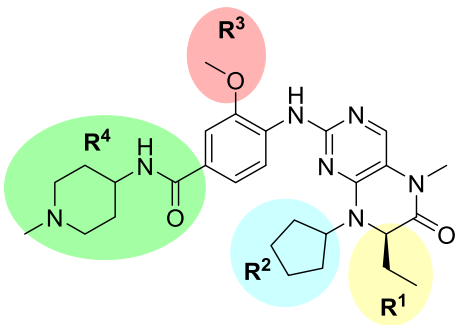

Figure 2. X-ray structures of BI-2536 in complex with (a) BRD4 (4OGI) and (b) PLK-1 (2RKU) highlighting key interactions. (c) Docking pose generated using Glide showing BI-2536 in complex with ALK (2XB7), highlighting key interactions. (d) Four chosen areas for modification on BI2536.

adaptation to targeted therapy is lower for combination therapies. ${ }^{11}$

A key barrier in clinical implementation of new agents or treatment strategies in children is that combination trials of multiple drugs are challenging in pediatric patients. This is in part due to the increased chance of off-target toxicity when two agents are tested and length of trials because tolerable dose must be established for each new agent separately in very small patient populations.

An alternative approach to using two drugs in combination is to explore dual inhibitors that block both targets of a therapeutic combination, in the case of high-risk neuroblastoma, BRD4 and $\mathrm{ALK}^{\mathrm{F} 1174 \mathrm{~L}}$. A dual inhibitor is likely to reduce the liabilities associated with combination treatments, particularly, off-target toxicities, drug-drug interactions, and additive effects. Furthermore, combinatorial treatment in the form of a dual inhibitor reduces the length and complexity of trials as well as costs. ${ }^{10,12,13}$
Dual inhibitors are thus an attractive therapeutic approach, but the design and development of drugs that specifically inhibit two targets, particularly, where these are structurally distinct and not members of the same protein family, are challenging. In particular, combining two pharmacophores into a single druglike compound while also achieving selectivity and physicochemical and pharmacokinetics properties consistent with clinical development is regarded as very difficult. ${ }^{10}$

However, precedent for dual kinase-bromodomain inhibitors has recently emerged. Through systematic screening efforts, Ember et al. and Ciceri et al. identified a total of 24 kinase inhibitors that interact with BRD4. ${ }^{14,15}$ Cocrystal structures of these dual inhibitors revealed insights into how the BRD4 and kinase pharmacophores can be combined into a single druglike molecule. Although these reports provide important precedence for dual kinase-bromodomain inhibition and structural insights, the combination of bromodomain and kinase inhibited by these dual inhibitors was discovered 


\section{Scheme 1}

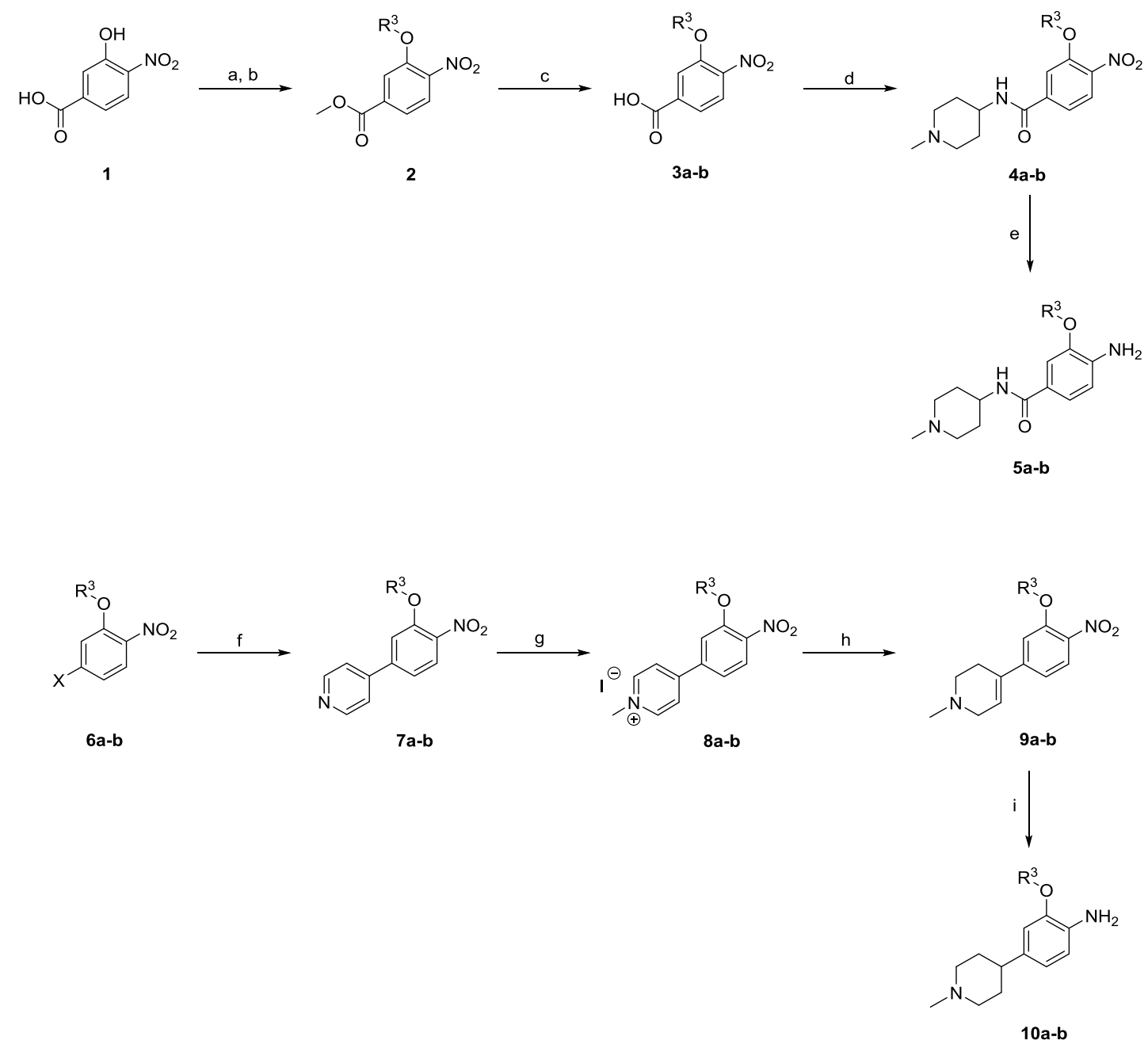

${ }^{a}$ Reagents and conditions: (a) $\mathrm{SOCl}_{2}, \mathrm{MeOH}, 70{ }^{\circ} \mathrm{C}, 90 \%$; (b) 1-iodo-2-methylpropane, $\mathrm{K}_{2} \mathrm{CO}_{3}$, dimethylformamide (DMF), $50{ }^{\circ} \mathrm{C}$, $88 \%$; (c) $\mathrm{LiOH}, \mathrm{H}_{2} \mathrm{O}$, room temperature (rt), 71\%; (d) 4-amino-1-methylpiperidine, HBTU, Et ${ }_{3} \mathrm{~N}, \mathrm{DMF}, \mathrm{rt}, 77-86 \% ;(\mathrm{e}) \mathrm{SnCl}_{2} \cdot 2 \mathrm{H}_{2} \mathrm{O}, \mathrm{EtOAc} / \mathrm{EtOH}^{\circ}$, 10:3, $50{ }^{\circ} \mathrm{C}, 53-55 \%$; (f) 4-pyridylboronic acid, $\mathrm{PdCl}_{2}\left(\mathrm{PPh}_{3}\right)_{2}, \mathrm{Na}_{2} \mathrm{CO}_{3}$, dioxane/water 6:1, $110{ }^{\circ} \mathrm{C}$, 54-65\%; (g) $\mathrm{MeI}, \mathrm{MeCN}, 50{ }^{\circ} \mathrm{C}, 91-99 \%$; (h) $\mathrm{NaBH}_{4}, \mathrm{MeOH}, \mathrm{rt}, 56-95 \%$; (i) $\mathrm{H}_{2}, \mathrm{PtO}_{2}, \mathrm{AcOH}, 50$ psi, $75-85 \%$.

serendipitously by screening selective kinase inhibitors against the bromo- and extra-terminal domain (BET) bromodomains. To date, there are a few published reports of discovery efforts that aim to combine inhibition of a particular kinase with bromodomain inhibition into a single dual inhibitor to explore a specific disease hypothesis. ${ }^{16-18}$

Herein, we describe our efforts to discover dual ALK-BRD4 inhibitors to target both oncogenic drivers of high-risk neuroblastoma. We chose the dual polo-like kinase (PLK)$1-B R D 4$ inhibitor BI-2536 as our starting point and investigated if this inhibitor series can be reoptimized to show potent inhibition of mutant (F1174L) ALK kinase, reduced PLK-1 activity while maintaining BRD4 activity, and acceptable kinome selectivity.

\section{RESULTS AND DISCUSSION}

Our goal at the start of the project was to discover starting points that showed significant activity against BRD4 and the ALK kinase. We were particularly intrigued by the dual kinase-bromodomain inhibitor BI-2536 (Figure 1). The compound was discovered and developed as a PLK-1 kinase inhibitor but was found to potently inhibit BRD4 by Knapp and Schönbrunn's labs. ${ }^{14,19,20}$ BI-2536 has been reported to show high specificity within the kinase family, partially due to the methoxy substituent. Some kinases are not able to accommodate this substituent due to a steric clash with a larger tyrosine or tryptophan residue in the hinge region. Among the exceptions are PLK-1 and importantly ALK due to the presence of a smaller leucine at this position. ${ }^{21,22} \mathrm{We}$ thus hypothesized that although BI-2536 showed excellent overall kinase selectivity it may show sufficient activity against ALK and $\mathrm{ALK}^{\mathrm{F} 1174 \mathrm{~L}}$ to serve as a starting point. We analyzed the publicly available data, and indeed a $K_{d}$ of $160 \mathrm{nM}$ had been disclosed for $\mathrm{ALK}^{23}$ In our assays, BI-2536 showed comparable, albeit modest, activity $\left(\mathrm{IC}_{50} \mathrm{~s}\right.$ of 390 and 190 $\mathrm{nM}$ against $\mathrm{ALK}$ and $\mathrm{ALK}^{\mathrm{F} 1174 \mathrm{~L}}$, respectively).

In addition, we confirmed inhibition of BRD4 and PLK-1. In fact, the potency of BI-2536 against PLK-1 was beyond the dynamic range of the assay $\left(\mathrm{IC}_{50}<2.6 \mathrm{nM}\right)$ consistent with a published $K_{\mathrm{d}}$ of $0.19 \mathrm{nM}^{23}$

BI-2536 thus was a suitable starting point for the discovery of a dual ALK-BRD4 inhibitor, not least because it inhibited a few other kinases apart from PLK-1 and ALK. ${ }^{23}$ We thus decided to investigate if $\mathrm{BI}-2536$ can be optimized toward a 
Scheme 2<smiles>[R]C(N)C(=O)OC</smiles>

11a-c<smiles>[R]c1ccc(Nc2ncc3c(n2)N([R])C([R])C(=O)N3C)c([R])c1</smiles>

16a-I

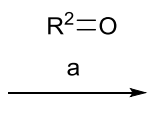<smiles>[R]c1ccc(N)c([R])c1</smiles>

Xa-b, Xa-b

$\longleftarrow$ e<smiles>[R]C1C(=O)N(C)c2cnc(Cl)nc2N1[R]</smiles><smiles>[10BH2]C</smiles>

12a-g<smiles>[R]NC([R])C(=O)OC</smiles><smiles>[3H]C</smiles><smiles>C1CCCC1</smiles><smiles>[R]C(C(=O)OC)N([R])c1nc(Cl)ncc1[N+](=O)[O-]</smiles><smiles>[R]C1C(=O)Nc2cnc(Cl)nc2N1[R]</smiles>

$\begin{aligned} \mathrm{f} \square & 16 \mathrm{f}, 16 \mathrm{~h} R^{2}=3-\mathrm{BrBn} \\ & 16 \mathrm{~g}, 16 \mathrm{i} R^{2}=\mathrm{Bn}\end{aligned}$

${ }^{a}$ Reagents and conditions: (a) $\mathrm{NaBH}(\mathrm{OAc})_{3}, \mathrm{NaOAc}$ 1,2-dichloroethane (DCE), rt, 16 h, 39-94\%; (b) 2,4-dichloronitropyrimidine, $\mathrm{NaHCO}_{3}$, cHex, 16 h, $50{ }^{\circ} \mathrm{C}, 34-90 \%$; (c) Fe, AcOH, 3-4 h, $70{ }^{\circ} \mathrm{C}, 25-42 \%$; (d) MeI, NaH, DMF, $0{ }^{\circ} \mathrm{C}$ to rt, 16 h, 59-75\%; (e) conc. HCl, EtOH/ dioxane $/ \mathrm{H}_{2} \mathrm{O}, 1: 1: 1,120{ }^{\circ} \mathrm{C}, 24-48 \mathrm{~h}, 7-53 \%$; (f) $\mathrm{H}_{2}, 10 \% \mathrm{Pd} \cdot \mathrm{C}, \mathrm{MeOH}, \mathrm{rt}, 1 \mathrm{~h}, 41-46 \%$.

dual ALK-BRD inhibitor. In particular, we sought to reduce activity against PLK-1, improve ALK activity, and maintain BRD4 activity. To analyze the scope for modifications as well as derive design hypotheses, we first analyzed the published structures of BI-2536 bound to BRD4 and PLK-1. ${ }^{14,21}$ In addition, we docked BI-2536 into ALK (2XB7) using Glide. We chose this structure for our docking experiment due to structural similarity between the ALK inhibitor NVPTAE $684^{22}$ and BI-2536, in particular, the aminopyrimidine hinge binding motif and the ortho-methoxy phenyl group.

In BRD4, the methyl amide moiety acts as the acetylated lysine (KAc) mimetic, interacting with Asn140 (Figure 2a). As described in more detail previously, ${ }^{14}$ additional interactions arise between the aminopyrimidine group and conserved waters in the ZA channel. The PLK-1-bound structure showed that the aminopyrimidine forms the key interactions with the hinge region of the kinase including Cys133 (Figure 2b). Docking into ALK not surprisingly predicted that aminopyrimidine of BI-2536 interacted with the ALK hinge region including residue Met1199 in a manner similar to that for PLK-1 (Figure 2c). The amide carbonyl was also predicted to interact with conserved water in the back of the ALK pocket.

Based on the ALK docking and BRD4 X-ray structure, we wanted to maintain the key kinase and bromodomain binding motifs on the dihydropteridinone core and thus decided to leave these regions of the compound untouched.

Our analysis also suggested that several positions around the core structure offered significant scope for modification (Figure $2 \mathrm{~d}$ ). The first area chosen for modification was the (R)-ethyl group $\left(\mathrm{R}^{1}\right)$, which fits into a hydrophobic pocket in both PLK-1 and BRD4. The docking of BI-2536 in ALK also suggests that the $(R)$-ethyl is pointing toward a pocket formed by residues Val1130, Ala1148, Lys1150, and Leu1196. It has been reported that changing the chirality of the ethyl group has little effect on the potency at PLK-1 and BRD4, whereas removing the group afforded a 26 -fold reduction in potency at BRD4. ${ }^{24,25}$
We were also interested in the cyclopentyl substitution off the dihydropteridinone core $\left(\mathrm{R}^{2}\right)$, which has been shown to be a region where BRD4 and PLK-1 selectivity can be tuned. ${ }^{24}$ For example, changing the cyclopentyl to a 3-bromobenzyl group increases BRD4 affinity due to improved hydrophobic interactions with the WPF shelf but decreases PLK-1 activity, suggesting that modifications in this region could be used to improve selectivity against PLK-1.

Next, we considered the methoxy group at the $\mathrm{R}^{3}$ position. Docking of BI-2536 suggests that the alkoxy group is pointing toward a known region for achieving ALK selectivity (Figure 2c). ${ }^{21}$ The majority of kinases have a bulkier residue at this region, allowing ALK selectivity to be achieved as seen with ceritinib and alectinib. ${ }^{26,27}$ In addition, larger alkoxy groups were known to improve interactions at BRD4. ${ }^{24}$ We thus hypothesized that larger alkoxy groups will lead to increased selectivity against PLK-1 while maintaining BRD4 activity.

The final area chosen for modification is the solvent channel methylpiperidine group $\left(\mathrm{R}^{4}\right)$. Published structure-activity relationship (SAR) data for ALK inhibitors suggested that a wide variety of groups are tolerated in this region. ${ }^{28-30} \mathrm{We}$ particularly decided to prepare analogues without the amide group to reduce PLK-1 activity by removing a hydrogenbonding interaction with Leu59 and a water molecule in the PLK-1 pocket.

Following this structure-based analysis and docking, we decided to focus modifications on four areas $\left(R^{1}, R^{2}, R^{3}\right.$, and $\mathrm{R}^{4}$ ) and to keep the dihydropteridinone core unchanged to maintain the key kinase and bromodomain binding interactions (Figure 2d).

Chemistry. We prepared a series of analogues of BI-2536 by adapting and optimizing previously described syntheses. ${ }^{31}$ For aniline intermediates containing the $\mathrm{R}^{3}$ and $\mathrm{R}^{4}$ modifications, two routes were used as shown in Scheme 1. For the amide-containing intermediates, the isobutyl group was first introduced by alkylation to 3-hydroxy-4-nitrobenzoic acid 1 via protection and subsequent deprotection of the benzoic 


\section{Scheme 3}

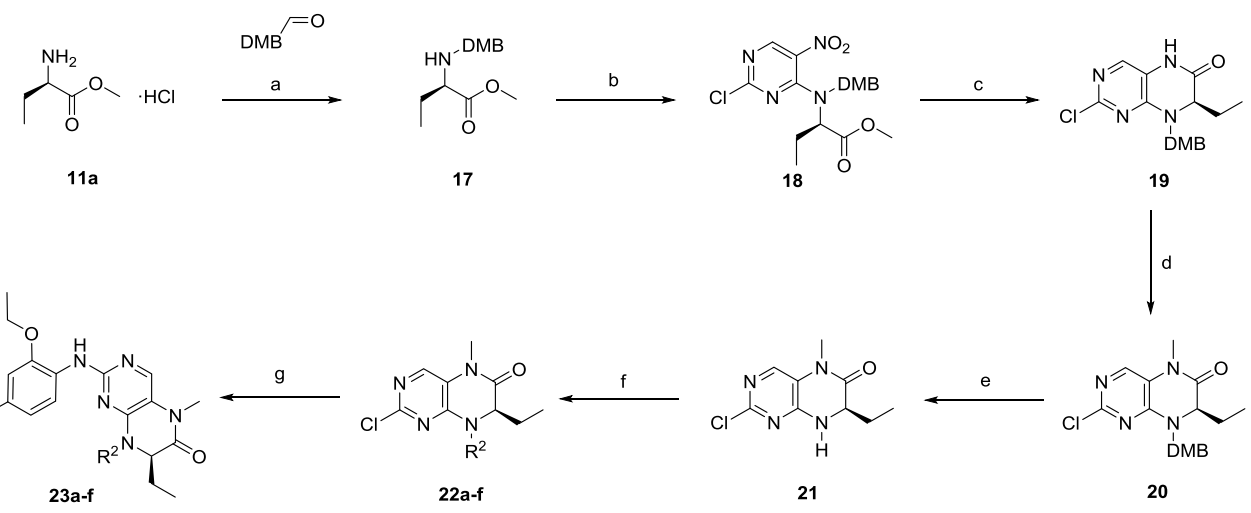

${ }^{a}$ Reagents and conditions: (a) $\mathrm{NaBH}(\mathrm{OAc})_{3}, \mathrm{NaOAc}, \mathrm{DCE}, \mathrm{rt}, 16 \mathrm{~h}, 97 \%$; (b) 2,4-dichloronitropyrimidine, $\mathrm{NaHCO}_{3}, \mathrm{cHex}, 16 \mathrm{~h}, 50{ }^{\circ} \mathrm{C}, 78 \%$; (c) $\mathrm{H}_{2}, \mathrm{PtO}_{2}, \mathrm{VO}(\mathrm{acac})_{2}$, tetrahydrofuran (THF), $98 \%$; (d) MeI, NaH, DMF, $0{ }^{\circ} \mathrm{C}$ to rt, $16 \mathrm{~h}, 86 \%$; (e) TFA, $80{ }^{\circ} \mathrm{C}, 4 \mathrm{~h}, 66 \%$; (f) $\mathrm{R}^{2}-\mathrm{X}, \mathrm{NaH}, \mathrm{DMF}$, rt, 16 h, 37-68\%; (g) conc. $\mathrm{HCl}, \mathrm{EtOH} /$ dioxane $/ \mathrm{H}_{2} \mathrm{O}, 1: 1: 1,120{ }^{\circ} \mathrm{C}, 24-48 \mathrm{~h}, 9-32 \%$.

acid. The 4-nitrobenzoic acid 3 a was coupled to 4-amino-1methylpiperidine using $O$-(benzotriazol-1-yl)- $N, N, N^{\prime}, N^{\prime}$-tetramethyluronium hexafluorophosphate (HBTU) to give amide $4 a$, followed by reduction using $\mathrm{SnCl}_{2}$ to give aniline 5a. The ethoxy analogue $\mathbf{5 b}$ was made via the same route from commercial compound $\mathbf{3 b}$. The synthesis of anilines 10a and 10b began with a Suzuki coupling between an alkoxynitrobenzene (6a and $\mathbf{6 b})$ and 4-pyridineboronic acid. Pyridines $7 \mathbf{a}$ and $7 \mathbf{b}$ were methylated to give $\mathbf{8 a}$ and $\mathbf{8 b}$ as the iodonium salts and then partially reduced using sodium borohydride (9a and $\mathbf{9 b}$ ). Hydrogenation of the dihydropyridine and nitro group gave aniline intermediates $10 \mathrm{a}$ and $\mathbf{1 0 b}$.

Meanwhile, intermediates $15 \mathbf{a}-\mathbf{g}$ were prepared according to Scheme 2. The appropriate amino acids $11 \mathrm{a}-\mathrm{c}$ underwent reductive amination with various aldehydes to give intermediates $12 \mathrm{a}-\mathrm{g}$ followed by regioselective $S_{N} A r$ with 2,5dichloro-4-nitropyrimidine to give $13 \mathbf{a}-\mathrm{g}$. Reductive heterocyclization using iron and acetic acid formed the dihydropteridinone scaffold $(\mathbf{1 4 a}-\mathbf{g})$, which was methylated to give intermediates $15 \mathbf{a}-\mathbf{g}$. The final step was acid-promoted $S_{N} A r$ between intermediates $\mathbf{1 5 a}-\mathbf{g}$ and anilines $\mathbf{5 a}, \mathbf{5 b}, \mathbf{1 0 a}$, and $10 \mathrm{~b}$ to yield final compounds 16a-l. Hydrogenation of compounds $16 \mathrm{f}$ and $16 \mathrm{~h}$ to remove the bromine yielded compounds $16 \mathrm{~g}$ and $\mathbf{1 6 i}$.

A key obstacle to preparing a significant number of analogues at the $\mathrm{R}^{2}$ position was that this substituent was introduced early and preparation of each example required five steps (Scheme 2). To our surprise, there was no precedent for synthetic routes for late stage variation at this position. To facilitate preparation of these derivatives, we developed an alternative approach. This approach maintained many elements of the initial route (Scheme 3 ) but started with a dimethoxybenzyl (DMB) protecting group at the $\mathrm{R}^{2}$ position. This strategy allowed us to remove the $\mathrm{DMB}$ group by refluxing the advanced intermediate (20) in trifluoroacetyl (TFA) and to subsequently introduce a wide range of $\mathrm{R}^{2}$ groups. A key challenge was that the reductive cyclization step on intermediate 18 employing iron and acetic acid partially removed the $\mathrm{DMB}$ group. We tested a range of hydrogenation conditions and, gratifyingly, $\mathrm{PtO}_{2}$ and $\mathrm{VO}(\mathrm{acac})_{2}$ gave an excellent yield of $98 \%{ }^{32}$ This route enabled us to prepare the key intermediate $\mathbf{2 1}$ on a multigram scale and convert it into a range of final products $(\mathbf{2 3 a}-\mathbf{f})$ in only two steps. Chiral shift NMR and chiral high-performance liquid chromatography
(HPLC) confirmed that no racemization took place under either the strongly basic or strongly acidic conditions. However, on a later repeat of this synthesis, we observed that epimerization could occur during the alkylation of 19 to yield 20. Reanalysis of previous batches confirmed that no epimerization was observed in the synthesis of the batch used to prepare the compounds described in this article (Supp. Figure 1). Furthermore, we reanalyzed products of reactions obtained under similar alkylating conditions (Scheme 2), confirming that racemization had not occurred here either. All final products described here were thus unaffected by the epimerization. However, due to the potential for racemization, we sought to reoptimize this step. By reducing the number of equivalents of sodium hydride or replacing this with a weaker base such as sodium hydroxide, enantiomeric ratios of 9:1 or greater could be obtained.

Biological Testing. Table 1 shows the derivatives of BI2536, modifying the $\mathrm{R}^{1}, \mathrm{R}^{2}, \mathrm{R}^{3}$, and $\mathrm{R}^{4}$ positions, and their activities at $\mathrm{ALK}^{\mathrm{F} 1174 \mathrm{~L}}, \mathrm{BRD} 4$, and PLK-1. The primary assays for biochemical testing were LanthaScreen for ALK ${ }^{\mathrm{F} 1174 \mathrm{~L}}$ and thermal shift against BRD4 (10 $\mu \mathrm{M}$ compound concentration). For selected compounds, this was followed by isothermal calorimetry against BRD4 and/or a PLK-1 Z-Lyte assay.

We started by analyzing the effect of the amide functionality in the solvent channel group $\left(R^{4}\right.$, Figure $\left.2 d\right)$. Removal of the amide group (compound 16a) had little effect against $\mathrm{ALK}^{\mathrm{F} 1174 \mathrm{~L}}$ and $\mathrm{BRD} 4$ potency. However, consistent with our hypothesis, it significantly decreased PLK-1-1 activity. Based on the measured $\mathrm{IC}_{50}$ value of $2.6 \mathrm{nM}, 16 \mathrm{a}$ showed a four-fold reduction in potency against PLK-1. The real effect on PLK-1 potency of this structural change may be significantly greater, however, as the potency of BI-2536 is below the dynamic range of our assay. Next, we analyzed the effect of the $\mathrm{R}^{3}$ substituent (Figure 2d) and prepared analogues with an ethoxy and an isobutoxy group at this position. The ethoxy group on compound 16c gave a small reduction in potency against $\mathrm{ALK}^{\mathrm{F} 1174 \mathrm{~L}}$ but a greater decrease in PLK-1 potency. An increase in the size of the group further to a butoxy group (compound 16b) resulted in a much larger drop in potency against $\mathrm{ALK}^{\mathrm{F} 1174 \mathrm{~L}}$. For BRD4, increasing the group to ethoxy and isobutoxy gave only a small decrease in activity, confirming the tolerance of larger groups at this position. Compound 16c provided the best balance of potency and selectivity thus far, so the ethoxy group was maintained. 
Table 1. Structure-Activity Relationships of the $R^{1}, R^{2}, R^{3}$, and $R^{4}$ Groups<smiles></smiles>

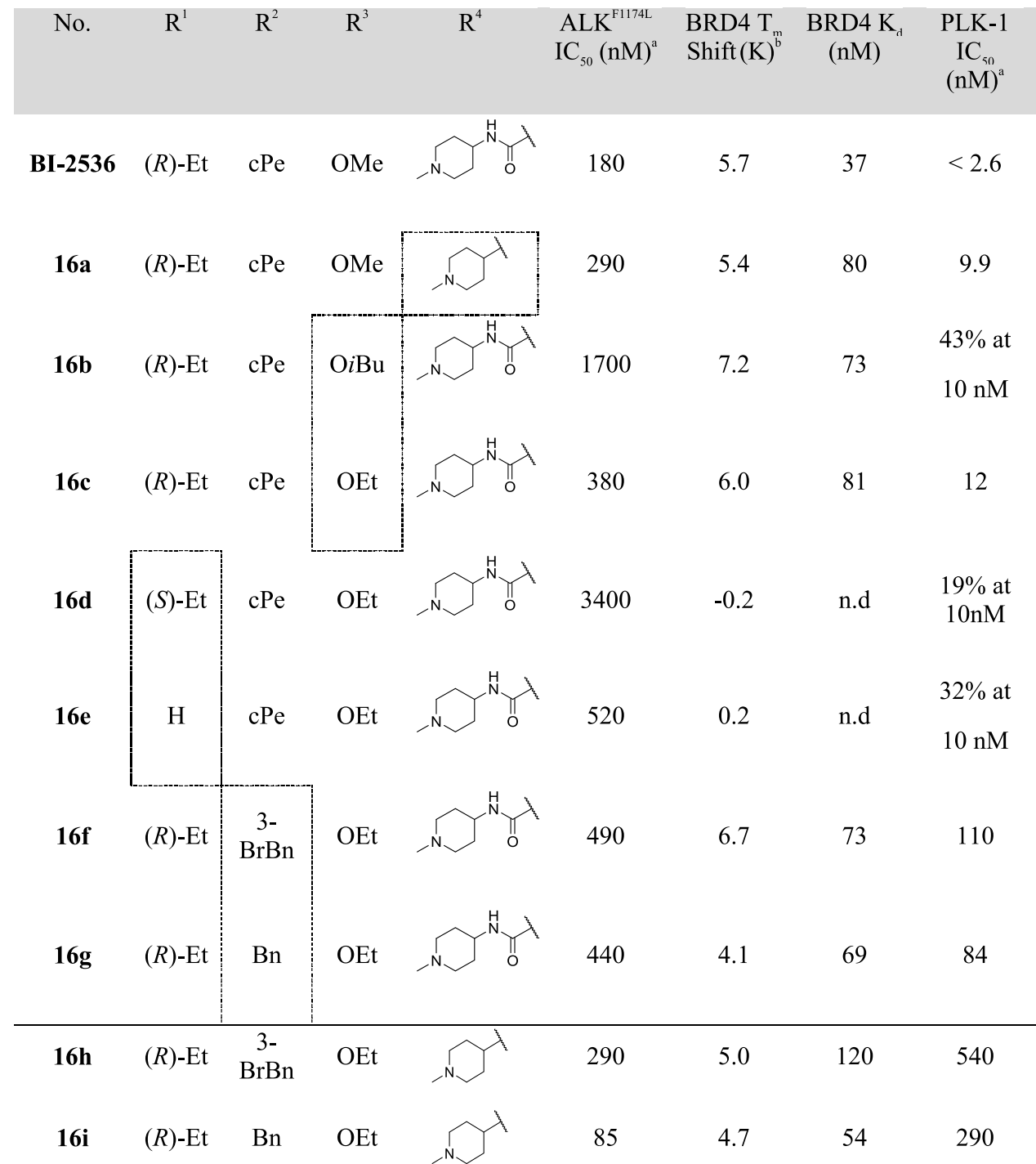

${ }^{a}$ Data represents the geometric mean; see Supp. Table 1 for full statistics. n.d. $=$ not determined. ${ }^{b} T_{\mathrm{m}}$ shift determined at compound concentration of $10 \mu \mathrm{M}, n=2$.

We started testing the effect of the $\mathrm{R}^{1}$ group by removing the $(R)$-ethyl group (16e). This removal reduced potency at BRD4 and PLK-1 very likely due to the loss of favorable interactions with the aforementioned pockets in BRD4 and PLK-1. Similarly, removal of the $(R)$-Et group also reduced $\mathrm{ALK}^{\mathrm{F} 1174 \mathrm{~L}}$ potency 3 -fold. We also synthesized the opposite enantiomer 16d, which also significantly reduced potency at all three targets. The reduction in PLK-1 and BRD4 activity was not in agreement with a published study but consistent with loss of productive interactions of the $(R)$-Et group with both PLK-1 and BRD4 and supported by modeling, which suggests that the ethyl group is too big to be accommodated on the lower face of the PLK-1 pocket. Finally, we analyzed substitution at the $\mathrm{R}^{2}$ position. Compounds $16 \mathrm{f}$ and $16 \mathrm{~g}$ with a 3-bromobenzyl and benzyl group, respectively, maintained BRD4 activity and led to a 30-40-fold decrease of the PLK-1 activity, as expected from previous reports. ${ }^{24}$ Compounds $16 \mathrm{f}$ and $\mathbf{1 6 g}$ were equipotent in $\mathrm{ALK}^{\mathrm{F} 1174 \mathrm{~L}}$ activity, compared with 16c. Importantly, the divergent SAR between ALK and PLK-1 with $\mathbf{1 6 f}$ and $\mathbf{1 6 g}$ supported our hypothesis that it is possible to optimize the ALK/PLK-1 selectivity window at the $\mathrm{R}^{2}$ position.

To conclude this initial SAR investigation, we combined modifications that showed a decrease in PLK-1 potency. Compounds $16 \mathrm{~h}$ and $16 \mathrm{i}$ with the combined modifications of the benzyl or 3-bromobenzyl group at $\mathrm{R}^{2}$, ethoxy group at $\mathrm{R}^{3}$, and removal of the amide at $\mathrm{R}^{4}$ gave a greater decrease in PLK1 activity (>100-200-fold). With benzyl compound 16i, we 
(a)

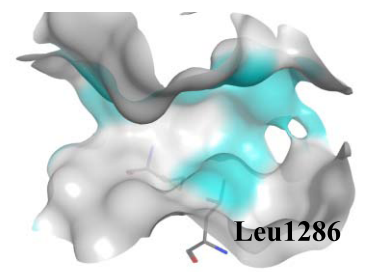

(b)

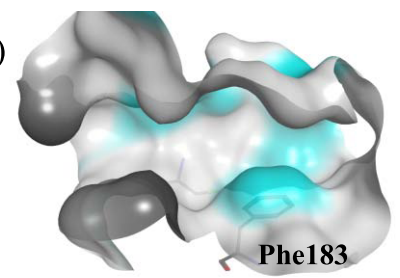

(c)

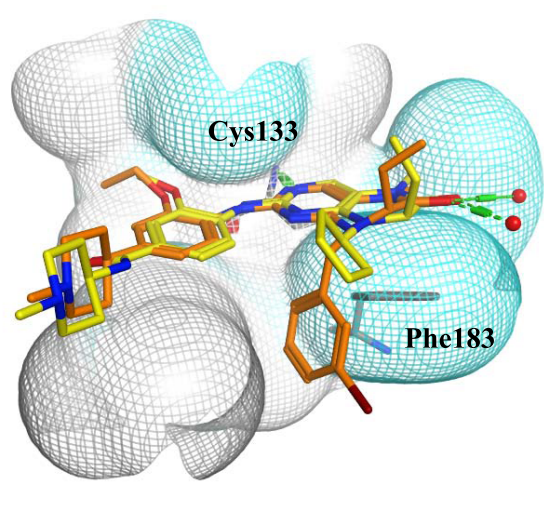

Figure 3. Surfaces of (a) ALK (2XB7) and (b) PLK-1 (2RKU) highlighting residues Leu1256 and Phe183. (c) Docking pose generated using Glide showing 16h (orange) in complex with PLK-1 (2RKU), overlaid with X-ray structure of BI-2536 (yellow) in PLK-1 (2RKU).

also saw a 2-fold increase in $\mathrm{ALK}^{\mathrm{F} 1174 \mathrm{~L}}$ potency and maintained potent BRD4 activity. This was the first analogue demonstrating greater potency at $\mathrm{ALK}^{\mathrm{F} 1174 \mathrm{~L}}$ than at PLK-1.

$\mathbf{R}^{2}$ SAR. So far, the greatest change in PLK-1 activity resulted from modifying the cyclopentyl to a benzyl or 3bromobenzyl group (Table 1). Further inspection of this region in ALK and PLK-1 structures shows that PLK-1 has a larger phenylalanine residue (Phe183) at the bottom of this pocket compared with a smaller leucine residue (Leu1286) in ALK (Figure 3a,b). We hypothesized that PLK-1 inhibition would be less tolerant to substitution at the $\mathrm{R}^{2}$ position due to this geometric constraint compared to that in the more open ALK structure. To investigate this hypothesis further, we performed docking studies of 3-bromobenzyl analogue $16 \mathrm{~h}$ in PLK-1 (Figure 3c). The aminopyrimidine moiety was still predicted to bind to the hinge region including Cys133, but a shift in the core was observed. Additionally, the core of the molecule adopts a more strained, puckered conformation. Both differences from the observed binding mode were likely caused by clashes of the bromobenzyl group with the side chain of Phe183 and were consistent with the decrease in activity observed with benzyl analogues $\mathbf{1 6} \mathbf{f}-\mathbf{i}$. We thus decided to explore if this key amino acid difference can be exploited to discover compounds with improved ALK potency and PLK-1 selectivity.

To enable structure-based design, we attempted to solve cocrystal structures of our compounds bound to ALK. However, these attempts failed, likely due to the still modest activity. Due to the lack of structural information, we decided to probe the ALK pocket through systematic synthesis and testing.

Using the modified route in Scheme 3 to facilitate preparation of analogues at the $\mathrm{R}^{2}$ position, we prepared compounds $23 a-c$ to analyze the effect of different substitutions at the 3-benzyl position. While these compounds maintained the BRD4 activity, we did not observe improvements in $\mathrm{ALK}^{\mathrm{F} 1174 \mathrm{~L}}$ potency or PLK-1 selectivity, aside from compound 23b that contains a 3-cyanobenzyl group. The PLK-1 IC 50 was $1.8 \mu \mathrm{M}$, a $>700$-fold decrease from starting compound BI-2536, leading to an improved (5-fold) ALK selectivity over PLK-1. Compound 23b demonstrated that PLK-1 activity can be substantially reduced by varying this position, but we were still yet to find a group that achieved this while maintaining or improving $\mathrm{ALK}^{\mathrm{F} 1174 \mathrm{~L}}$ potency. Next, we considered changing the substitution position on the benzyl ring. However, the ortho- and para-bromobenzyls $23 \mathrm{~d}$ and $23 \mathbf{e}$ showed no improvement in $\mathrm{ALK}^{\mathrm{F} 1174 \mathrm{~L}}$ potency compared with meta-analogue $16 \mathrm{~h}$ and were still not as potent as unsubstituted benzyl analogue 16i.

We then considered heterocycle substituents. Thiazole $\mathbf{2 3 f}$ showed a decrease in $\mathrm{ALK}^{\mathrm{F} 1174 \mathrm{~L}}$ activity, but exploring thiophenes proved to be more productive. Compound 16j gave encouraging $\mathrm{IC}_{50} \mathrm{~s}$ against $\mathrm{ALK} \mathrm{F}^{\mathrm{F} 1174 \mathrm{~L}}$ and $\mathrm{BRD} 4$, yet the ALK/PLK ratio dropped to 1:1. Following from this result, we moved the methyl group around the thiophene ring. Derivative 16k with the methyl group at the 4-position showed potent inhibition of $\mathrm{ALK}^{\mathrm{F} 1174 \mathrm{~L}}\left(\mathrm{IC}_{50}=17 \mathrm{nM}\right)$ and through this gain in potency also a 7-fold selectivity window over PLK-1. Gratifyingly, the compound retained BRD4 activity (Table 2).

We next determined the cocrystal structures of $16 \mathbf{i}$ and $16 \mathbf{k}$ with BRD4 (Figure 4 and Supp. Table 3). The compounds bound into the acetyllysine-binding site with the methyl amide moiety retaining the key hydrogen bond interaction with asparagine N140. The methyl amide and pyrimidine moieties in both compounds retain interactions with conserved waters in the BRD4 pocket, whereas the thiophene and benzyl $\mathrm{R}^{2}$ substituents are situated in the hydrophobic WPF shelf region.

With compound $16 \mathrm{k}$, we had a compound in hand that showed satisfactory $\mathrm{IC}_{50}$ s against $\mathrm{ALK}^{\mathrm{F} 1174 \mathrm{~L}}$ and BRD4 and a selectivity window over PLK-1. We decided to profile $\mathbf{1 6 k}$ further by examining the physicochemical properties and broader kinase and bromodomain selectivity. Lipophilicity was measured using the SiriusT3 potentiometric method, giving a high $\log P$ of 6.1 (Table 3 ). It is notable that the measured log $D_{7.4}$ of 4.2 is significantly lower due to protonation of the piperidine basic center, which can also account for the good solubility. In addition, the compound shows good permeability as measured in a PAMPA permeability assay.

Next, we considered the broader kinase and bromodomain selectivity of $16 \mathbf{k}$ to assess if the compound maintained the selectivity across both protein families. Compound 16k was first tested against a panel of BET and non-BET bromodomains. In this panel, 16 k exhibited excellent BET family selectivity, in common with BI-2536 and other BET inhibitors (Figure 5a and Supp. Table 4). ${ }^{14,33,34}$ We then tested 16k against the DiscoverX scanEDGE panel of 97 kinases at a single point concentration of $1 \mu \mathrm{M} .{ }^{35}$ Gratifyingly, only four kinases were identified as hits, confirming that we had maintained broad kinome selectivity; the greatest inhibition was observed for ALK wild type (WT) and PLK-1 
Table 2. Structure-Activity Relationships of the $\mathbf{R}^{2}$ Group $^{c}$<smiles>[R]N1c2nc(Nc3ccc(C4CCN(C)CC4)cc3OCC)ncc2N(C)C(=O)C1CC</smiles>

\begin{tabular}{|c|c|c|c|c|c|}
\hline No. & $\mathrm{R}^{2}$ & $\underset{(\mathrm{nM})^{\mathrm{a}}}{\mathrm{ALK}^{\mathrm{F} 1174 \mathrm{~L}} \mathrm{IC}_{50}}$ & $\begin{array}{l}\text { BRD4 } T_{m} \\
\text { Shift }(K)^{a, b}\end{array}$ & $\begin{array}{l}\text { BRD4 K } \\
\text { (nM) }\end{array}$ & $\begin{array}{l}\text { PLK-1 IC } \\
\quad(\mathrm{nM})^{\mathrm{a}}\end{array}$ \\
\hline $16 \mathbf{i}$ & $\mathrm{Bn}$ & 85 & 4.7 & 54 & 290 \\
\hline $16 \mathrm{~h}$ & 3-BrBn & 290 & 5.0 & 120 & 540 \\
\hline $23 a$ & $3-\mathrm{ClBn}$ & 210 & 6.2 & 130 & 540 \\
\hline $23 b$ & $3-\mathrm{CNBn}$ & 370 & 4.8 & 78 & 1800 \\
\hline $23 c$ & 3-OMeBn & 350 & 5.1 & n.d & n.d \\
\hline 23d & 2-BrBn & 150 & 2.9 & n.d & n.d \\
\hline $23 e$ & 4-BrBn & 680 & 5.8 & n.d & n.d \\
\hline $16 j^{b}$ & & 63 & 5.4 & 63 & 68 \\
\hline $16 k^{b}$ & & 17 & 7.1 & 44 & 125 \\
\hline $161^{\mathrm{b}}$ & & 220 & 8.3 & n.d & n.d \\
\hline $23 f$ & & 370 & 4.6 & n.d & n.d \\
\hline
\end{tabular}

${ }^{a}$ Data represents the geometric mean; see Supp. Table 2 for full statistics. n.d. $=$ not determined. ${ }^{b}$ Final compounds synthesized using Scheme 2 . ${ }^{c} T_{\mathrm{m}}$ shift determined at compound concentration of $10 \mu \mathrm{M}, n=2$.

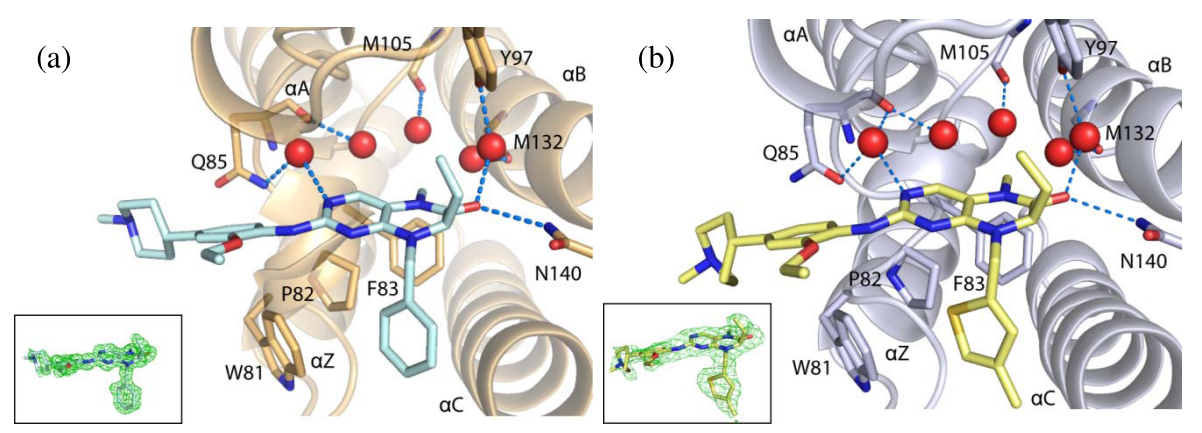

Figure 4. (a) Cocrystal structure of $\mathbf{1 6 i}$ with BRD4 (6Q3Y) and associated $\left|2 F_{\mathrm{O}}\right|-\left|F_{\mathrm{C}}\right|$ refined electron density map contoured at $1 \sigma$. (b) Cocrystal structure of $16 \mathrm{k}$ with BRD4 $(6 \mathrm{Q} 3 \mathrm{Z})$ and associated $\left|2 F_{\mathrm{O}}\right|-\left|F_{\mathrm{C}}\right|$ refined electron density map contoured at $1 \sigma$.

followed by insulin receptor (INSR) and PLK-3 (Figure 5b and Table 4). We attributed the observed broad kinase selectivity of $16 \mathrm{k}$ at least partially to be due to the ethoxy group. $^{21,27}$ This was based on the observation that the kinases that showed significant inhibition (ALK, PLK-1, PLK-3, and INSR) indeed feature a smaller leucine residue in the hinge 
Table 3. Physicochemical Properties of $16 \mathrm{k}$

\begin{tabular}{ll}
\multicolumn{1}{c}{ parameter } & \multicolumn{1}{c}{ result } \\
solubility $(\mathrm{HPLC})^{a}$ & $90 \mu \mathrm{M}$ \\
PAMPA $\mathrm{pH}_{7.4}$ & $49 \times 10^{-6} \mathrm{~cm} / \mathrm{s}$ \\
$\log P$ & 6.1 \\
$\log D_{7.4}$ & 4.2
\end{tabular}

${ }^{a}$ Solubility measured via an in-house HPLC method from phosphate buffer at $\mathrm{pH} 7.4$.
Table 4. $K_{d} s$ of $16 \mathrm{k}$ against the Kinase Screening Hits

\begin{tabular}{lcc} 
kinase & hits at $1 \mu \mathrm{M}(\%$ control $)$ & $K_{\mathrm{d}}(\mathrm{nM})$ \\
ALK WT & 7.1 & 89 \\
INSR & 25 & 190 \\
PLK-1 & 1 & 11 \\
PLK-3 & 25 & 160 \\
ALK & & 23 \\
\hline
\end{tabular}

region that can accommodate the ethoxy group (Supp. Table $5)$.

(a)

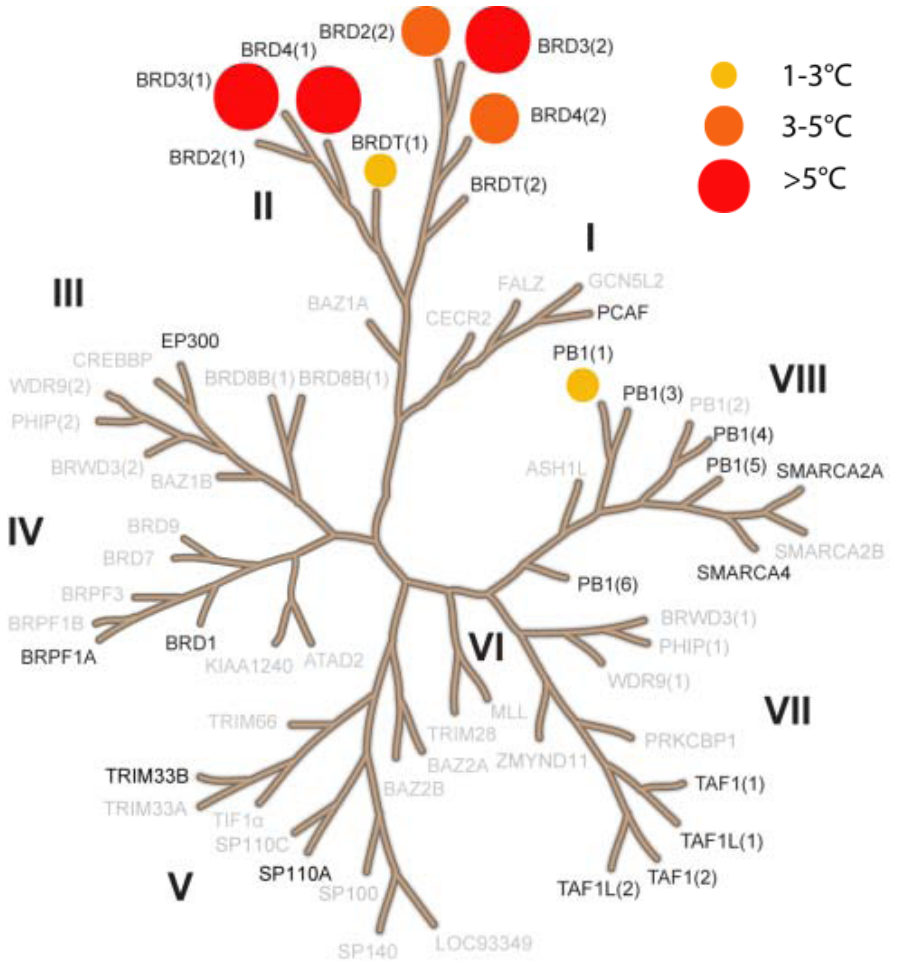

(b)

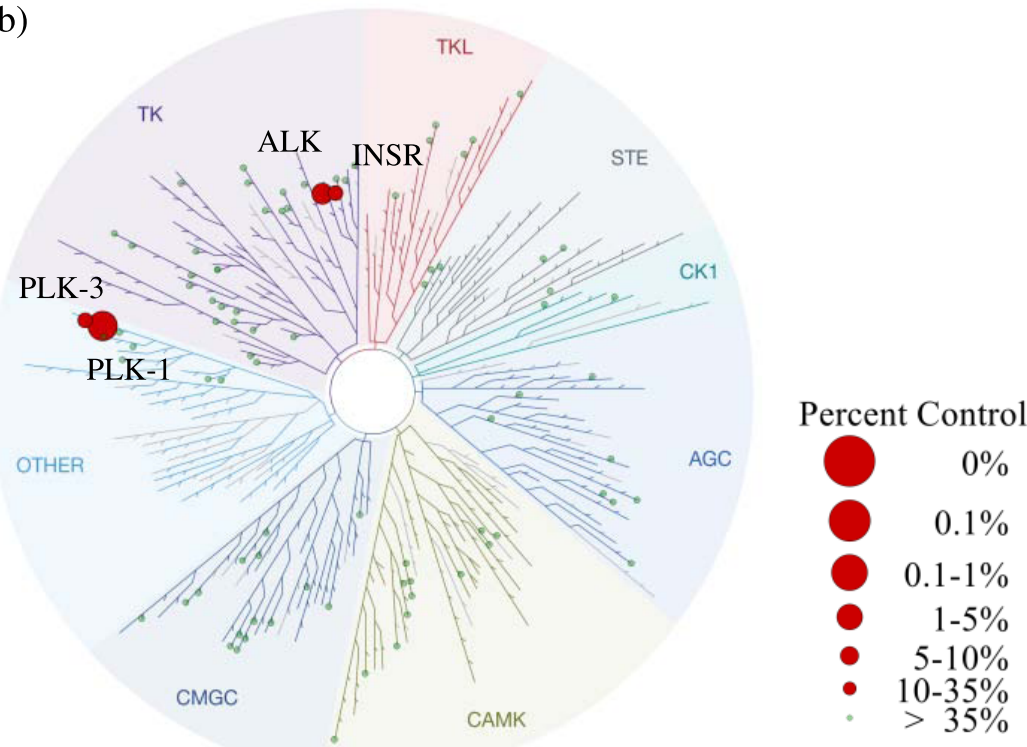

Figure 5. (a) Screening of 16k against a panel of 25 bromodomains, showing $\Delta T_{\mathrm{m}}$ as circles. Larger circles indicate greater $\Delta T_{\mathrm{m}}$. (b) Screening of 16k against the DiscoverX scanEDGE panel of 97 kinases at a single point concentration of $1 \mu \mathrm{M}$. Larger circles indicate a stronger hit. 


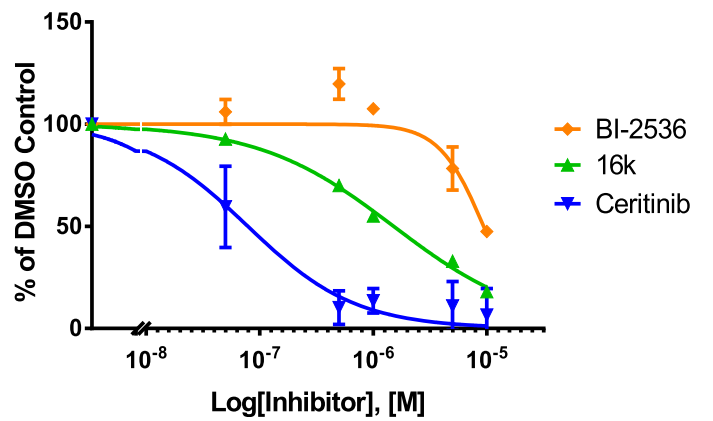

\begin{tabular}{cc} 
Compound & IC $_{50}$ \\
\hline BI-2536 & $>9.4 \mu \mathrm{M}$ \\
$16 \mathrm{k}$ & $1.5 \mu \mathrm{M}$ \\
Ceritinib & $79 \mathrm{nM}$
\end{tabular}

Figure 6. ALK MSD immunoassay measuring ALK phosphorylation in the Kelly cell line. The plot shows the ratio of phosphorylated ALK to total ALK.

\begin{tabular}{ccc} 
Compound & $\begin{array}{c}\text { BRD4 IC }_{50} \\
(\boldsymbol{\mu M})\end{array}$ & $\begin{array}{c}\text { ALK IC } \\
(\boldsymbol{\mu M} \mathbf{5 0}\end{array}$ \\
\hline $\mathrm{BI}-2536$ & 0.30 & 0.89 \\
$16 \mathrm{i}$ & 0.54 & 1.64 \\
$16 \mathrm{j}$ & 0.31 & 1.02 \\
$16 \mathrm{k}$ & 0.26 & 0.47
\end{tabular}
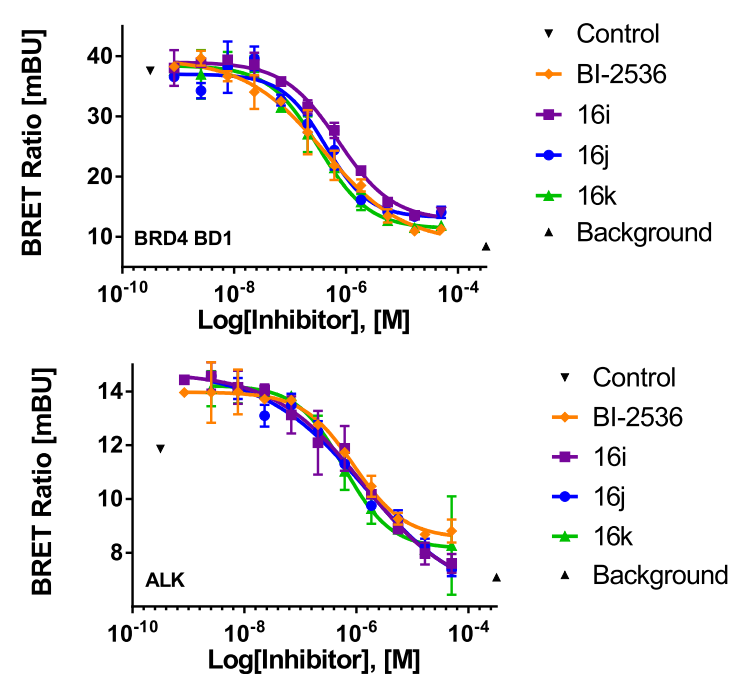

Figure 7. NanoBRET data for lead compounds 16i-k against ALK and BRD4 in HEK293T cells.

Demonstrating Target Engagement in Cells. We next tested our lead compounds in the cellular context to confirm that we had on-target engagement of ALK and BRD4 in cells. We first tested the effect of compound 16k on autophosphorylation of the $\mathrm{ALK}^{\mathrm{F} 1174 \mathrm{~L}}$ mutant in Kelly neuroblastoma cells using an meso-scale discovery (MSD) assay (Figure 6). For comparison, we also tested our starting point BI-2536 and the Food and Drug Administration-approved ALK inhibitor ceritinib $^{26}$ as a positive control. Compound $16 \mathbf{k}$ showed inhibition of $\mathrm{ALK}^{\mathrm{F} 1174 \mathrm{~L}}$ phosphorylation levels, in line with what was expected from the biochemical $\mathrm{IC}_{50}$ and representing a significant improvement from starting compound BI-2536.

We also measured the cellular potency of our lead compounds against BRD4 and ALK WT using NanoBRET assays (Figure 7 and Supp. Table 6). Compound 16k showed a cellular potency of $470 \mathrm{nM}$ against ALK WT and $260 \mathrm{nM}$ against BRD4. The BRD4 cellular potency was comparable to that of starting compound BI-2536, consistent with the compound's minimal disruption to the key interactions with the BRD4 pocket. The results of the ALK autophosphorylation assay and NanoBRET experiments demonstrated that 16k inhibited both $\mathrm{ALK}^{\mathrm{F1174L}}$ and BRD4 in cells.

Cellular Kinase Selectivity. The observation that the biochemical potency of $16 \mathbf{k}$ translated efficiently into cellular assays with a relatively minor drop-off consistent with other ALK inhibitors prompted us to investigate the selectivity against PLK-1 in cells. Despite very good overall selectivity in the DiscoverX scan, 16k showed similar $K_{d}$ s for the $A_{L K}{ }^{F 1174 L}$ mutant and PLK-1 (23 vs $11 \mathrm{nM}$, Table 4). However, given the small cellular drop-off for ALK mentioned above, we speculated that a larger drop-off for PLK-1 may lead to a better selectivity window. To investigate this hypothesis, we investigated markers of PLK-1 inhibition in cells, namely, mitotic arrest in the G2/M phase and increased concentrations of PLK-1, cyclin B1, and phosphohistone H3. Indeed, BI-2536 has been published to show effects on these markers at concentration around $50 \mathrm{nM}$, which is a 250-fold drop-off from its $K_{\mathrm{d}}$ of $0.19 \mathrm{nM} \cdot{ }^{36}$ As compound $16 \mathrm{k}$ is structurally similar to BI-2536, we would expect to see a similar potency drop-off in cells, in this case to $>2.5 \mu \mathrm{M}$. To assess the cellular selectivity, we assessed the effect of compounds $16 \mathbf{k}$ and BI-2536 on HeLa cells. Consistent with data mentioned above, BI-2536 induced mitotic arrest and increased concentrations of PLK-1, cyclin $\mathrm{B} 1$, and phosphohistone $\mathrm{H} 3$ at a concentration as low as $50 \mathrm{nM}$ (Figure 8). ${ }^{36}$ In addition, we observed an increase in PLK-1 phosphorylation at sites T210 and S137. In strong contrast, compound 16 k did not cause an increase in levels of these mitotic markers and phosphorylation sites up to concentrations of $10 \mu \mathrm{M}$ and thus well beyond the concentration where $\mathrm{ALK}^{\mathrm{F} 1174 \mathrm{~L}}$ and $\mathrm{BRD} 4$ are inhibited in the cellular context. Quantitative analysis of the cell cycle distribution by flow cytometry supported the data obtained by Western blot analysis (Supp. Figure 2).

Based on the cellular data, the combination of the reduction in PLK-1 activity and the improvement in $\mathrm{ALK}^{\mathrm{F} 1174 \mathrm{~L}}$ activity thus resulted in a $>10-20$-fold selectivity window for $\mathrm{ALK}^{\mathrm{F} 1174 \mathrm{~L}}$ over PLK-1 in cells. Compound 16k thus 


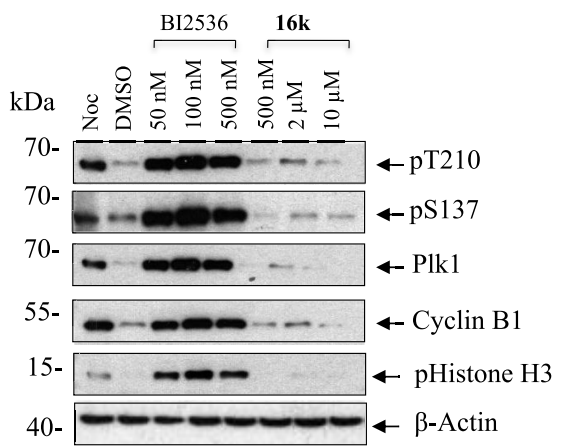

Figure 8. Induction of mitotic arrest by BI-2536 and 16k in HeLa cells. Changes in the fraction of cells arrested in mitosis were analyzed by Western blots against phosphorylation sites pT210 and pS137 and mitotic markers PLK-1, cyclin B1, and phosphohistone H3.

represented a significant step toward discovering drugs that concomitantly target mutant ALK and BRD4.

\section{CONCLUSIONS}

To our knowledge, we report the first combined ALK-BRD4 inhibitor (16k). Moreover, our work is one of the few examples where medicinal chemistry design was applied to combine inhibition of a specific kinase (in this case ALK) with BRD4 inhibition to discover a dual inhibitor for a clearly defined therapeutic hypothesis.

We started from the known dual inhibitor BI-2536 that inhibits PLK-1 and BRD4. Interestingly, although tuning the PLK-1 and BRD4 activity of BI-2536 has been disclosed, changing the kinase activity to another target and hence to a new dual kinase-bromodomain combination has not been reported. ${ }^{24,25}$ Exploring a structure-based design, we discovered compounds with significantly improved ALK activity and greatly reduced PLK-1 activity while maintaining BRD4 potency and overall kinome selectivity. Our lead compound demonstrates on-target engagement of ALK and BRD4 in cellular assays and favorable broad kinase and bromodomain selectivity. In particular, the compound showed selectivity over PLK-1 in cells underlining the design effort to change the kinase selectivity from PLK-1 to ALK.

Our work also highlighted the well-known challenges of designing and discovering dual inhibitors that inhibit two, structurally distinct proteins. A particular challenge is to incorporate two distinct pharmacophores that ensure not only potent inhibition of both targets but also selectivity within these protein families (in our case, kinases and bromodomains) into one druglike compound.

Despite these challenges, we achieved significant steps toward a dual ALK and BRD4 inhibitor. Key to this progress was choosing a starting point that contained an alkoxy group that is tolerated only by a few kinases including ALK and PLK1. By maintaining this throughout, we achieved a compound with satisfactory overall kinome selectivity.

Our main optimization goal starting from BI-2536 was to significantly improve ALK activity and PLK-1 selectivity. The challenge here was that key regions of BI-2536 had to remain untouched to maintain the BRD4 activity. In particular, the methyl substituent that points toward the gatekeeper and the ethyl group would have been promising places to improve activity for ALK and selectivity over PLK-1. However, both moieties are essential for potent binding to BRD4 and could hence not be changed. Crucially, our structure-based analysis also suggested that the $\mathrm{R}^{2}$ substituent can be modified without losing BRD4 activity and that optimizing this part of the molecule was a promising approach to achieve our goal of shifting kinase selectivity, as exemplified by $\mathbf{1 6 k}$.

We thus conclude that, not surprisingly, the quality and properties of the selected starting point matter even more for programs aiming at dual inhibitors since the options for chemical optimization will be significantly more limited. Directly related to that, the challenge of discovering dual inhibitors is somewhat less daunting when both targets tolerated a range of different chemotypes and inhibitors, thus increasing the chance that a starting point with already favorable properties can be explored.

\section{EXPERIMENTAL SECTION}

General Synthetic Information. All anhydrous solvents and reagents were obtained from commercial suppliers and used without further purification. All reactions were carried out under a positive pressure of $\mathrm{N}_{2}$, and moisture-sensitive reagents were transferred via a syringe. Evaporation of solvent was carried out using a rotary evaporator under reduced pressure at a bath temperature of up to 60 ${ }^{\circ} \mathrm{C}$. Column chromatography was carried out using a Biotage SP4 purification system using Biotage SNAP Kp-Si cartridges. Semipreparative separations were carried out using a 1200 series preparative HPLC over a 15 min gradient elution (Grad15min20mls.m) from 90:10 to 0:100 water/methanol (both modified with $0.1 \%$ formic acid) at a flow rate of $20 \mathrm{~mL} / \mathrm{min}$. Microwaveassisted reactions were carried out using a Biotage Initiator microwave system. In general, the course of reactions was followed by thin layer chromatography or mass spectroscopy. All final compounds were purified to $\geq 95 \%$ purity.

NMR spectra were recorded on a Bruker AMX $500(500 \mathrm{MHz})$ spectrometer using a deutrated solvent. NMR data is presented in the form of chemical shift $\delta$ (multiplicity, coupling constants, and integration) for major diagnostic protons, given in parts per million (ppm) relative to tetramethylsilane as an internal standard. Highresolution mass spectrometry (HRMS) was assessed using an Agilent 1200 series HPL and diode array detector coupled to a 6120 time-offlight mass spectrometer with a dual multimode atmospheric-pressure chemical ionization/electrospray ionization (ESI) source. Analytical separation was carried out at $30{ }^{\circ} \mathrm{C}$ on a Merck Purospher STAR column $\left(\mathrm{RP}-18 \mathrm{e}, 30 \times 4 \mathrm{~mm}^{2}\right)$ using a flow rate of $1.5 \mathrm{~mL} / \mathrm{min}$ in a 4 min gradient elution; solvents: aqueous $(0.1 \%$ formic aid $)$ and methanol, monitored at a wavelength of $254 \mathrm{~nm}$. Optical rotation was determined by an ADP 440 polarimeter. Specific rotations $[\alpha]_{\mathrm{D}}$ are given in $\operatorname{deg} \mathrm{cm}^{3} /(\mathrm{g} \mathrm{dm})$.

Methyl 3-Isobutoxy-4-nitrobenzoate (2). Step 1: 3-Hydroxy-4nitrobenzoic acid $1(500 \mathrm{mg}, 2.73 \mathrm{mmol})$ was suspended in $\mathrm{MeOH}$ $(0.1 \mathrm{M})$, and $\mathrm{SOCl}_{2}(0.40 \mathrm{~mL}, 5.46 \mathrm{mmol})$ was added slowly at $0{ }^{\circ} \mathrm{C}$. The reaction was heated at reflux for $4 \mathrm{~h}$. Upon completion, the volatiles were removed in vacuo and the residue was triturated with diethyl ether. The resulting solid was filtered and dried under vacuum to afford methyl 3-hydroxy-4-nitrobenzoate ( $\mathrm{HCl}$ salt) as a yellow solid (576 mg, 90\%). $\delta_{\mathrm{H}}\left(500 \mathrm{MHz}, \mathrm{CDCl}_{3}\right): 10.51(\mathrm{~s}, 1 \mathrm{H}), 8.18(\mathrm{~d}, J$ $=8.5 \mathrm{~Hz}, 1 \mathrm{H}), 7.84(\mathrm{~d}, J=1.6 \mathrm{~Hz}, 1 \mathrm{H}), 7.62(\mathrm{dd}, J=8.5,1.6 \mathrm{~Hz}$, $1 \mathrm{H}), 3.97(\mathrm{~s}, 3 \mathrm{H})$. Step 2: To the crude product in DMF $(0.1 \mathrm{M})$ was added $\mathrm{K}_{2} \mathrm{CO}_{3}(592 \mathrm{mg}, 4.28 \mathrm{mmol})$ and 1-iodo-2-methylpropane $(142 \mu \mathrm{L}, 1.20 \mathrm{mmol})$, and the reaction was stirred at $50{ }^{\circ} \mathrm{C}$ for $16 \mathrm{~h}$. Upon completion, EtOAc was added and the mixture was washed with water $(\times 2)$ and brine $(\times 1)$, dried over $\mathrm{MgSO} 4$, filtered, and concentrated in vacuo. The residue was purified by Biotage column chromatography (cHex/EtOAc, $0-20 \%$ ) to afford 2 as a colorless oil $(158 \mathrm{mg}, 0.62 \mathrm{mmol} 73 \%) . \delta_{\mathrm{H}}\left(500 \mathrm{MHz}, \mathrm{CDCl}_{3}\right): 7.81(\mathrm{~d}, J=8.2$ $\mathrm{Hz}, 1 \mathrm{H}), 7.71(\mathrm{~d}, J=1.6 \mathrm{~Hz}, 1 \mathrm{H}), 7.67-7.64(\mathrm{~m}, 1 \mathrm{H}), 3.96(\mathrm{~s}, 3 \mathrm{H})$, $3.92(\mathrm{~d}, J=6.3 \mathrm{~Hz}, 1 \mathrm{H}), 2.20-2.11(\mathrm{~m}, 1 \mathrm{H}), 1.05(\mathrm{~d}, J=6.9 \mathrm{~Hz}$, $6 \mathrm{H})$. 
3-Isobutoxy-4-nitrobenzoic Acid (3a). To 2 (150 mg, $0.59 \mathrm{mmol}$ ) in a solvent mixture of THF/ $\mathrm{H}_{2} \mathrm{O}(1: 1,0.1 \mathrm{M})$ was added $\mathrm{LiOH}(142$ $\mathrm{mg}, 5.92 \mathrm{mmol}$ ), and the reaction was stirred for $18 \mathrm{~h}$. Upon completion, the aqueous layer was acidified with $1 \mathrm{M} \mathrm{HCl} \mathrm{until} \mathrm{pH} 1$ was reached and extracted with EtOAc $(\times 3)$. The combined organic phases were dried over $\mathrm{MgSO}_{4}$, filtered, and concentrated in vacuo to afford 3a as a yellow solid $(100 \mathrm{mg}, 0.42 \mathrm{mmol}, 71 \%) . \delta_{\mathrm{H}}(500 \mathrm{MHz}$, $\left.\mathrm{CDCl}_{3}\right): 7.85(\mathrm{~d}, J=8.2 \mathrm{~Hz}, 1 \mathrm{H}), 7.79(\mathrm{~d}, J=1.3 \mathrm{~Hz}, 1 \mathrm{H}), 7.76(\mathrm{dd}, J$ $=8.2,1.3 \mathrm{~Hz}, 1 \mathrm{H}), 3.95(\mathrm{~d}, J=6.3 \mathrm{~Hz}, 1 \mathrm{H}), 2.23-2.14(\mathrm{~m}, 1 \mathrm{H}), 1.08$ $(\mathrm{d}, J=6.9 \mathrm{~Hz}, 6 \mathrm{H})$.

3-Isobutoxy-N-(1-methylpiperidin-4-yl)-4-nitrobenzamide (4a). To a solution of $3 \mathrm{a}(50 \mathrm{mg}, 0.21 \mathrm{mmol})$ in $\operatorname{DMF}(0.1 \mathrm{M})$ was added HBTU (127 mg, $0.33 \mathrm{mmol}), \mathrm{Et}_{3} \mathrm{~N}(58 \mu \mathrm{L}, 0.41 \mathrm{mmol})$, and 1methylpiperidin-4-amine $(23.9 \mathrm{mg}, 0.21 \mathrm{mmol})$, and the reaction was stirred for $18 \mathrm{~h}$. Upon completion, the reaction mixture was partitioned between EtOAc and water and the aqueous layer was extracted with EtOAc $(\times 2)$. The organic phases were combined, dried over $\mathrm{MgSO}_{4}$, filtered, and concentrated in vacuo. The residue was purified by Biotage column chromatography (dichloromethane $(\mathrm{DCM}) / \mathrm{MeOH}, 0-10 \%)$ to afford $4 \mathrm{a}$ as a yellow solid $(60 \mathrm{mg}$, $0.18 \mathrm{mmol}, 86 \%$ ). HRMS (ESI +ve): found $[\mathrm{M}]^{+}$336.1927, $\left[\mathrm{C}_{17} \mathrm{H}_{24} \mathrm{~N}_{3} \mathrm{O}_{4}\right]^{+}$requires $336.1923 ; \delta_{\mathrm{H}}\left(500 \mathrm{MHz}, \mathrm{CDCl}_{3}\right) 7.81(\mathrm{~d}$, $J=8.2 \mathrm{~Hz}, 1 \mathrm{H}), 7.55(\mathrm{~d}, J=1.6 \mathrm{~Hz}, 1 \mathrm{H}), 7.28(\mathrm{dd}, J=8.2,1.6 \mathrm{~Hz}$, $1 \mathrm{H}), 6.44(\mathrm{~d}, J=7.6 \mathrm{~Hz}, 1 \mathrm{H}), 4.06-3.97(\mathrm{~m}, 1 \mathrm{H}), 3.92(\mathrm{~d}, J=6.3$ $\mathrm{Hz}, 2 \mathrm{H}), 2.94(\mathrm{~d}, J=11.7 \mathrm{~Hz}, 2 \mathrm{H}), 2.37(\mathrm{~s}, 3 \mathrm{H}), 2.30-2.25(\mathrm{~m}, 2 \mathrm{H})$, $2.18-2.10(\mathrm{~m}, 1 \mathrm{H}), 2.09-2.03(\mathrm{~m}, 2 \mathrm{H}), 1.78-1.69(\mathrm{~m}, 2 \mathrm{H}), 1.04(\mathrm{~d}$, $J=6.6 \mathrm{~Hz}, 6 \mathrm{H})$.

3-Ethoxy-N-(1-methylpiperidin-4-yl)-4-nitrobenzamide (4b). 4b was synthesized in $77 \%$ yield (orange solid, $111 \mathrm{mg}, 0.36 \mathrm{mmol}$ ) according to the same procedure as $4 \mathbf{a}$, from $3 \mathbf{b}(100 \mathrm{mg}, 0.47 \mathrm{mmol})$ and 1-methylpiperidin-4-amine ( $54.1 \mathrm{mg}, 0.47 \mathrm{mmol}$ ). HRMS (ESI $+\mathrm{ve})$ : found $[\mathrm{M}]^{+} 308.1624\left[\mathrm{C}_{15} \mathrm{H}_{21} \mathrm{~N}_{3} \mathrm{O}_{4}\right]^{+}$requires 308.1610; $\delta_{\mathrm{H}}$ $\left(500 \mathrm{MHz}, \mathrm{CDCl}_{3}\right): 7.82(\mathrm{~d}, J=8.2 \mathrm{~Hz}, 1 \mathrm{H}), 7.58(\mathrm{~d}, J=1.9 \mathrm{~Hz}$, $1 \mathrm{H}), 7.23(\mathrm{dd}, J=8.2,1.9 \mathrm{~Hz}, 1 \mathrm{H}), 5.99(\mathrm{~d}, J=7.3 \mathrm{~Hz}, 1 \mathrm{H}), 4.26(\mathrm{q}$, $J=7.2 \mathrm{~Hz}, 2 \mathrm{H}), 4.05-3.94(\mathrm{~m}, 1 \mathrm{H}), 2.87(\mathrm{~d}, J=11.2 \mathrm{~Hz}, 2 \mathrm{H}), 2.33$ $(\mathrm{s}, 3 \mathrm{H}), 2.19(\mathrm{t}, J=11.2 \mathrm{~Hz}, 2 \mathrm{H}), 2.10-2.03(\mathrm{~m}, 2 \mathrm{H}), 1.65-1.56(\mathrm{~m}$, $2 \mathrm{H}), 1.49(\mathrm{t}, J=6.9 \mathrm{~Hz}, 3 \mathrm{H})$.

4-Amino-3-isobutoxy-N-(1-methylpiperidin-4-yl)benzamide (5a). $4 \mathrm{a}(60 \mathrm{mg}, 0.18 \mathrm{mmol})$ was dissolved in a solvent mixture of EtOAc/EtOH (10:3, 0.1 M) to which tin(II) chloride dihydrate (202 $\mathrm{mg}, 0.89 \mathrm{mmol}$ ) was added. The reaction was stirred for $16 \mathrm{~h}$ at 50 ${ }^{\circ} \mathrm{C}$. Upon completion, $\mathrm{NaHCO}_{3}$ was added and the aqueous layer was extracted with EtOAc $(\times 3)$. The combined organic phases were dried over $\mathrm{MgSO}_{4}$, filtered, and concentrated in vacuo to afford 5 a as a yellow solid (30 mg, $99 \mu \mathrm{mol}, 55 \%$ ). HRMS (ESI +ve): found $[\mathrm{M}]^{+}$ 306.22161, $\left[\mathrm{C}_{17} \mathrm{H}_{28} \mathrm{~N}_{3} \mathrm{O}_{2}\right]^{+}$requires $306.2176 ; \delta_{\mathrm{H}}\left(500 \mathrm{MHz}, \mathrm{CDCl}_{3}\right)$ $7.32(\mathrm{~d}, J=1.9 \mathrm{~Hz}, 1 \mathrm{H}), 7.10(\mathrm{~d}, J=8.2,1.9 \mathrm{~Hz}, 1 \mathrm{H}), 6.66(\mathrm{~d}, J=8.2$ $\mathrm{Hz}, 1 \mathrm{H}), 5.86(\mathrm{~d}, J=6.3 \mathrm{~Hz}, 1 \mathrm{H}), 4.12(\mathrm{~s}, 2 \mathrm{H}), 4.02-3.92(\mathrm{~m}, 1 \mathrm{H})$, $3.83(\mathrm{~d}, J=6.3 \mathrm{~Hz}, 2 \mathrm{H}), 2.83(\mathrm{~d}, J=11.0 \mathrm{~Hz}, 2 \mathrm{H}), 2.31(\mathrm{~s}, 3 \mathrm{H})$, $2.22-2.09(\mathrm{~m}, 3 \mathrm{H}), 2.07-2.00(\mathrm{~m}, 2 \mathrm{H}), 1.57(\mathrm{qd}, J=11.7,3.6 \mathrm{~Hz}$, $2 \mathrm{H}), 1.04(\mathrm{~d}, J=6.9 \mathrm{~Hz}, 6 \mathrm{H})$.

4-Amino-3-ethoxy-N-(1-methylpiperidin-4-yl)benzamide (5b). $5 \mathbf{b}$ was synthesized in $53 \%$ yield (yellow solid, $46 \mathrm{mg}, 0.16 \mathrm{mmol}$ ) according to the same procedure as $\mathbf{5 a}$, from $\mathbf{4 b}(95 \mathrm{mg}, 0.31 \mathrm{mmol})$. HRMS (ESI +ve): found $[\mathrm{M}]^{+} 278.1874\left[\mathrm{C}_{15} \mathrm{H}_{23} \mathrm{~N}_{3} \mathrm{O}_{2}\right]^{+}$requires $278.1863 ; \delta_{\mathrm{H}}\left(500 \mathrm{MHz}, \mathrm{CDCl}_{3}\right) 7.33(\mathrm{~d}, J=1.9 \mathrm{~Hz}, 1 \mathrm{H}), 7.11(\mathrm{dd}, J$ $=8.1,1.9 \mathrm{~Hz}, 1 \mathrm{H}), 6.66(\mathrm{~d}, J=8.1 \mathrm{~Hz}, 1 \mathrm{H}), 5.86(\mathrm{~d}, J=7.3 \mathrm{~Hz}, 1 \mathrm{H})$, $4.18-4.09(\mathrm{~m}, 4 \mathrm{H}), 4.05-3.94(\mathrm{~m}, 1 \mathrm{H}), 2.86(\mathrm{~d}, J=11.0 \mathrm{~Hz}, 2 \mathrm{H})$, $2.33(\mathrm{~s}, 3 \mathrm{H}), 2.23-2.18(\mathrm{~m}, 2 \mathrm{H}), 2.04(\mathrm{~d}, J=10.4 \mathrm{~Hz}, 2 \mathrm{H}), 1.61-$ $1.57(\mathrm{~m}, 2 \mathrm{H}), 1.45(\mathrm{t}, J=6.9 \mathrm{~Hz}, 3 \mathrm{H})$.

4-(3-Ethoxy-4-nitrophenyl)pyridine (7a). 4-Bromo-2-ethoxy-1-nitrobenzene $6 \mathrm{a}(1.5 \mathrm{~g}, 6.10 \mathrm{mmol})$, pyridine-4-ylboronic acid $(749 \mathrm{mg}$, $6.10 \mathrm{mmol}), \mathrm{Na}_{2} \mathrm{CO}_{3}(1.1 \mathrm{~g}, 10.0 \mathrm{mmol})$, and $\mathrm{Pd}\left(\mathrm{PPh}_{3}\right)_{2} \mathrm{Cl}_{2}(160 \mathrm{mg}$, $0.23 \mathrm{mmol})$ were dissolved in a solvent mixture of dioxane/water $(6: 1,0.38 \mathrm{M})$ and heated at $110{ }^{\circ} \mathrm{C}$ for $45 \mathrm{~min}$ under microwave irradiation. Upon completion, the mixture was partitioned between EtOAc and water and the aqueous phase was extracted with EtOAc $(\times 2)$ and DCM $(\times 1)$. The organic phases were combined, dried over $\mathrm{MgSO}_{4}$, filtered, and concentrated in vacuo. The residue was purified by Biotage column chromatography (DCM/MeOH, 9:1) to afford 7a as a yellow solid ( $81 \mathrm{mg}, 3.32 \mathrm{mmol}, 54 \%)$. HRMS (ESI +ve): found $[\mathrm{M}]^{+} 245.0917\left[\mathrm{C}_{13} \mathrm{H}_{12} \mathrm{~N}_{2} \mathrm{O}_{3}\right]^{+}$requires $245.0921 ; \delta_{\mathrm{H}}(500 \mathrm{MHz}$, $\left.\mathrm{CDCl}_{3}\right): 8.74(\mathrm{dd}, J=4.4,1.19 \mathrm{~Hz}, 2 \mathrm{H}), 7.96(\mathrm{~d}, J=8.5 \mathrm{~Hz}, 1 \mathrm{H})$, 7.49 (d, $J=4.4,1.6 \mathrm{~Hz}, 2 \mathrm{H}), 7.27-7.24(\mathrm{~m}, 2 \mathrm{H}), 4.28(\mathrm{q}, J=7.0 \mathrm{~Hz}$, $2 \mathrm{H}), 1.53(\mathrm{dt}, J=7.0 \mathrm{~Hz}, 3 \mathrm{H})$

4-(3-Methoxy-4-nitrophenyl)pyridine (7b). $7 \mathrm{~b}$ was synthesized in $65 \%$ yield (yellow solid, $200 \mathrm{mg}, 0.87 \mathrm{mmol}$ ) according to the same procedure as $7 \mathbf{a}$, from 4-chloro-2-methoxy-1-nitrobenzene $6 \mathbf{b}(250 \mathrm{~g}$, $1.33 \mathrm{mmol}$ ) and pyridine-4-ylboronic acid $(164 \mathrm{mg}, 1.33 \mathrm{mmol})$. HRMS (ESI +ve): found $[\mathrm{M}]^{+} 231.0803\left[\mathrm{C}_{12} \mathrm{H}_{10} \mathrm{~N}_{2} \mathrm{O}_{3}\right]^{+}$requires 231.0770; $\delta_{\mathrm{H}}\left(500 \mathrm{MHz}, \mathrm{CDCl}_{3}\right): 8.74-8.72(\mathrm{dd}, J=4.4,1.6 \mathrm{~Hz}$, $2 \mathrm{H}), 7.99(\mathrm{dd}, J=8.8 \mathrm{~Hz}, 1 \mathrm{H}), 7.51(\mathrm{dd}, J=4.4,1.6 \mathrm{~Hz}, 2 \mathrm{H}), 7.28-$ $7.25(\mathrm{~m}, 2 \mathrm{H}), 4.05(\mathrm{~s}, 3 \mathrm{H})$.

4-(3-Ethoxy-4-nitrophenyl)-1-methylpyridin 1-ium lodide (8a). 7a $(600 \mathrm{mg}, 2.47 \mathrm{mmol})$ and methyl iodide $(0.54 \mathrm{~mL}, 8.65 \mathrm{mmol})$ were dissolved in acetonitrile $(0.1 \mathrm{M})$, and the reaction was heated for $4 \mathrm{~h}$ at $50{ }^{\circ} \mathrm{C}$. Upon completion, the mixture was concentrated in vacuo to afford 8a as a yellow solid (945 mg, $2.45 \mathrm{mmol}$, 99\%). HRMS (ESI $+v e)$ found $[\mathrm{M}]^{+} 259.1076\left[\mathrm{C}_{14} \mathrm{H}_{15} \mathrm{~N}_{2} \mathrm{O}_{3}\right]^{+}$requires $259.1082 ; \delta_{\mathrm{H}}$ $\left(500 \mathrm{MHz}, \mathrm{MeOD}_{4}\right) 8.99(\mathrm{~d}, J=6.7 \mathrm{~Hz}, 2 \mathrm{H}), 8.48(\mathrm{~d}, J=6.7 \mathrm{~Hz}$, $2 \mathrm{H}), 7.99(\mathrm{~d}, J=8.5 \mathrm{~Hz}, 1 \mathrm{H}), 7.79(\mathrm{~d}, J=1.8 \mathrm{~Hz}, 1 \mathrm{H}), 7.65(\mathrm{dd}, J=$ $8.5,1.8 \mathrm{~Hz}, 1 \mathrm{H}), 4.46(\mathrm{~s}, 3 \mathrm{H}), 4.38(\mathrm{q}, J=6.9 \mathrm{~Hz}, 2 \mathrm{H}), 1.49(\mathrm{t}, J=$ $6.9 \mathrm{~Hz}, 3 \mathrm{H})$.

4-(3-Methoxy-4-nitrophenyl)-1-methylpyridin1-ium lodide (8b). $8 \mathbf{b}$ was synthesized in $91 \%$ yield (yellow solid, $295 \mathrm{mg}, 0.79 \mathrm{mmol}$ ) according to the same procedure as $8 \mathbf{a}$, from $7 \mathbf{b}(200 \mathrm{mg}, 0.87 \mathrm{mmol})$ and methyl iodide $(0.19 \mathrm{~mL}, 3.04 \mathrm{mmol})$. HRMS (ESI +ve): found $[\mathrm{M}]^{+} 245.0920\left[\mathrm{C}_{13} \mathrm{H}_{13} \mathrm{~N}_{2} \mathrm{O}_{3}\right]^{+}$requires 245.0926; $\delta_{\mathrm{H}}(500 \mathrm{MHz}$, $\left.\mathrm{MeOD}_{4}\right) 8.99(\mathrm{~d}, J=6.7 \mathrm{~Hz}, 2 \mathrm{H}), 8.49(\mathrm{~d}, J=6.7 \mathrm{~Hz}, 2 \mathrm{H}), 8.01(\mathrm{~d}, J$ $=8.2 \mathrm{~Hz}, 1 \mathrm{H}), 7.81(\mathrm{~d}, J=1.9 \mathrm{~Hz}, 1 \mathrm{H}), 7.66(\mathrm{dd}, J=8.2,1.9 \mathrm{~Hz}$, $1 \mathrm{H}), 4.45(\mathrm{~s}, 3 \mathrm{H}), 4.10(\mathrm{~s}, 3 \mathrm{H})$.

4-(3-Ethoxy-4-nitrophenyl)-1-methyl-1,2,3,6-tetrahydropyridine (9a). 8a (945 mg, $2.45 \mathrm{mmol}$ ) was dissolved in $\mathrm{MeOH}(0.05 \mathrm{M})$ and cooled to $0{ }^{\circ} \mathrm{C}$. $\mathrm{NaBH}_{4}(943 \mathrm{mg}, 24.5 \mathrm{mmol})$ was slowly added in batches, and the reaction was stirred at $\mathrm{rt}$ for $2 \mathrm{~h}$. The reaction was quenched with $1 \mathrm{M} \mathrm{HCl}$, and $\mathrm{MeOH}$ was partially removed in vacuo. The residue was partitioned between EtOAc and $1 \mathrm{M} \mathrm{NaOH}$ until $\mathrm{pH}$ 12 was reached. The EtOAc layer was washed with $1 \mathrm{M} \mathrm{NaOH}$, dried over $\mathrm{MgSO}_{4}$, filtered, and concentrated in vacuo to give $9 \mathrm{a}$ as a yellow oil (609 mg, $2.32 \mathrm{mmol}, 95 \%)$. HRMS (ESI +ve): found $[\mathrm{M}]^{+}$ $263.1387\left[\mathrm{C}_{14} \mathrm{H}_{18} \mathrm{~N}_{2} \mathrm{O}_{3}\right]^{+}$requires $263.1390 ; \delta_{\mathrm{H}}\left(500 \mathrm{MHz}, \mathrm{CDCl}_{3}\right)$ : $7.85(\mathrm{~d}, J=8.5 \mathrm{~Hz}, 1 \mathrm{H}), 7.04-7.00(\mathrm{~m}, 2 \mathrm{H}), 6.21-6.18(\mathrm{~m}, 1 \mathrm{H})$, $4.20(\mathrm{q}, J=6.9 \mathrm{~Hz}, 2 \mathrm{H}), 3.17-3.14(\mathrm{~m}, 2 \mathrm{H}), 2.69(\mathrm{t}, J=5.7 \mathrm{~Hz}, 2 \mathrm{H})$, $2.60-2.56(\mathrm{~m}, 2 \mathrm{H}), 2.43(\mathrm{~s}, 3 \mathrm{H}), 1.49(\mathrm{t}, J=6.9 \mathrm{~Hz}, 3 \mathrm{H})$.

4-(3-Methoxy-4-nitrophenyl)-1-methyl-1,2,3,6-tetrahydropyridine (9b). $9 \mathrm{~b}$ was synthesized in $56 \%$ yield (yellow oil, $80 \mathrm{mg}, 0.32$ $\mathrm{mmol})$ according to the same procedure as $9 \mathbf{a}$, from $8 \mathbf{b}(212 \mathrm{mg}, 0.57$ mmol). HRMS (ESI +ve): found $[\mathrm{M}]^{+} 245.1239\left[\mathrm{C}_{13} \mathrm{H}_{13} \mathrm{~N}_{2} \mathrm{O}_{3}\right]^{+}$ requires 249.1243; $\delta_{\mathrm{H}}\left(500 \mathrm{MHz}, \mathrm{CDCl}_{3}\right): 7.85(\mathrm{~d}, J=8.5 \mathrm{~Hz}, 1 \mathrm{H})$, $7.04(\mathrm{~d}, J=1.9 \mathrm{~Hz}, 1 \mathrm{H}), 7.02(\mathrm{dd}, J=8.5,1.9 \mathrm{~Hz}, 1 \mathrm{H}), 6.20(\mathrm{tt}, J=$ $3.5,1.6 \mathrm{~Hz}, 1 \mathrm{H}), 3.96(\mathrm{~s}, 3 \mathrm{H}), 3.16(\mathrm{~d}, J=2.85 \mathrm{~Hz}, 2 \mathrm{H}), 2.71-2.67$ (m, $2 \mathrm{H}), 2.60-2.56(\mathrm{~m}, 2 \mathrm{H}), 2.42(\mathrm{~s}, 3 \mathrm{H})$.

2-Ethoxy-4-(1-methylpiperidin-4-yl)aniline (10a). 9a (600 mg, $2.32 \mathrm{mmol})$ and $\mathrm{PtO}_{2}(158 \mathrm{mg}, 0.70 \mathrm{mmol})$ were dissolved in acetic acid $(0.03 \mathrm{M})$, and the mixture was purged with $\mathrm{N}_{2}$. The mixture was placed under $50 \mathrm{psi}$ of $\mathrm{H}_{2}$ gas at rt for $16 \mathrm{~h}$. The mixture was filtered through celite, washed with $\mathrm{MeOH}$, and concentrated in vacuo. The residue was purified by Biotage column chromatography (DCM/ $\mathrm{MeOH}, 9: 1)$ to afford 10a as an orange oil $(410 \mathrm{mg}, 1.75 \mathrm{mmol}$, $75 \%)$. HRMS (ESI +ve): found $[\mathrm{M}]^{+} 235.1819\left[\mathrm{C}_{14} \mathrm{H}_{22} \mathrm{~N}_{2} \mathrm{O}\right]^{+}$ requires $235.1809 ; \delta_{\mathrm{H}}\left(500 \mathrm{MHz}, \mathrm{CDCl}_{3}\right) 6.68-6.60(\mathrm{~m}, 3 \mathrm{H}), 4.05$ $(\mathrm{q}, J=7.0 \mathrm{~Hz}, 2 \mathrm{H}), 3.20(\mathrm{~d}, J=11.7 \mathrm{~Hz}, 2 \mathrm{H}), 2.46-2.38(4 \mathrm{H}, \mathrm{m})$ $2.29(\mathrm{td}, J=11.7,2.5 \mathrm{~Hz}, 2 \mathrm{H}), 1.99-1.89(\mathrm{~m}, 2 \mathrm{H}), 1.88-1.82(\mathrm{~m}$, $2 \mathrm{H}), 1.42(\mathrm{t}, J=7.0 \mathrm{~Hz}, 3 \mathrm{H})$.

2-Methoxy-4-(1-methylpiperidin-4-yl)aniline (10b). 10b was synthesized in $85 \%$ yield (yellow oil, $30 \mathrm{mg}, 0.14 \mathrm{mmol}$ ) according to the same procedure as $10 \mathrm{a}$, from $9 \mathbf{b}(600 \mathrm{mg}, 2.32 \mathrm{mmol})$. HRMS $(\mathrm{ESI}+\mathrm{ve})$ : found $[\mathrm{M}]^{+} 221.1649\left[\mathrm{C}_{13} \mathrm{H}_{20} \mathrm{~N}_{2} \mathrm{O}\right]^{+}$requires 221.1648; $\delta_{\mathrm{H}}\left(500 \mathrm{MHz}, \mathrm{CDCl}_{3}\right) 6.65-6.61(\mathrm{~m}, 3 \mathrm{H}), 3.83(\mathrm{~s}, 3 \mathrm{H}), 3.08(\mathrm{dt}, J=$ 
12.1, $2.5 \mathrm{~Hz}, 2 \mathrm{H}), 2.46-2.37(\mathrm{~m}, 1 \mathrm{H}), 2.38(\mathrm{~s}, 3 \mathrm{H}), 2.16(\mathrm{td}, J=$ 12.1, $4.1 \mathrm{~Hz}, 2 \mathrm{H}), 1.91-1.81(\mathrm{~m}, 4 \mathrm{H})$.

(R)-Methyl 2-(Cyclopentylamino)butanoate (12a). (R)-Methyl 2aminobutanoate 11a ( $\mathrm{HCl}$ salt, $1.50 \mathrm{~g}, 9.77 \mathrm{mmol}$ ) and cyclopentanone $(0.87 \mathrm{~mL}, 9.77 \mathrm{mmol})$ were dissolved in DCE $(0.1 \mathrm{M})$. The reaction was cooled to $0{ }^{\circ} \mathrm{C}$, and $\mathrm{NaOAc}(801 \mathrm{mg}, 9.77 \mathrm{mmol})$ and $\mathrm{NaBH}(\mathrm{OAc})_{3}(4.14 \mathrm{~g}, 19.5 \mathrm{mmol})$ were added. The reaction was stirred at $\mathrm{rt}$ for $16 \mathrm{~h}$. Upon completion, sat. $\mathrm{NaHCO}_{3}$ was added and the aqueous phase was extracted with DCM $(\times 3)$. The combined organic phases were washed with water, dried over $\mathrm{MgSO}_{4}$, filtered, and concentrated in vacuo to afford compound 12a as a yellow oil (1.45 g, $7.83 \mathrm{mmol}, 80 \%)$. HRMS (ESI +ve): found $[\mathrm{M}]^{+} 186.1498$, $\left[\mathrm{C}_{10} \mathrm{H}_{20} \mathrm{NO}_{2}\right]^{+}$requires 186.1494; $[\alpha]_{\mathrm{D}}^{21.8}:-12.0\left(c\right.$ 1.0, MeOH); $\delta_{\mathrm{H}}$ $\left(500 \mathrm{MHz}, \mathrm{CDCl}_{3}\right): 3.73(\mathrm{~s}, 3 \mathrm{H}), 3.22(\mathrm{t}, J=6.6 \mathrm{~Hz}, 1 \mathrm{H}), 2.97$ (quin, $J=6.7 \mathrm{~Hz}, 1 \mathrm{H}), 1.83-1.60(\mathrm{~m}, 6 \mathrm{H}), 1.55-1.47(\mathrm{~m}, 2 \mathrm{H})$, $1.35-1.27(\mathrm{~m}, 2 \mathrm{H}), 0.92(\mathrm{t}, J=7.6 \mathrm{~Hz}, 3 \mathrm{H})$.

(S)-Methyl 2-(Cyclopentylamino)butanoate (12b). 12b was synthesized in $88 \%$ yield (brown oil, $1.42 \mathrm{~g}, 7.68 \mathrm{mmol}$ ) according to the same procedure as $\mathbf{1 2 d}$, from $(S)$-methyl 2 -aminobutanoate $11 \mathrm{~b}(\mathrm{HCl}$ salt, $1.34 \mathrm{~g}, 8.72 \mathrm{mmol})$ and cyclopentanone $(0.78 \mathrm{~mL}$, $8.72 \mathrm{mmol}$ ). HRMS (ESI +ve): found $[\mathrm{M}]^{+} 186.1498,\left[\mathrm{C}_{10} \mathrm{H}_{20} \mathrm{NO}_{2}\right]^{+}$ requires 186.1494; $[\alpha]_{\mathrm{D}}^{21.9}:+11.8(c 1.0, \mathrm{MeOH}) ; \delta_{\mathrm{H}}(500 \mathrm{MHz}$, $\mathrm{CDCl}_{3}$ ): $3.71(\mathrm{~s}, 3 \mathrm{H}), 3.20(\mathrm{t}, J=6.6 \mathrm{~Hz}, 1 \mathrm{H}), 2.96$ (quin, $J=6.7 \mathrm{~Hz}$, $1 \mathrm{H}), 1.83-1.58(\mathrm{~m}, 6 \mathrm{H}), 1.55-1.47(\mathrm{~m}, 2 \mathrm{H}), 1.35-1.27(\mathrm{~m}, 2 \mathrm{H})$, $0.91(\mathrm{t}, J=7.6 \mathrm{~Hz}, 3 \mathrm{H})$.

Methyl Cyclopentylglycinate (12c). 12c was synthesized in 39\% yield (yellow oil, $535 \mathrm{mg}, 3.40 \mathrm{mmol}$ ) according to the same procedure as $12 \mathrm{~d}$, from glycine methyl ester $11 \mathrm{c}(\mathrm{HCl}$ salt, $1.10 \mathrm{~g}$, $8.77 \mathrm{mmol})$ and cyclopentanone $(0.62 \mathrm{~mL}, 7.01 \mathrm{mmol})$. HRMS (ESI $+v e)$ : found $[\mathrm{M}]^{+} 158.1176,\left[\mathrm{C}_{8} \mathrm{H}_{15} \mathrm{NO}_{2}\right]^{+}$requires 158.1176; $\delta_{\mathrm{H}}$ $\left(500 \mathrm{MHz}, \mathrm{CDCl}_{3}\right): 3.73(\mathrm{~s}, 3 \mathrm{H}), 3.42(\mathrm{~s}, 2 \mathrm{H}), 3.07$ (quin, $J=6.5$ $\mathrm{Hz}, 1 \mathrm{H}), 1.85-1.77(\mathrm{~m}, 2 \mathrm{H}), 1.75-1.66(\mathrm{~m}, 2 \mathrm{H}), 1.60-1.50(\mathrm{~m}$, $2 \mathrm{H}), 1.40-1.32(\mathrm{~m}, 2 \mathrm{H})$.

(R)-Methyl 2-((3-Bromobenzyl)amino)butanoate (12d). 12d was synthesized in $92 \%$ yield (yellow oil, $1.37 \mathrm{~g}, 4.79 \mathrm{mmol}$ ) according to the same procedure as $12 \mathrm{a}$, from $(R)$-methyl 2-aminobutanoate 11a ( $\mathrm{HCl} \mathrm{salt,} 800 \mathrm{mg}, 5.21 \mathrm{mmol}$ ) and 3-bromobenzaldehyde $(0.61 \mathrm{~mL}$, $5.21 \mathrm{mmol})$. HRMS (ESI +ve): found $[\mathrm{M}]^{+}$286.0431, $\left[\mathrm{C}_{12} \mathrm{H}_{17} \mathrm{BrNO}_{2}\right]^{+}$requires 286.0437; $[\alpha]_{\mathrm{D}}^{21.9}:+22.9(c$ 1.0, MeOH); $\delta_{\mathrm{H}}\left(500 \mathrm{MHz}, \mathrm{CDCl}_{3}\right): 7.52(\mathrm{t}, J=1.6 \mathrm{~Hz}, 1 \mathrm{H}), 7.38(\mathrm{dt}, J=7.9,1.6$ $\mathrm{Hz}, 1 \mathrm{H}), 7.28-7.25(\mathrm{~m}, 1 \mathrm{H}), 7.20-7.17(\mathrm{~m}, 1 \mathrm{H}), 3.80$ (d, $J=13.2$ $\mathrm{Hz}, 1 \mathrm{H}), 3.74(\mathrm{~s}, 3 \mathrm{H}), 3.60(\mathrm{~d}, J=13.2 \mathrm{~Hz}, 1 \mathrm{H}), 3.20(\mathrm{t}, J=6.6 \mathrm{~Hz}$, $1 \mathrm{H}), 1.76-1.62(\mathrm{~m}, 2 \mathrm{H}), 0.96(\mathrm{t}, J=7.6 \mathrm{~Hz}, 3 \mathrm{H})$.

(R)-Methyl 2-(((3-Methylthiophen-2-yl)methyl)amino)butanoate (12e). 12e was synthesized in $74 \%$ yield (yellow oil, $720 \mathrm{mg}, 3.17$ $\mathrm{mmol}$ ) according to the same procedure as $\mathbf{1 2 d}$, from $(R)$-methyl 2aminobutanote 11a ( $\mathrm{HCl}$ salt, $500 \mathrm{mg}, 4.27 \mathrm{mmol}$ ) and 3methylthiophene-2-carbaldehyde $(0.46 \mathrm{~mL}, 4.27 \mathrm{mmol})$. HRMS $(\mathrm{ESI}+\mathrm{ve})$ : found $[\mathrm{M}]^{+}$228.1061, $\left[\mathrm{C}_{11} \mathrm{H}_{18} \mathrm{NO}_{2} \mathrm{~S}\right]^{+}$requires 228.1053; $[\alpha]_{\mathrm{D}}^{22.6}:+23.6($ c 1.0, $\mathrm{MeOH}) ; \delta_{\mathrm{H}}\left(500 \mathrm{MHz}, \mathrm{CDCl}_{3}\right)$ : $7.10(\mathrm{~d}, J=5.0 \mathrm{~Hz}, 1 \mathrm{H}), 6.78(\mathrm{~d}, J=5.4 \mathrm{~Hz}, 1 \mathrm{H}), 3.93(\mathrm{~d}, J=13.9$ $\mathrm{Hz}, 1 \mathrm{H}), 3.76-3.73(\mathrm{~m}, 4 \mathrm{H}), 3.27(\mathrm{t}, J=6.6 \mathrm{~Hz}, 1 \mathrm{H}), 2.17(\mathrm{~s}, 3 \mathrm{H})$, $1.74-1.62(\mathrm{~m}, 2 \mathrm{H}), 0.95(\mathrm{t}, J=6.9 \mathrm{~Hz}, 3 \mathrm{H})$.

(R)-Methyl 2-(((4-Methylthiophen-2-yl)methyl)amino)butanoate (12f). 12f was synthesized in 95\% yield (yellow oil, $1.70 \mathrm{~g}, 7.48$ $\mathrm{mmol}$ ) according to the same procedure as $12 \mathrm{~d}$, from $(R)$-methyl 2aminobutanote 11a ( $\mathrm{HCl}$ salt, $1.20 \mathrm{mg}, 7.81 \mathrm{mmol}$ ) and 4methylthiophene-2-carbaldehyde $(0.83 \mathrm{~mL}, 6.72 \mathrm{mmol})$. HRMS (ESI +ve): found $[\mathrm{M}]^{+}$228.1062, $\left[\mathrm{C}_{11} \mathrm{H}_{18} \mathrm{NO}_{2} \mathrm{~S}\right]^{+}$requires 228.1053; $[\alpha]_{\mathrm{D}}^{22.5}:+28.4\left(\right.$ c 1.0, MeOH); $\delta_{\mathrm{H}}\left(500 \mathrm{MHz}, \mathrm{CDCl}_{3}\right)$ : $6.78(\mathrm{t}, J=1.2 \mathrm{~Hz}, 1 \mathrm{H}), 6.73(\mathrm{~s}, 1 \mathrm{H}), 3.98(\mathrm{dd}, J=14.0,0.8 \mathrm{~Hz}, 1 \mathrm{H})$, $3.78(\mathrm{dd}, J=14.0,0.8 \mathrm{~Hz}, 1 \mathrm{H}), 3.74(\mathrm{~s}, 3 \mathrm{H}), 3.29(\mathrm{t}, J=6.5 \mathrm{~Hz}, 1 \mathrm{H})$, $2.22(\mathrm{~d}, J=1.2 \mathrm{~Hz}, 3 \mathrm{H}), 1.74-1.62(\mathrm{~m}, 2 \mathrm{H}), 0.95(\mathrm{t}, J=7.6 \mathrm{~Hz}, 3 \mathrm{H})$.

(R)-Methyl 2-(((5-Methylthiophen-2-yl)methyl)amino)butanoate (12g). 12g was synthesized in $77 \%$ yield (yellow oil, $892 \mathrm{mg}, 3.92$ $\mathrm{mmol}$ ) according to the same procedure as $12 \mathrm{~d}$, from $(R)$-methyl 2aminobutanote 11a ( $\mathrm{HCl}$ salt, $600 \mathrm{mg}, 5.12 \mathrm{mmol}$ ) and 5methylthiophene-2-carbaldehyde $(0.43 \mathrm{~mL}, 4.10 \mathrm{mmol})$. HRMS (ESI +ve): found $[\mathrm{M}]^{+}$228.1049, $\left[\mathrm{C}_{11} \mathrm{H}_{18} \mathrm{NO}_{2} \mathrm{~S}\right]^{+}$requires 228.1053; $[\alpha]_{\mathrm{D}}^{22.2}:+23.6(c 1.0, \mathrm{MeOH}) ; \delta_{\mathrm{H}}\left(500 \mathrm{MHz}, \mathrm{CDCl}_{3}\right)$ : $6.68(\mathrm{~d}, J=3.2 \mathrm{~Hz}, 1 \mathrm{H}), 6.58-6.55(\mathrm{~m}, 1 \mathrm{H}), 3.95(\mathrm{~d}, J=13.9 \mathrm{~Hz}$, $1 \mathrm{H}), 3.75(\mathrm{~d}, J=13.9 \mathrm{~Hz}, 1 \mathrm{H}), 3.73(\mathrm{~s}, 3 \mathrm{H}), 3.28(\mathrm{t}, J=6.6 \mathrm{~Hz}, 1 \mathrm{H})$, $2.45(\mathrm{~s}, 3 \mathrm{H}), 1.89(\mathrm{~s}, 1 \mathrm{H}), 1.74-1.61(\mathrm{~m}, 2 \mathrm{H}), 0.94(\mathrm{t}, J=6.9 \mathrm{~Hz}$, $3 \mathrm{H})$.

(R)-Methyl 2-((2-Chloro-5-nitropyrimidin-4-yl)(cyclopentyl)amino)butanoate (13a). 12a (700 mg, $3.78 \mathrm{mmol})$ and $\mathrm{NaHCO}_{3}$ $(635 \mathrm{mg}, 7.6 \mathrm{mmol})$ were dissolved in cyclohexane $(0.1 \mathrm{M})$ and stirred for $30 \mathrm{~min}$. 2,4-Dichloro-5-nitropyrimidine $(806 \mathrm{mg}, 4.16$ mmol) was added, and the reaction was stirred at $60{ }^{\circ} \mathrm{C}$ for $16 \mathrm{~h}$. Upon completion, the reaction mixture was filtered, washed with $\mathrm{CH}_{2} \mathrm{Cl}_{2}$, and concentrated in vacuo. The residue was purified by Biotage column chromatography (cHex/EtOAc, 0-20\%) to afford the title compound 13a as a yellow solid (1.03 g, $2.99 \mathrm{mmol}, 79 \%)$. HRMS (ESI +ve): found $[\mathrm{M}]^{+} 343.1165,\left[\mathrm{C}_{14} \mathrm{H}_{20} \mathrm{ClN}_{4} \mathrm{O}_{4}\right]^{+}$requires 343.1173; $[\alpha]_{\mathrm{D}}^{21.8}:+228.5($ c 1.0, $\mathrm{MeOH}) ; \delta_{\mathrm{H}}\left(500 \mathrm{MHz}, \mathrm{CDCl}_{3}\right):$ $8.67(\mathrm{~s}, 1 \mathrm{H}), 3.78-3.72(\mathrm{~m}, 1 \mathrm{H}), 3.76(\mathrm{~s}, 3 \mathrm{H}), 3.60-3.52(\mathrm{~m}, 1 \mathrm{H})$, 2.47-2.36 (m, 1H), 2.26-2.17 (m, 1H), 2.09-1.98 (m, 1H), 1.98$1.91(\mathrm{~m}, 1 \mathrm{H}), 1.84-1.56(\mathrm{~m}, 6 \mathrm{H}), 1.05(\mathrm{t}, J=7.6 \mathrm{~Hz}, 3 \mathrm{H})$.

(S)-Methyl 2-((2-Chloro-5-nitropyrimidin-4-yl)(cyclopentyl)amino)butanoate (13b). 13b was synthesized in 32\% yield (yellow solid, $830 \mathrm{mg}, 2.42 \mathrm{mmol}$ ) according to the same procedure as $13 \mathrm{~d}$, from $12 \mathrm{~b}(1.40 \mathrm{~g}, 7.56 \mathrm{mmol})$ and 2,4-dichloro-5-nitropyrimidine (1.61 g, $8.31 \mathrm{mmol}$ ). HRMS (ESI +ve): found $[\mathrm{M}]^{+}$343.1171, $\left[\mathrm{C}_{14} \mathrm{H}_{20} \mathrm{ClN}_{4} \mathrm{O}_{4}\right]^{+}$requires 343.1173; $[\alpha]_{\mathrm{D}}^{22.0}:-229.9(c \mathrm{cl} .0, \mathrm{MeOH})$; $\delta_{\mathrm{H}}\left(\mathrm{CDCl}_{3}, 500 \mathrm{MHz}\right): 8.67(\mathrm{~s}, 1 \mathrm{H}), 3.78-3.72(\mathrm{~m}, 1 \mathrm{H}), 3.76(\mathrm{~s}$, $3 \mathrm{H}), 3.60-3.51(\mathrm{~m}, 1 \mathrm{H}), 2.46-2.36(\mathrm{~m}, 1 \mathrm{H}), 2.25-2.17(\mathrm{~m}, 1 \mathrm{H})$, $2.09-2.01(\mathrm{~m}, 1 \mathrm{H}), 1.99-1.90(\mathrm{~m}, 1 \mathrm{H}), 1.84-1.47(\mathrm{~m}, 6 \mathrm{H}), 1.05(\mathrm{t}$, $J=7.6 \mathrm{~Hz}, 3 \mathrm{H})$.

Methyl N-(2-Chloro-5-nitropyrimidin-4-yl)-N-cyclopentylglycinate $(13 \mathrm{c}) .13 \mathrm{c}$ was synthesized in $78 \%$ yield (yellow solid, 416 $\mathrm{mg}, 1.32 \mathrm{mmol}$ ) according to the same procedure as $13 \mathrm{~d}$, from $12 \mathrm{c}$ $(265 \mathrm{mg}, 1.69 \mathrm{mmol})$ and 2,4-dichloro-5-nitropyrimidine $(360 \mathrm{mg}$, $1.85 \mathrm{mmol}$ ). HRMS (ESI +ve): found $[\mathrm{M}]^{+} 315.0843$, $\left[\mathrm{C}_{12} \mathrm{H}_{15} \mathrm{ClN}_{4} \mathrm{O}_{4}\right]^{+}$requires $315.0860 ; \delta_{\mathrm{H}}\left(\mathrm{CDCl}_{3}, 500 \mathrm{MHz}\right): 8.65$ (s, $1 \mathrm{H}), 4.17(\mathrm{~s}, 2 \mathrm{H}), 3.98-3.88(\mathrm{~m}, 1 \mathrm{H}), 3.79(\mathrm{~s}, 3 \mathrm{H}), 2.16-2.07$ (m, 2H), 1.78-1.70 (m, 2H), 1.64-1.53 (m, 4H).

(R)-Methyl 2-((3-Bromobenzyl)(2-chloro-5-nitropyrimidin-4-yl)amino)butanoate (13d). 13d was synthesized in $90 \%$ yield (yellow oil, $1.81 \mathrm{~g}, 4.08 \mathrm{mmol}$ ) according to the same procedure as 13a, from $12 \mathrm{~d}(1.30 \mathrm{~g}, 4.54 \mathrm{mmol})$ and 2,4-dichloro-5-nitropyrimidine $(970 \mathrm{mg}$, $5.00 \mathrm{mmol}$ ). HRMS (ESI +ve): found $[\mathrm{M}]^{+} 443.0118$, $\left[\mathrm{C}_{16} \mathrm{H}_{17} \mathrm{BrClN}_{4} \mathrm{O}_{4}\right]^{+}$requires 443.0122; $[\alpha]_{\mathrm{D}}^{22.0}:+12.0$ (c 1.0, $\mathrm{MeOH}) ; \delta_{\mathrm{H}}\left(500 \mathrm{MHz}, \mathrm{CDCl}_{3}\right): 8.64(\mathrm{~s}, 1 \mathrm{H}), 7.45(\mathrm{~s}, 1 \mathrm{H}), 7.41$ $(\mathrm{d}, J=7.8 \mathrm{~Hz}, 1 \mathrm{H}), 7.23(\mathrm{~d}, J=7.8 \mathrm{~Hz}, 1 \mathrm{H}), 7.17-7.13(\mathrm{~m}, 1 \mathrm{H})$, $4.75(\mathrm{~d}, J=15.8 \mathrm{~Hz}, 1 \mathrm{H}), 4.73-4.68(\mathrm{~m}, 1 \mathrm{H}), 4.59(\mathrm{~d}, J=15.8 \mathrm{~Hz}$, $1 \mathrm{H}), 3.82(\mathrm{~s}, 3 \mathrm{H}), 2.32-2.23(\mathrm{~m}, 1 \mathrm{H}), 2.10-2.00(\mathrm{~m}, 1 \mathrm{H}), 1.07(\mathrm{t}, J$ $=7.4 \mathrm{~Hz}, 3 \mathrm{H})$.

(R)-Methyl 2-((2-Chloro-5-nitropyrimidin-4-yl))((3-methylthiophen-2-yl)methyl)amino)butanoate (13e). 13e was synthesized in 90\% yield (yellow solid, $1.18 \mathrm{~g}, 3.07 \mathrm{mmol}$ ) according to the same procedure as $13 \mathrm{~d}$, from $12 \mathrm{e}(770 \mathrm{mg}, 3.39 \mathrm{mmol})$ and 2,4-dichloro-5nitropyrimidine $(723 \mathrm{mg}, 3.72 \mathrm{mmol})$. HRMS (ESI +ve): found $[\mathrm{M}]^{+}$ 385.0732, $\left[\mathrm{C}_{15} \mathrm{H}_{17} \mathrm{ClN}_{4} \mathrm{O}_{4} \mathrm{~S}\right]^{+}$requires 385.0732; $[\alpha]_{\mathrm{D}}^{22.1}:+4.85(c$ 1.0, $\mathrm{MeOH}) ; \delta_{\mathrm{H}}\left(500 \mathrm{MHz}, \mathrm{CDCl}_{3}\right): 8.65(\mathrm{~s}, 1 \mathrm{H}), 7.15(\mathrm{~d}, J=5.2 \mathrm{~Hz}$, $1 \mathrm{H}), 6.70(\mathrm{~d}, J=5.2 \mathrm{~Hz}, \mathrm{H} 2), 4.92(\mathrm{dd}, J=5.4,4.1 \mathrm{~Hz}, 1 \mathrm{H}), 4.75(\mathrm{~s}$, $2 \mathrm{H}), 3.80(\mathrm{~s}, 3 \mathrm{H}), 2.30-2.20(\mathrm{~m}, 1 \mathrm{H}), 2.16(\mathrm{~s}, 3 \mathrm{H}), 2.07-2.00(\mathrm{~m}$, $1 \mathrm{H}), 1.09(\mathrm{t}, J=7.4 \mathrm{~Hz}, 3 \mathrm{H})$.

(R)-Methyl 2-((2-Chloro-5-nitropyrimidin-4-yl)((4-methylthiophen-2-yl)methyl)amino)butanoate (13f). 13f was synthesized in $81 \%$ yield (yellow solid, $2.32 \mathrm{~g}, 6.03 \mathrm{mmol}$ ) according to the same procedure as $13 \mathrm{~d}$, from $12 \mathrm{f}(1.70 \mathrm{~g}, 7.48 \mathrm{mmol})$ and 2,4-dichloro-5nitropyrimidine $(1.60 \mathrm{~g}, 8.23 \mathrm{mmol})$. HRMS (ESI +ve): found $[\mathrm{M}]^{+}$ 385.0738, $\left[\mathrm{C}_{15} \mathrm{H}_{17} \mathrm{ClN}_{4} \mathrm{O}_{4} \mathrm{~S}\right]^{+}$requires 385.0732; $[\alpha]_{\mathrm{D}}^{22.5}:+5.54(c 1.0$, $\mathrm{MeOH}) ; \delta_{\mathrm{H}}\left(500 \mathrm{MHz}, \mathrm{CDCl}_{3}\right): 8.70(\mathrm{~s}, 1 \mathrm{H}), 6.82-6.81(\mathrm{~m}, 1 \mathrm{H})$, $6.71(\mathrm{~s}, 1 \mathrm{H}), 4.95-4.80(\mathrm{~m}, 3 \mathrm{H}), 3.82(\mathrm{~s}, 3 \mathrm{H}), 2.32-2.22(\mathrm{~m}, 1 \mathrm{H})$, $2.18(\mathrm{~s}, 3 \mathrm{H}), 2.09-2.00(\mathrm{~m}, 1 \mathrm{H}), 1.07(\mathrm{t}, J=7.4 \mathrm{~Hz}, 3 \mathrm{H})$.

(R)-Methyl 2-((2-Chloro-5-nitropyrimidin-4-yl)((5-methylthiophen-2-yl)methyl)amino)butanoate (13g). 13g was synthesized in $86 \%$ yield (yellow gum, $1.30 \mathrm{~g}, 3.38 \mathrm{mmol}$ ) according to the same procedure as $13 \mathrm{~d}$, from $12 \mathrm{~g}(892 \mathrm{mg}, 3.92 \mathrm{mmol})$ and 2,4-dichloro-5- 
nitropyrimidine $(837 \mathrm{mg}, 4.31 \mathrm{mmol})$. HRMS (ESI +ve): found $[\mathrm{M}]^{+}$ 385.0732, $\left[\mathrm{C}_{15} \mathrm{H}_{17} \mathrm{ClN}_{4} \mathrm{O}_{4} \mathrm{~S}\right]^{+}$requires 385.0732; $[\alpha]_{\mathrm{D}}^{22.4}:-2.78(c$ $1.0, \mathrm{MeOH}) ; \delta_{\mathrm{H}}\left(500 \mathrm{MHz}, \mathrm{CDCl}_{3}\right): 8.68(\mathrm{~s}, 1 \mathrm{H}), 6.67(\mathrm{~d}, J=2.5$ $\mathrm{Hz}, 1 \mathrm{H}), 6.52(\mathrm{~d}, J=2.5 \mathrm{~Hz}, \mathrm{H} 2), 4.98-4.93(\mathrm{~m}, 1 \mathrm{H}), 4.84(\mathrm{~d}, J=$ $15.9 \mathrm{~Hz}, 1 \mathrm{H}), 4.81(\mathrm{~d}, J=15.9 \mathrm{~Hz}, 1 \mathrm{H}), 3.81(\mathrm{~s}, 3 \mathrm{H}), 2.38(\mathrm{~s}, 3 \mathrm{H})$, $2.31-2.21(\mathrm{~m}, 1 \mathrm{H}), 2.08-2.00(\mathrm{~m}, 1 \mathrm{H}), 1.06(\mathrm{t}, J=7.4 \mathrm{~Hz}, 3 \mathrm{H})$.

(R)-2-Chloro-8-cyclopentyl-7-ethyl-7,8-dihydropteridin-6(5H)one (14a). A mixture of $13 \mathrm{a}(1.00 \mathrm{~g}, 2.92 \mathrm{mmol})$ in $\mathrm{AcOH}(0.4 \mathrm{M})$ was heated to $100{ }^{\circ} \mathrm{C}$. Iron powder $(196 \mathrm{mg}, 3.5 \mathrm{mmol})$ was added batchwise, and the reaction was stirred for $6 \mathrm{~h}$. Upon completion, the mixture was filtered through celite, washed with $\mathrm{MeOH}$, and concentrated in vacuo. The residue was purified by Biotage column chromatography (cHex/EtOAc, $0-40 \%$ ) to afford the title compound 14a as a yellow solid ( $345 \mathrm{mg}, 1.23 \mathrm{mmol}, 25 \%)$. HRMS (ESI +ve): found $[\mathrm{M}]^{+}$281.1163, $\left[\mathrm{C}_{13} \mathrm{H}_{18} \mathrm{ClN}_{4} \mathrm{O}\right]^{+}$requires 281.1169; $[\alpha]_{\mathrm{D}}^{22.1}$ : -96.2 (c 1.0, MeOH); $\delta_{\mathrm{H}}\left(500 \mathrm{MHz}, \mathrm{CDCl}_{3}\right): 9.39$ (s, 1H), 7.68 (s, $1 \mathrm{H}), 4.37-4.29(\mathrm{~m}, 1 \mathrm{H}), 4.21(\mathrm{dd}, J=7.4,3.6 \mathrm{~Hz}, 1 \mathrm{H}), 2.11-2.05$ (m, 1H), 2.00-1.74 (m, 7H), 1.70-1.61 (m, 2H), $0.96(\mathrm{t}, J=7.6 \mathrm{~Hz}$, $3 \mathrm{H})$.

(S)-2-Chloro-8-cyclopentyl-7-ethyl-7,8-dihydropteridin-6(5H)one (14b). 14b was synthesized in $28 \%$ yield (yellow solid, $186 \mathrm{mg}$, $0.66 \mathrm{mmol})$ according to the same procedure as $14 \mathrm{~d}$, from $13 \mathrm{~b}(815$ $\mathrm{mg}, 2.38 \mathrm{mmol}$ ). HRMS (ESI +ve): found $[\mathrm{M}]^{+}$281.1163, $\left[\mathrm{C}_{13} \mathrm{H}_{18} \mathrm{ClN}_{4} \mathrm{O}\right]^{+}$requires 281.1169; $[\alpha]_{\mathrm{D}}^{22.1}:+95.3(c$ 1.0, MeOH); $\delta_{\mathrm{H}}\left(500 \mathrm{MHz}, \mathrm{CDCl}_{3}\right): 9.67(\mathrm{~s}, 1 \mathrm{H}), 7.70(\mathrm{~s}, 1 \mathrm{H}), 4.32$ (quin, $J=8.4$ $\mathrm{Hz}, 1 \mathrm{H}), 4.21(\mathrm{dd}, J=7.3,3.5 \mathrm{~Hz}, 1 \mathrm{H}), 2.12-2.04(\mathrm{~m}, 1 \mathrm{H}), 2.00-$ $1.73(\mathrm{~m}, 7 \mathrm{H}), 1.70-1.60(\mathrm{~m}, 2 \mathrm{H}), 0.94(\mathrm{t}, J=7.6 \mathrm{~Hz}, 3 \mathrm{H})$.

2-Chloro-8-cyclopentyl-7,8-dihydropteridin-6(5H)-one (14c). 14c was synthesized in $31 \%$ yield (orange solid, $101 \mathrm{mg}, 0.40 \mathrm{mmol}$ ) according to the same procedure as $14 \mathrm{~d}$, from $13 \mathrm{c}(410 \mathrm{mg}, 1.30$ mmol). HRMS (ESI +ve): found $[\mathrm{M}]^{+} 281.1163,\left[\mathrm{C}_{13} \mathrm{H}_{18} \mathrm{ClN}_{4} \mathrm{O}\right]^{+}$ requires 281.1169; $[\alpha]_{\mathrm{D}}^{22.1}:+95.3(c 1.0, \mathrm{MeOH}) ; \delta_{\mathrm{H}}(500 \mathrm{MHz}$, $\left.\mathrm{CDCl}_{3}\right): 7.98(\mathrm{~s}, 1 \mathrm{H}), 7.60(\mathrm{~s}, 1 \mathrm{H}), 6.15($ quin, $J=8.4 \mathrm{~Hz}, 1 \mathrm{H}), 4.11$ $(\mathrm{s}, 2 \mathrm{H}), 1.98-1.89(\mathrm{~m}, 2 \mathrm{H}), 1.80-1.57(\mathrm{~m}, 6 \mathrm{H})$.

(R)-2-Chloro-8-(3-bromobenzyl)-7-ethyl-7,8-dihydropteridin$6(5 H)$-one $(14 d)$. $14 \mathrm{~d}$ was synthesized in $42 \%$ yield (orange solid, 387 $\mathrm{mg}, 1.01 \mathrm{mmol}$ ) according to the same procedure as $14 \mathrm{a}$, from $13 \mathrm{~d}$ $(1.80 \mathrm{~g}, 4.06 \mathrm{mmol})$. HRMS (ESI +ve): found $[\mathrm{M}]^{+} 383.0078$, $\left[\mathrm{C}_{15} \mathrm{H}_{15} \mathrm{BrClN}_{4} \mathrm{O}\right]^{+}$requires 383.0091; $[\alpha]_{\mathrm{D}}^{22.0}:-18.0(c \mathrm{c} .0, \mathrm{MeOH})$; $\delta_{\mathrm{H}}\left(500 \mathrm{MHz}, \mathrm{CDCl}_{3}\right): 9.33(\mathrm{~s}, 1 \mathrm{H}), 7.71(\mathrm{~s}, 1 \mathrm{H}), 7.48-7.45(\mathrm{~m}$, $1 \mathrm{H}), 7.45(\mathrm{~s}, 1 \mathrm{H}), 7.26-7.23(\mathrm{~m}, 2 \mathrm{H}), 5.62(\mathrm{~d}, J=15.1,1 \mathrm{H}), 4.16-$ $4.12(\mathrm{~m}, 1 \mathrm{H}), 4.08(\mathrm{~d}, J=15.1,1 \mathrm{H}), 2.05-1.97(\mathrm{~m}, 1 \mathrm{H}), 1.96-1.86$ $(\mathrm{m}, 1 \mathrm{H}), 0.91(\mathrm{t}, J=7.4 \mathrm{~Hz}, 3 \mathrm{H})$.

(R)-2-Chloro-7-ethyl-8-((3-methylthiophen-2-yl)methyl)-7,8-dihydropteridin-6(5H)-one (14e). 14e was synthesized in $47 \%$ yield (orange solid, $380 \mathrm{mg}, 1.17 \mathrm{mmol}$ ) according to the same procedure as 14d, from 13e (960 mg, $2.49 \mathrm{mmol}$ ). HRMS (ESI +ve): found $[\mathrm{M}]^{+}$323.0724, $\left[\mathrm{C}_{14} \mathrm{H}_{15} \mathrm{ClN}_{4} \mathrm{OS}\right]^{+}$requires 323.0728; $[\alpha]_{\mathrm{D}}^{22.2}:-11.1$ $(c \mathrm{l}, 0, \mathrm{MeOH}) ; \delta_{\mathrm{H}}\left(500 \mathrm{MHz}, \mathrm{CDCl}_{3}\right): 8.70(\mathrm{~s}, 1 \mathrm{H}), 7.65(\mathrm{~s}, 1 \mathrm{H})$, $6.86(\mathrm{~d}, J=3.3 \mathrm{~Hz}, 1 \mathrm{H}), 6.63-6.61(\mathrm{~m}, 1 \mathrm{H}), 5.55(\mathrm{~d}, J=15.5,1 \mathrm{H})$, $4.33-4.29(\mathrm{~m}, 2 \mathrm{H}), 2.46(\mathrm{~s}, 3 \mathrm{H}), 2.07-1.88(\mathrm{~m}, 2 \mathrm{H}), 0.90(\mathrm{t}, J=7.4$ $\mathrm{Hz}, 3 \mathrm{H})$.

(R)-2-Chloro-7-ethyl-8-((4-methylthiophen-2-yl)methyl)-7,8-dihydropteridin-6(5H)-one (14f). 14f was synthesized in $42 \%$ yield (orange solid, $300 \mathrm{mg}, 0.93 \mathrm{mmol}$ ) according to the same procedure as 14d, from $13 \mathrm{f}(860 \mathrm{mg}, 2.23 \mathrm{mmol})$. HRMS (ESI +ve): found $[\mathrm{M}]^{+}$323.0728, $\left[\mathrm{C}_{14} \mathrm{H}_{15} \mathrm{ClN}_{4} \mathrm{OS}\right]^{+}$requires 323.0728; $[\alpha]_{\mathrm{D}}^{22.8}:-18.0$ (c 1.0, $\mathrm{MeOH}) ; \delta_{\mathrm{H}}\left(500 \mathrm{MHz}, \mathrm{CDCl}_{3}\right): 7.73(\mathrm{~s}, 1 \mathrm{H}), 6.86(\mathrm{~s}, 1 \mathrm{H})$, $6.83(\mathrm{~d}, J=1.0 \mathrm{~Hz}, 1 \mathrm{H}), 5.58(\mathrm{~d}, J=15.5 \mathrm{~Hz}, 1 \mathrm{H}), 4.32-4.28(\mathrm{~m}$, $2 \mathrm{H}), 2.23(\mathrm{~s}, 3 \mathrm{H}), 2.07-1.99(\mathrm{~m}, 1 \mathrm{H}), 1.97-1.86(\mathrm{~m}, 1 \mathrm{H}), 0.89(\mathrm{t}, J$ $=7.4 \mathrm{~Hz}, 3 \mathrm{H})$.

(R)-2-Chloro-7-ethyl-8-((5-methylthiophen-2-yl)methyl)-7,8-dihydropteridin-6(5H)-one $(\mathbf{1 4 g}) .14 \mathrm{~g}$ was synthesized in $18 \%$ yield (orange solid, $200 \mathrm{mg}, 0.62 \mathrm{mmol}$ ) according to the same procedure as $14 \mathrm{~d}$, from $13 \mathrm{~g}(1.30 \mathrm{~g}, 3.38 \mathrm{mmol})$. HRMS (ESI +ve): found $[\mathrm{M}]^{+}$ 323.0727, $\left[\mathrm{C}_{14} \mathrm{H}_{15} \mathrm{ClN}_{4} \mathrm{OS}\right]^{+}$requires 323.0728; $[\alpha]_{\mathrm{D}}^{22.5}:+18.7(c 1.0$, $\mathrm{MeOH}) ; \delta_{\mathrm{H}}\left(500 \mathrm{MHz}, \mathrm{CDCl}_{3}\right): 9.20(\mathrm{~s}, 1 \mathrm{H}), 7.69(\mathrm{~s}, 1 \mathrm{H}), 7.18(\mathrm{~d}, J$ $=5.2 \mathrm{~Hz}, 1 \mathrm{H}), 6.83(\mathrm{~d}, J=5.2 \mathrm{~Hz}, 1 \mathrm{H}), 5.64(\mathrm{~d}, J=15.5 \mathrm{~Hz}, 1 \mathrm{H})$, $4.29(\mathrm{~d}, J=15.5 \mathrm{~Hz}, 1 \mathrm{H}), 4.24(\mathrm{dd}, J=6.3,3.5 \mathrm{~Hz}, 1 \mathrm{H}), 2.26(\mathrm{~s}, 3 \mathrm{H})$, 2.05-1.99 (m, 1H), $1.98-1.87(\mathrm{~m}, 1 \mathrm{H}), 0.92(\mathrm{t}, J=7.6 \mathrm{~Hz}, 3 \mathrm{H})$.
(R)-2-Chloro-8-cyclopentyl-7-ethyl-5-methyl-7,8-dihydropteridin-6(5H)-one (15a). 14a $(200 \mathrm{mg}, 0.72 \mathrm{mmol})$ was dissolved in DMF $(0.1 \mathrm{M})$, methyl iodide $(58 \mu \mathrm{L}, 0.93 \mathrm{mmol})$ was added, and the mixture was cooled to $-10^{\circ} \mathrm{C}$. $\mathrm{NaH}(22 \mathrm{mg}, 0.93 \mathrm{mmol})$ was added, and the reaction was stirred for $16 \mathrm{~h}$. Upon completion, ice was added and the aqueous phase was extracted with EtOAc $(\times 3)$. The combined organic phases were washed with water, dried over $\mathrm{MgSO}_{4}$, filtered, and concentrated in vacuo. The residue was purified by Biotage column chromatography (cHex/EtOAc, 0-20\%) to afford the title compound 15a as a white solid (200 mg, $0.68 \mathrm{mmol}, 71 \%)$. HRMS (ESI +ve): found $[\mathrm{M}]^{+} 295.1321,\left[\mathrm{C}_{14} \mathrm{H}_{20} \mathrm{ClN}_{4} \mathrm{O}\right]^{+}$requires 295.1326; $[\alpha]_{\mathrm{D}}^{21.4}:-88.3(c 1.0, \mathrm{MeOH}) ; \delta_{\mathrm{H}}\left(500 \mathrm{MHz}, \mathrm{CDCl}_{3}\right): 7.62$ (s, $1 \mathrm{H}), 4.41-4.29(\mathrm{~m}, 1 \mathrm{H}), 4.25(\mathrm{dd}, J=7.6,3.5 \mathrm{~Hz}, 1 \mathrm{H}), 3.33(\mathrm{~s}$, $3 \mathrm{H}), 2.12-2.04(\mathrm{~m}, 1 \mathrm{H}), 2.02-1.58(\mathrm{~m}, 9 \mathrm{H}), 0.86(\mathrm{t}, J=7.4 \mathrm{~Hz}$, $3 \mathrm{H})$.

(S)-2-Chloro-8-cyclopentyl-7-ethyl-5-methyl-7,8-dihydropteridin-6(5H)-one (15b). 15b was synthesized in $95 \%$ yield (white solid, $180 \mathrm{mg}, 0.61 \mathrm{mmol}$ ) according to the same procedure as $15 \mathrm{~d}$, from $14 \mathrm{~b}(180 \mathrm{mg}, 0.64 \mathrm{mmol})$ and methyl iodide $(52 \mu \mathrm{L}, 0.83 \mathrm{mmol})$. HRMS (ESI +ve): found $[\mathrm{M}]^{+} 295.1321,\left[\mathrm{C}_{14} \mathrm{H}_{20} \mathrm{ClN}_{4} \mathrm{O}\right]^{+}$requires 295.1326; $[\alpha]_{\mathrm{D}}^{21.5}:+93.5(c 1.0, \mathrm{MeOH}) ; \delta_{\mathrm{H}}\left(500 \mathrm{MHz}, \mathrm{CDCl}_{3}\right): 7.65$ $(\mathrm{s}, 1 \mathrm{H}), 4.37-4.28(\mathrm{~m}, 1 \mathrm{H}), 4.23(\mathrm{dd}, J=7.6,3.8 \mathrm{~Hz}, 1 \mathrm{H}), 3.31(\mathrm{~s}$, $3 \mathrm{H}), 2.10-2.02(\mathrm{~m}, 1 \mathrm{H}), 2.00-1.58(\mathrm{~m}, 9 \mathrm{H}), 0.85(\mathrm{t}, J=7.6 \mathrm{~Hz}$, $3 \mathrm{H})$.

2-Chloro-8-cyclopentyl-5-methyl-7,8-dihydropteridin-6(5H)-one (15c). 15c was synthesized in 59\% yield (white solid, $53 \mathrm{mg}, 0.20$ $\mathrm{mmol}$ ) according to the same procedure as $15 \mathrm{~d}$, from $14 \mathrm{c}(85 \mathrm{mg}$, $0.37 \mathrm{mmol}$ ) and methyl iodide $(27 \mu \mathrm{L}, 0.43 \mathrm{mmol}$ ). HRMS (ESI +ve): found $[\mathrm{M}]^{+}$267.0995, $\left[\mathrm{C}_{12} \mathrm{H}_{15} \mathrm{ClN}_{4} \mathrm{O}\right]^{+}$requires 267.1007; $\delta_{\mathrm{H}}$ $\left(500 \mathrm{MHz}, \mathrm{CDCl}_{3}\right): 7.67(\mathrm{~s}, 1 \mathrm{H}), 5.14$ (quin, $\left.J=8.4 \mathrm{~Hz}, 1 \mathrm{H}\right), 4.13$ $(\mathrm{s}, 2 \mathrm{H}), 4.37-4.28(\mathrm{~m}, 1 \mathrm{H}), 3.33(\mathrm{~s}, 3 \mathrm{H}), 1.97-1.91(\mathrm{~m}, 2 \mathrm{H}), 1.81-$ $1.65(\mathrm{~m}, 4 \mathrm{H}), 1.64-1.56(\mathrm{~m}, 2 \mathrm{H})$.

(R)-8-(3-Bromobenzyl)-2-chloro-7-ethyl-5-methyl-7,8-dihydropteridin-6(5H)-one (15d). 15d was synthesized in $71 \%$ yield (yellow solid, $200 \mathrm{mg}, 0.51 \mathrm{mmol}$ ) according to the same procedure as $15 \mathrm{a}$, from $14 \mathrm{~d}(270 \mathrm{mg}, 0.71 \mathrm{mmol})$ and methyl iodide $(58 \mu \mathrm{L}, 0.92$ mmol). HRMS (ESI +ve): found $[\mathrm{M}]^{+} 395.0269,\left[\mathrm{C}_{16} \mathrm{H}_{17} \mathrm{BrClN}_{4} \mathrm{O}\right]^{+}$ requires 395.0274; $[\alpha]_{\mathrm{D}}^{22.1}:+15.2($ c $1.0, \mathrm{MeOH}) ; \delta_{\mathrm{H}}(500 \mathrm{MHz}$, $\left.\mathrm{CDCl}_{3}\right): 7.73(\mathrm{~s}, 1 \mathrm{H}), 7.48-7.44(\mathrm{~m}, 2 \mathrm{H}), 7.25-7.22(\mathrm{~m}, 2 \mathrm{H}), 5.62$ $(\mathrm{d}, J=15.1 \mathrm{~Hz}, 1 \mathrm{H}), 4.17(\mathrm{dd}, J=6.3,3.5 \mathrm{~Hz}, 1 \mathrm{H}), 4.09(\mathrm{~d}, J=15.1$ $\mathrm{Hz}, 1 \mathrm{H}), 3.35(\mathrm{~s}, 3 \mathrm{H}), 2.02-1.93(\mathrm{~m}, 1 \mathrm{H}), 1.90-1.80(\mathrm{~m}, 1 \mathrm{H}), 0.84$ $(\mathrm{t}, J=7.4 \mathrm{~Hz}, 3 \mathrm{H})$.

(R)-2-Chloro-7-ethyl-5-methyl-8-(3-methylthiophen-2-yl)-7,8-dihydropteridin-6(5H)-one (15e). 15e was synthesized in $48 \%$ yield (yellow solid, $186 \mathrm{mg}, 0.55 \mathrm{mmol}$ ) according to the same procedure as $15 \mathrm{~d}$, from $14 \mathrm{e}(370 \mathrm{mg}, 1.15 \mathrm{mmol})$ and methyl iodide $(72 \mu \mathrm{L}$, $1.15 \mathrm{mmol}$ ). HRMS (ESI +ve): found $[\mathrm{M}]^{+} 337.0901$, $\left[\mathrm{C}_{15} \mathrm{H}_{17} \mathrm{ClN}_{4} \mathrm{OS}\right]^{+}$requires 337.0884; $[\alpha]_{\mathrm{D}}^{23.3}:+6.9($ c 1.0, MeOH $)$; $\delta_{\mathrm{H}}\left(500 \mathrm{MHz}, \mathrm{CDCl}_{3}\right): 7.69(\mathrm{~s}, 1 \mathrm{H}), 7.17(\mathrm{~d}, J=5.4 \mathrm{~Hz}, 1 \mathrm{H}), 6.83$ $(\mathrm{d}, J=5.4 \mathrm{~Hz}, 1 \mathrm{H}), 5.61(\mathrm{~d}, J=15.3 \mathrm{~Hz}, 1 \mathrm{H}), 4.29(\mathrm{~d}, J=15.3 \mathrm{~Hz}$, $1 \mathrm{H}), 4.27(\mathrm{dd}, J=6.6,3.5 \mathrm{~Hz}, 1 \mathrm{H}), 3.32(\mathrm{~s}, 3 \mathrm{H}), 2.25(\mathrm{~s}, 3 \mathrm{H}), 2.03-$ $1.93(\mathrm{~m}, 1 \mathrm{H}), 1.91-1.81(\mathrm{~m}, 1 \mathrm{H}), 0.84(\mathrm{t}, J=7.6 \mathrm{~Hz}, 3 \mathrm{H})$.

(R)-2-Chloro-7-ethyl-5-methyl-8-(4-methylthiophen-2-yl)-7,8-dihydropteridin-6(5H)-one (15f). 15f was synthesized in $53 \%$ yield (yellow oil, $260 \mathrm{mg}, 0.77 \mathrm{mmol}$ ) according to the same procedure as 15d, from $14 \mathrm{f}(470 \mathrm{mg}, 1.46 \mathrm{mmol})$ and methyl iodide $(19 \mu \mathrm{L}, 1.90$ mmol). HRMS (ESI +ve): found $[\mathrm{M}]^{+} 337.0881,\left[\mathrm{C}_{15} \mathrm{H}_{17} \mathrm{ClN}_{4} \mathrm{OS}\right]^{+}$ requires 337.0884; $[\alpha]_{\mathrm{D}}^{23.3}:+4.9($ c 1.0, $\mathrm{MeOH}) ; \delta_{\mathrm{H}}(500 \mathrm{MHz}$, $\left.\mathrm{CDCl}_{3}\right): 7.69(\mathrm{~s}, 1 \mathrm{H}), 6.86(\mathrm{~s}, 1 \mathrm{H}), 6.82(\mathrm{~s}, 1 \mathrm{H}), 5.56(\mathrm{~d}, J=15.5 \mathrm{~Hz}$, $1 \mathrm{H}), 4.33-4.29(2 \mathrm{H}, \mathrm{m}), 3.31(\mathrm{~s}, 3 \mathrm{H}), 2.22(\mathrm{~s}, 3 \mathrm{H}), 2.03-1.95(\mathrm{~m}$, $1 \mathrm{H}), 1.91-1.84(\mathrm{~m}, 1 \mathrm{H}), 0.81(\mathrm{t}, J=7.4 \mathrm{~Hz}, 3 \mathrm{H})$.

(R)-2-Chloro-7-ethyl-5-methyl-8-(5-methylthiophen-2-yl)-7,8-dihydropteridin-6(5H)-one (15g). 15g was synthesized in 53\% yield (yellow solid, $110 \mathrm{mg}, 0.33 \mathrm{mmol}$ ) according to the same procedure as $15 \mathrm{~d}$, from $14 \mathrm{~g}(200 \mathrm{mg}, 0.62 \mathrm{mmol})$ and methyl iodide $(39 \mu \mathrm{L}$, $0.62 \mathrm{mmol}$ ). HRMS (ESI +ve): found $[\mathrm{M}]^{+}$337.0866, $\left[\mathrm{C}_{15} \mathrm{H}_{17} \mathrm{ClN}_{4} \mathrm{OS}\right]^{+}$requires 337.0884; $[\alpha]_{\mathrm{D}}^{23.5}:+1.7(c 1.0, \mathrm{MeOH})$; $\delta_{\mathrm{H}}\left(500 \mathrm{MHz}, \mathrm{CDCl}_{3}\right): 7.69(\mathrm{~s}, 1 \mathrm{H}), 6.85(\mathrm{~d}, J=3.5 \mathrm{~Hz}, 1 \mathrm{H}), 6.61-$ $6.59(\mathrm{~m}, 1 \mathrm{H}), 5.53(\mathrm{~d}, J=15.5 \mathrm{~Hz}, 1 \mathrm{H}), 4.33-4.29(2 \mathrm{H}, \mathrm{m}), 3.32(\mathrm{~s}$, 
$3 \mathrm{H}), 2.45(\mathrm{~s}, 3 \mathrm{H}), 2.04-1.95(\mathrm{~m}, 1 \mathrm{H}), 1.91-1.83(\mathrm{~m}, 1 \mathrm{H}), 0.82(\mathrm{t}, J$ $=7.4 \mathrm{~Hz}, 3 \mathrm{H})$.

(R)-8-Cyclopentyl-7-ethyl-2-((2-methoxy-4-(1-methylpiperidin-4yl)phenyl)amino)-5-methyl-7,8-dihydropteridin-6(5H)-one (16a). To $15 \mathrm{a}(25 \mathrm{mg}, 80 \mu \mathrm{mol})$ and $10 \mathrm{~b}(18 \mathrm{mg}, 80 \mu \mathrm{mol})$ in a solvent mixture of dioxane/EtOH/ $\mathrm{H}_{2} \mathrm{O}(1: 1: 1,0.1 \mathrm{M})$ was added conc. $\mathrm{HCl}$ $(24 \mu \mathrm{L}, 110 \mu \mathrm{mol})$. The reaction was stirred at $120^{\circ} \mathrm{C}$ for $48 \mathrm{~h}$. Upon completion, the reaction mixture was partitioned between EtOAc and $\mathrm{NaOH}(1 \mathrm{M})$ and the aqueous layer was further extracted with EtOAc $(\times 2)$. The organic phase was combined, dried over $\mathrm{MgSO}_{4}$, and concentrated in vacuo. The residue was purified by Biotage column chromatography (DCM/20\% amm. $\mathrm{MeOH}, 0-40 \%)$ and reverse phase column chromatography (water/ $\mathrm{MeOH}, 0-100 \%$ ) to afford 16a as a yellow solid ( $9.0 \mathrm{mg}, 19 \mu \mathrm{mol}, 22 \%)$. HRMS (ESI +ve): found $[\mathrm{M}]^{+}$479.3101, $\left[\mathrm{C}_{27} \mathrm{H}_{38} \mathrm{~N}_{6} \mathrm{O}_{2}\right]^{+}$requires 479.3129; $[\alpha]_{\mathrm{D}}^{21.8}$ : -9.1 (c 1.0, $\mathrm{MeOH}) ; \delta_{\mathrm{H}}\left(500 \mathrm{MHz}, \mathrm{CDCl}_{3}\right): 8.20(\mathrm{~d}, J=8.2 \mathrm{~Hz}$, $1 \mathrm{H}), 7.88(\mathrm{~s}, 1 \mathrm{H}), 7.61(\mathrm{~s}, 1 \mathrm{H}), 6.80(\mathrm{dd}, J=8.2,1.9 \mathrm{~Hz}, 1 \mathrm{H}), 6.75$ $(\mathrm{d}, J=1.9 \mathrm{~Hz}, 1 \mathrm{H}), 4.42($ quin, $J=8.0 \mathrm{~Hz}, 1 \mathrm{H}), 4.21(\mathrm{dd}, J=7.7 .3 .6$ $\mathrm{Hz}, 1 \mathrm{H}), 3.90(\mathrm{~s}, 3 \mathrm{H}), 3.59(\mathrm{~d}, J=10.7 \mathrm{~Hz}, 2 \mathrm{H}), 3.31(\mathrm{~s}, 3 \mathrm{H}), 2.75$ (s, 3H), 2.77-2.67 (m, 3H), 2.27 (q, $J=12.5 \mathrm{~Hz}, 2 \mathrm{H}), 2.14-1.92$ $(\mathrm{m}, 4 \mathrm{H}), 1.92-1.60(\mathrm{~m}, 8 \mathrm{H}), 0.87(\mathrm{t}, J=7.6 \mathrm{~Hz}, 3 \mathrm{H})$.

(R)-4-((8-Cyclopentyl-7-ethyl-5-methyl-6-oxo-5,6,7,8-tetrahydropteridin-2-yl)amino)-3-isobutoxy- $N$-(1-methylpiperidin-4-yl)benzamide (16b). 16b was synthesized in $28 \%$ yield (white solid, 7.0 $\mathrm{mg}, 12 \mu \mathrm{mol})$ according to the same procedure as $16 \mathrm{~h}$, from $15 \mathrm{a}(13$ $\mathrm{mg}, 44 \mu \mathrm{mol})$ and $5 \mathrm{a}(14 \mathrm{mg}, 44 \mu \mathrm{mol})$. HRMS (ESI +ve): found $[\mathrm{M}]^{+}$564.3652, $\left[\mathrm{C}_{31} \mathrm{H}_{45} \mathrm{~N}_{7} \mathrm{O}_{3}\right]^{+}$requires 564.3657; $[\alpha]_{\mathrm{D}}^{20.8}:-31.2(c$ $1.0, \mathrm{MeOH}) ; \delta_{\mathrm{H}}\left(500 \mathrm{MHz}, \mathrm{CDCl}_{3}\right): 8.55(\mathrm{~d}, J=8.4 \mathrm{~Hz}, 1 \mathrm{H}), 7.68$ $(\mathrm{s}, 1 \mathrm{H}), 7.67(\mathrm{~s}, 1 \mathrm{H}), 7.40(\mathrm{~d}, J=1.6 \mathrm{~Hz}, 1 \mathrm{H}), 7.22(\mathrm{dd}, J=8.4,1.6$ $\mathrm{Hz}, 1 \mathrm{H}), 6.50(\mathrm{~d}, J=6.9 \mathrm{~Hz}, 1 \mathrm{H}), 4.40-4.32(\mathrm{~m}, 1 \mathrm{H}), 4.23(\mathrm{dd}, J=$ 7.4, $3.3 \mathrm{~Hz}, 1 \mathrm{H}), 4.22-4.17(\mathrm{~m}, 1 \mathrm{H}), 3.90(\mathrm{~d}, J=6.3 \mathrm{~Hz}, 2 \mathrm{H}), 3.41$ $(\mathrm{d}, J=10.4 \mathrm{~Hz}, 2 \mathrm{H}), 3.33(\mathrm{~s}, 3 \mathrm{H}), 2.68(\mathrm{t}, J=8.0 \mathrm{~Hz}, 2 \mathrm{H}), 2.33(\mathrm{~s}$, $3 \mathrm{H}), 2.26-1.65(\mathrm{~m}, 15 \mathrm{H}), 1.09(\mathrm{~d}, J=6.6 \mathrm{~Hz}, 6 \mathrm{H}), 0.87(\mathrm{t}, J=7.4$ $\mathrm{Hz}, 3 \mathrm{H})$.

(R)-4-((8-Cyclopentyl-7-ethyl-5-methyl-6-oxo-5,6,7,8-tetrahydropteridin-2-yl)amino)-3-ethoxy-N-(1-methylpiperidin-4-yl)benzamide (16c). 16c was synthesized in $24 \%$ yield (white solid, 13 $\mathrm{mg}, 24 \mu \mathrm{mol})$ according to the same procedure as $16 \mathrm{~h}$, from $15 \mathrm{a}(30$ $\mathrm{mg}, 102 \mu \mathrm{mol})$ and $\mathbf{5 b}(28 \mathrm{mg}, 102 \mu \mathrm{mol})$. HRMS (ESI $+\mathrm{ve})$ : found $[\mathrm{M}]^{+}$536.3345, $\left[\mathrm{C}_{29} \mathrm{H}_{41} \mathrm{~N}_{7} \mathrm{O}_{3}\right]^{+}$requires 536.3349; $[\alpha]_{\mathrm{D}}^{21.8}:-62.3(c$ 1.0, $\mathrm{MeOH}) ; \delta_{\mathrm{H}}\left(500 \mathrm{MHz}, \mathrm{CDCl}_{3}\right): 8.55(\mathrm{~d}, J=8.2 \mathrm{~Hz}, 1 \mathrm{H}), 7.73$ $(\mathrm{s}, 1 \mathrm{H}), 7.68(\mathrm{~s}, 1 \mathrm{H}), 7.41(\mathrm{~d}, J=1.9 \mathrm{~Hz}, 1 \mathrm{H}), 7.35(\mathrm{dd}, J=8.3,1.9$ $\mathrm{Hz}, 1 \mathrm{H}), 6.56(\mathrm{~s}, 1 \mathrm{H}), 4.52-4.44(\mathrm{~m}, 1 \mathrm{H}), 4.28-4.18(\mathrm{~m}, 4 \mathrm{H}), 3.50$ $(\mathrm{d}, J=10.4 \mathrm{~Hz}, 2 \mathrm{H}), 3.34(\mathrm{~s}, 3 \mathrm{H}), 2.72-2.64(\mathrm{~m}, 2 \mathrm{H}), 2.74(\mathrm{~s}, 3 \mathrm{H})$, $2.20-1.97(\mathrm{~m}, 6 \mathrm{H}), 1.93-1.68(\mathrm{~m}, 8 \mathrm{H}), 1.51(\mathrm{t}, J=6.9 \mathrm{~Hz}, 3 \mathrm{H})$, $0.88(\mathrm{t}, J=7.4 \mathrm{~Hz}, 3 \mathrm{H})$.

(S)-4-((8-Cyclopentyl-7-ethyl-5-methyl-6-oxo-5,6,7,8-tetrahydropteridin-2-yl)amino)-3-ethoxy-N-(1-methylpiperidin-4-yl)benzamide (16d). 16d was synthesized in $42 \%$ yield (white solid, 23 $\mathrm{mg}, 43 \mu \mathrm{mol})$ according to the same procedure as $16 \mathbf{h}$, from $15 \mathbf{b}(30$ $\mathrm{mg}, 102 \mu \mathrm{mol})$ and $\mathbf{5 b}(28 \mathrm{mg}, 102 \mu \mathrm{mol})$. HRMS (ESI $+\mathrm{ve})$ : found $[\mathrm{M}]^{+}$536.3329, $\left[\mathrm{C}_{29} \mathrm{H}_{41} \mathrm{~N}_{7} \mathrm{O}_{3}\right]^{+}$requires 536.3349; $[\alpha]_{\mathrm{D}}^{21.8}:+51.9(c$ $1.0, \mathrm{MeOH}) ; \delta_{\mathrm{H}}\left(500 \mathrm{MHz}, \mathrm{CDCl}_{3}\right): 8.55(\mathrm{~d}, J=8.2 \mathrm{~Hz}, 1 \mathrm{H}), 7.89$ (s, 1H), $7.67(\mathrm{~s}, 1 \mathrm{H}), 7.45(\mathrm{~d}, J=1.9 \mathrm{~Hz}, 1 \mathrm{H}), 7.35$ (dd, $J=8.3,1.9$ $\mathrm{Hz}, 1 \mathrm{H}), 6.56(\mathrm{~s}, 1 \mathrm{H}), 4.52-4.44(\mathrm{~m}, 1 \mathrm{H}), 4.33-4.23(\mathrm{~m}, 2 \mathrm{H}), 4.20$ $(\mathrm{q}, J=6.9 \mathrm{~Hz}, 2 \mathrm{H}), 3.50(\mathrm{~d}, J=10.4 \mathrm{~Hz}, 2 \mathrm{H}), 3.33(\mathrm{~s}, 3 \mathrm{H}), 2.72-$ $2.64(\mathrm{~m}, 2 \mathrm{H}), 2.78(\mathrm{~s}, 3 \mathrm{H}), 2.20-1.97(\mathrm{~m}, 6 \mathrm{H}), 1.93-1.68(\mathrm{~m}, 8 \mathrm{H})$, $1.50(\mathrm{t}, J=6.9 \mathrm{~Hz}, 3 \mathrm{H}), 0.88(\mathrm{t}, J=7.6 \mathrm{~Hz}, 3 \mathrm{H})$.

4-((8-Cyclopentyl-5-methyl-6-oxo-5,6,7,8-tetrahydropteridin-2yl)amino)-3-ethoxy- $N$-(1-methylpiperidin-4-yl)benzamide (16e). 16e was synthesized in $6.6 \%$ yield (white solid, $2.0 \mathrm{mg}, 3.9 \mu \mathrm{mol}$ ) according to the same procedure as $16 \mathrm{~h}$, from $15 \mathrm{c}(16 \mathrm{mg}, 60 \mu \mathrm{mol})$ and $\mathbf{5 b}(16 \mathrm{mg}, 57 \mu \mathrm{mol})$. HRMS (ESI +ve): found $[\mathrm{M}]^{+}$508.3028, $\left[\mathrm{C}_{29} \mathrm{H}_{41} \mathrm{~N}_{7} \mathrm{O}_{3}\right]^{+}$requires 508.3031; $\delta_{\mathrm{H}}\left(500 \mathrm{MHz}, \mathrm{CDCl}_{3}\right): 8.53(\mathrm{~d}, J$ $=8.4 \mathrm{~Hz}, 1 \mathrm{H}), 7.69(\mathrm{~s}, 1 \mathrm{H}), 7.63(\mathrm{~s}, 1 \mathrm{H}), 7.41(\mathrm{~d}, J=1.8 \mathrm{~Hz}, 1 \mathrm{H})$, $7.23(\mathrm{dd}, J=8.4,1.8 \mathrm{~Hz}, 1 \mathrm{H}), 5.91(\mathrm{~s}, 1 \mathrm{H}), 5.16$ (quin, $J=8.1 \mathrm{~Hz}$, H3), $4.22(\mathrm{q}, J=7.6 \mathrm{~Hz}, 2 \mathrm{H}), 4.09(\mathrm{~s}, 2 \mathrm{H}), 4.03-3.94(\mathrm{~m}, 1 \mathrm{H}), 3.33$ $(\mathrm{s}, 3 \mathrm{H}), 2.88-2.80(\mathrm{~m}, 2 \mathrm{H}), 2.32(\mathrm{~s}, 3 \mathrm{H}), 2.20-2.15(\mathrm{~m}, 2 \mathrm{H}), 2.06$ $(\mathrm{m}, 2 \mathrm{H}), 2.01-1.93(\mathrm{~m}, 2 \mathrm{H}), 1.84-1.58(\mathrm{~m}, 8 \mathrm{H}), 1.52(\mathrm{t}, J=7.6 \mathrm{~Hz}$, $3 \mathrm{H})$.
(R)-4-((8-(3-Bromobenzyl)-7-ethyl-5-methyl-6-oxo-5,6,7,8-tetrahydropteridin-2-yl)amino)-3-ethoxy- $N$-(1-methylpiperidin-4-yl)benzamide (16f). $16 \mathrm{f}$ was synthesized in $53 \%$ yield (white solid, 55 $\mathrm{mg}, 86 \mu \mathrm{mol})$ according to the same procedure as $16 \mathrm{~h}$, from $15 \mathrm{~d}$ (65 $\mathrm{mg}, 164 \mu \mathrm{mol})$ and $\mathbf{5 b}(46 \mathrm{mg}, 164 \mu \mathrm{mol})$. HRMS (ESI +ve): found $[\mathrm{M}]^{+}$622.2302, $\left[\mathrm{C}_{31} \mathrm{H}_{38} \mathrm{BrN}_{7} \mathrm{O}_{3}\right]^{+}$requires 636.2298; $[\alpha]_{\mathrm{D}}^{22.1}:+5.1(c$ $1.0, \mathrm{MeOH}) ; \delta_{\mathrm{H}}\left(500 \mathrm{MHz}, \mathrm{CDCl}_{3}\right): 8.23(\mathrm{~d}, J=8.5 \mathrm{~Hz}, 1 \mathrm{H}), 7.74$ $(\mathrm{s}, 1 \mathrm{H}), 7.63(\mathrm{~s}, 1 \mathrm{H}), 7.50(\mathrm{t}, J=1.6 \mathrm{~Hz}, 1 \mathrm{H}), 7.44(\mathrm{dt}, J=7.6,1.6$ $\mathrm{Hz}, 1 \mathrm{H}), 7.42(\mathrm{~d}, J=1.9 \mathrm{~Hz}, 1 \mathrm{H}), 7.28-7.20(\mathrm{~m}, 2 \mathrm{H}), 7.14(\mathrm{dd}, J=$ $8.5,1.9 \mathrm{~Hz}, 1 \mathrm{H}), 5.96(\mathrm{~d}, J=7.9 \mathrm{~Hz}, 1 \mathrm{H}), 5.51(\mathrm{~d}, J=15.8 \mathrm{~Hz}, 1 \mathrm{H})$, $4.23-4.16(\mathrm{~m}, 4 \mathrm{H}), 4.04-3.94(\mathrm{~m}, 1 \mathrm{H}), 3.38(\mathrm{~s}, 3 \mathrm{H}), 2.76-2.67(\mathrm{~m}$, $2 \mathrm{H}), 2.31(\mathrm{~s}, 3 \mathrm{H}), 2.17(\mathrm{t}, J=10.9 \mathrm{~Hz}, 2 \mathrm{H}), 2.09-2.01(\mathrm{~m}, 2 \mathrm{H})$, $2.00-1.93(\mathrm{~m}, 1 \mathrm{H}), 1.89-1.80(\mathrm{~m}, 1 \mathrm{H}), 1.63-1.58(\mathrm{~m}, 2 \mathrm{H}) 1.49(\mathrm{t}, J$ $=7.1 \mathrm{~Hz}, 3 \mathrm{H}), 0.87(\mathrm{t}, J=7.4 \mathrm{~Hz}, 3 \mathrm{H})$.

(R)-4-((8-Benzyl-7-ethyl-5-methyl-6-oxo-5,6,7,8-tetrahydropteridin-2-yl)amino)-3-ethoxy-N-(1-methylpiperidin-4-yl)benzamide (16g). $16 \mathrm{~g}$ was synthesized in $46 \%$ yield (pale yellow solid, $4.0 \mathrm{mg}$, $7.2 \mu \mathrm{mol})$ according to the same procedure as $\mathbf{1 6} \mathbf{i}$, from $16 \mathrm{f}(10 \mathrm{mg}$, $16 \mu \mathrm{mol})$. HRMS (ESI +ve): found $[\mathrm{M}]^{+} 558.3161,\left[\mathrm{C}_{31} \mathrm{H}_{39} \mathrm{~N}_{7} \mathrm{O}_{3}\right]^{+}$ requires 558.3193; $[\alpha]_{\mathrm{D}}^{21.9}:-9.7(c 1.0, \mathrm{MeOH}) ; \delta_{\mathrm{H}}(500 \mathrm{MHz}$, $\left.\mathrm{CDCl}_{3}\right): 8.45(\mathrm{~d}, J=8.5 \mathrm{~Hz}, 1 \mathrm{H}), 7.75(\mathrm{~s}, 1 \mathrm{H}), 7.73(\mathrm{~s}, 1 \mathrm{H}), 7.42(\mathrm{~d}$, $J=1.6 \mathrm{~Hz}, 1 \mathrm{H}), 7.40-7.29(\mathrm{~m}, 6 \mathrm{H}), 6.61(\mathrm{~d}, J=8.2 \mathrm{~Hz}, 1 \mathrm{H}), 5.66$ $(\mathrm{d}, J=15.1 \mathrm{~Hz}, 1 \mathrm{H}), 4.28-4.19(\mathrm{~m}, 4 \mathrm{H}), 4.18(\mathrm{dd}, J=6.3,3.5 \mathrm{~Hz}$, $1 \mathrm{H}), 3.48(\mathrm{~d}, J=11.7 \mathrm{~Hz}, 2 \mathrm{H}), 3.37(\mathrm{~s}, 3 \mathrm{H}), 2.80-2.72(\mathrm{~m}, 2 \mathrm{H})$, $2.73(\mathrm{~s}, 3 \mathrm{H}), 2.20-2.12(\mathrm{~m}, 4 \mathrm{H}), 2.01-1.92(\mathrm{~m}, 1 \mathrm{H}), 1.91-1.82(\mathrm{~m}$, $1 \mathrm{H}), 1.51(\mathrm{t}, J=6.9 \mathrm{~Hz}, 3 \mathrm{H}), 0.87(\mathrm{t}, J=7.9 \mathrm{~Hz}, 3 \mathrm{H})$.

(R)-8-(3-Bromobenzyl)-2-((2-ethoxy-4-(1-methylpiperidin-4-yl)phenyl)amino)-7-ethyl-5-methyl-7,8-dihydropteridin-6(5H)-one (16h). 16h was synthesized in $29 \%$ yield (white solid, $30 \mathrm{mg}, 51$ $\mu \mathrm{mol})$ according to the same procedure as $16 \mathrm{a}$, from $15 \mathrm{~d}(69 \mathrm{mg}, 174$ $\mu \mathrm{mol}$ ) and 10a (39 mg, $166 \mu \mathrm{mol})$. HRMS (ESI +ve): found $[\mathrm{M}]^{+}$ 593.2209, $\left[\mathrm{C}_{30} \mathrm{H}_{38} \mathrm{BrN}_{6} \mathrm{O}_{2}\right]^{+}$requires 593.2234; $[\alpha]_{\mathrm{D}}^{23.7}:+1.7(c$ 1.0, $\mathrm{MeOH}) ; \delta_{\mathrm{H}}\left(500 \mathrm{MHz}, \mathrm{CDCl}_{3}\right): 8.13(\mathrm{~s}, 1 \mathrm{H}), 7.96(\mathrm{~d}, J=8.2 \mathrm{~Hz}$, $1 \mathrm{H}), 7.68(\mathrm{~s}, 1 \mathrm{H}), 7.46-7.42(\mathrm{~m}, 2 \mathrm{H}), 7.23-7.20(\mathrm{~m}, 2 \mathrm{H}), 6.74-$ $6.70(\mathrm{~m}, 2 \mathrm{H}), 5.51(\mathrm{~d}, J=15.5 \mathrm{~Hz}, 1 \mathrm{H}), 4.19-4.13(\mathrm{~m}, 2 \mathrm{H}), 4.11(\mathrm{q}$, $J=6.9 \mathrm{~Hz}, 2 \mathrm{H}), 3.67-3.63(\mathrm{~m}, 2 \mathrm{H}), 3.35(\mathrm{~s}, 3 \mathrm{H}), 2.85-2.75(\mathrm{~m}$, $2 \mathrm{H}), 2.82(\mathrm{~s}, 3 \mathrm{H}), 2.70-2.61(\mathrm{~m}, 1 \mathrm{H}), 2.28(\mathrm{q}, J=12.3 \mathrm{~Hz}, 2 \mathrm{H})$, 2.05-1.94 (m, 3H), 1.90-1.80 (m, $1 \mathrm{H}), 1.47(\mathrm{t}, J=6.9 \mathrm{~Hz}, 3 \mathrm{H})$, $0.85(\mathrm{t}, J=7.6 \mathrm{~Hz}, 3 \mathrm{H})$.

(R)-8-Benzyl-2-((2-ethoxy-4-(1-methylpiperidin-4-yl)phenyl)amino)-7-ethyl-5-methyl-7,8-dihydropteridin-6(5H)-one (16i). A solution of $16 \mathrm{~h}(14 \mathrm{mg}, 24 \mu \mathrm{mol})$ and $10 \% \mathrm{Pd} \cdot \mathrm{C}(1.5 \mathrm{mg}, 14$ $\mu \mathrm{mol})$ in $\mathrm{MeOH}(0.01 \mathrm{M})$ was stirred at $\mathrm{rt}$ under a hydrogen atmosphere $(1 \mathrm{~atm})$ for $1 \mathrm{~h}$. The mixture was filtered through celite and washed with $\mathrm{MeOH}$. The solvent was removed in vacuo, and the residue was purified by reverse phase column chromatography (water $/ \mathrm{MeOH}, 0-100 \%$ ) to give the title compound $16 \mathbf{i}$ as a white solid $(5.0 \mathrm{mg}, 9.7 \mu \mathrm{mol}, 41 \%)$. HRMS (ESI +ve): found $[\mathrm{M}]^{+}$ 515.3114, $\left[\mathrm{C}_{30} \mathrm{H}_{40} \mathrm{~N}_{6} \mathrm{O}_{2}\right]^{+}$requires 515.3129; $[\alpha]_{\mathrm{D}}^{23.7}:+24.2(c$ l.0, $\mathrm{MeOH}) ; \delta_{\mathrm{H}}\left(500 \mathrm{MHz}, \mathrm{CDCl}_{3}\right): 8.22(\mathrm{~d}, J=8.8 \mathrm{~Hz}, 1 \mathrm{H}), 7.68(\mathrm{~s}$, $1 \mathrm{H}), 7.58(\mathrm{~s}, 1 \mathrm{H}), 7.37-7.29(\mathrm{~m}, 5 \mathrm{H}), 6.72(\mathrm{~d}, J=1.6 \mathrm{~Hz}, 1 \mathrm{H}), 6.70$ $(\mathrm{dd}, J=8.2,1.6 \mathrm{~Hz}, 1 \mathrm{H}), 5.62(\mathrm{~d}, J=15.1 \mathrm{~Hz}, 1 \mathrm{H}), 4.18-4.15(\mathrm{~m}$, $3 \mathrm{H}), 4.11(\mathrm{q}, J=7.2 \mathrm{~Hz}, 2 \mathrm{H}), 3.64(\mathrm{~d}, J=10.4 \mathrm{~Hz}, 2 \mathrm{H}), 3.34(\mathrm{~s}, 3 \mathrm{H})$, $2.73(\mathrm{~s}, 3 \mathrm{H}), 2.73-2.58(\mathrm{~m}, 3 \mathrm{H}), 2.25-2.15(\mathrm{~m}, 2 \mathrm{H}), 2.02-1.92(\mathrm{~m}$, $3 \mathrm{H}), 1.90-1.81(\mathrm{~m}, 1 \mathrm{H}), 1.48(\mathrm{t}, J=6.9 \mathrm{~Hz}, 3 \mathrm{H}), 0.85(\mathrm{t}, J=7.4 \mathrm{~Hz}$, $3 \mathrm{H})$.

(R)-2-((2-Ethoxy-4-(1-methylpiperidin-4-yl)phenyl)amino)-7ethyl-5-methyl-8-((3-methylthiophen-2-yl)methyl)-7,8-dihydropteridin-6(5H)-one (16j). 16j was synthesized in $9.4 \%$ yield (yellow solid, $6.0 \mathrm{mg}, 11 \mu \mathrm{mol}$ ) according to the same procedure as $16 \mathrm{~h}$, from $15 \mathrm{e}$ $(40 \mathrm{mg}, 120 \mu \mathrm{mol})$ and $10 \mathrm{a}(26 \mathrm{mg}, 110 \mu \mathrm{mol})$. HRMS (ESI +ve): found $[\mathrm{M}]^{+} 535.2828,\left[\mathrm{C}_{29} \mathrm{H}_{39} \mathrm{~N}_{6} \mathrm{O}_{2} \mathrm{~S}\right]^{+}$requires 535.2850; $[\alpha]_{\mathrm{D}}^{23.5}$ : $+7.6(c 1.0, \mathrm{MeOH}) ; \delta_{\mathrm{H}}\left(500 \mathrm{MHz}, \mathrm{CDCl}_{3}\right): 8.31(\mathrm{~d}, J=8.2 \mathrm{~Hz}$, $1 \mathrm{H}), 7.67(\mathrm{~s}, 1 \mathrm{H}), 7.64(\mathrm{~s}, 1 \mathrm{H}), 7.15(\mathrm{~d}, J=5.0 \mathrm{~Hz}, 1 \mathrm{H}), 6.83(\mathrm{~d}, J=$ $5.0 \mathrm{~Hz}, 1 \mathrm{H}), 6.78(\mathrm{dd}, J=8.2,1.6 \mathrm{~Hz}, 1 \mathrm{H}), 6.73(\mathrm{~d}, J=1.6 \mathrm{~Hz}, 1 \mathrm{H})$, $5.63(\mathrm{~d}, J=15.1 \mathrm{~Hz}, 1 \mathrm{H}), 4.33(\mathrm{~d}, J=15.1 \mathrm{~Hz}, 1 \mathrm{H}), 4.19(\mathrm{dd}, J=6.5$, $3.6 \mathrm{~Hz}, 1 \mathrm{H}), 4.13(\mathrm{q}, J=6.9 \mathrm{~Hz}, 2 \mathrm{H}), 3.57(\mathrm{~d}, J=9.1 \mathrm{~Hz}, 2 \mathrm{H}), 3.32$ $(\mathrm{s}, 3 \mathrm{H}), 2.76-2.60(\mathrm{~m}, 6 \mathrm{H}), 2.25(\mathrm{~s}, 3 \mathrm{H}), 2.24-2.15(\mathrm{~m}, 2 \mathrm{H}), 2.02-$ $1.91(\mathrm{~m}, 3 \mathrm{H}), 1.88-1.79(\mathrm{~m}, 1 \mathrm{H}), 1.49(\mathrm{t}, J=6.9 \mathrm{~Hz}, 3 \mathrm{H}), 0.85(\mathrm{t}, J$ $=7.4 \mathrm{~Hz}, 3 \mathrm{H})$. 
(R)-2-((2-Ethoxy-4-(1-methylpiperidin-4-yl)phenyl)amino)-7ethyl-5-methyl-8-((4-methylthiophen-2-yl)methyl)-7,8-dihydropteridin-6(5H)-one (16k). 16k was synthesized in $23 \%$ yield (yellow solid, $20 \mathrm{mg}, 37 \mu \mathrm{mol}$ ) according to the same procedure as $16 \mathbf{h}$, from $15 \mathrm{f}$ (55 mg, $163 \mu \mathrm{mol}$ ) and 10a (36 mg, $155 \mu \mathrm{mol})$. HRMS (ESI +ve): found $[\mathrm{M}]^{+}$535.2835, $\left[\mathrm{C}_{29} \mathrm{H}_{39} \mathrm{~N}_{6} \mathrm{O}_{2} \mathrm{~S}\right]^{+}$requires 535.2850; $[\alpha]_{\mathrm{D}}^{22.6}$ : +7.6 (c 1.0, MeOH); $\delta_{\mathrm{H}}\left(500 \mathrm{MHz}, \mathrm{CDCl}_{3}\right): 8.34(\mathrm{~d}, J=8.2 \mathrm{~Hz}$, $1 \mathrm{H}), 7.67(\mathrm{~s}, 1 \mathrm{H}), 7.45(\mathrm{~s}, 1 \mathrm{H}), 7.14(\mathrm{~d}, J=1.3 \mathrm{~Hz}, 1 \mathrm{H}), 6.85(\mathrm{~s}$, $1 \mathrm{H}), 6.82-6.76(\mathrm{~m}, 3 \mathrm{H}), 5.61(\mathrm{~d}, J=15.5 \mathrm{~Hz}, 1 \mathrm{H}), 4.34(\mathrm{~d}, J=15.5$ $\mathrm{Hz}, 1 \mathrm{H}), 4.25(\mathrm{dd}, J=6.3,3.5 \mathrm{~Hz} 1 \mathrm{H}), 4.11(\mathrm{q}, J=6.9 \mathrm{~Hz}, 2 \mathrm{H})$, $3.35-3.29(\mathrm{~m}, 5 \mathrm{H}), 2.60(\mathrm{~s}, 3 \mathrm{H}), 2.58-2.46(\mathrm{~m}, 3 \mathrm{H}), 2.22(\mathrm{~s}, 3 \mathrm{H})$, $2.20-2.12(\mathrm{~m}, 2 \mathrm{H}), 2.00-1.92(\mathrm{~m}, 3 \mathrm{H}), 1.89-1.80(\mathrm{~m}, 1 \mathrm{H}), 1.48(\mathrm{t}$, $J=6.9 \mathrm{~Hz}, 3 \mathrm{H}), 0.85(\mathrm{t}, J=7.6 \mathrm{~Hz}, 3 \mathrm{H})$.

(R)-2-((2-Ethoxy-4-(1-methylpiperidin-4-yl)phenyl)amino)-7ethyl-5-methyl-8-((5-methylthiophen-2-yl)methyl)-7,8-dihydropteridin-6(5H)-one (16I). 161 was synthesized in $25 \%$ yield (yellow oil, 18 $\mathrm{mg}, 34 \mu \mathrm{mol}$ ) according to the same procedure as $16 \mathrm{~h}$, from $15 \mathrm{~g}(45$ $\mathrm{mg}, 134 \mu \mathrm{mol})$ and $10 \mathrm{a}(30 \mathrm{mg}, 127 \mu \mathrm{mol})$. HRMS (ESI +ve): found $[\mathrm{M}]^{+}$535.2833, $\left[\mathrm{C}_{29} \mathrm{H}_{39} \mathrm{~N}_{6} \mathrm{O}_{2} \mathrm{~S}\right]^{+}$requires 535.2850; $[\alpha]_{\mathrm{D}}^{23.6}:+11.1(c$ 1.0, $\mathrm{MeOH}) ; \delta_{\mathrm{H}}\left(500 \mathrm{MHz}, \mathrm{CDCl}_{3}\right): 8.34(\mathrm{~d}, J=8.2 \mathrm{~Hz}, 1 \mathrm{H}), 7.67$ $(\mathrm{s}, 1 \mathrm{H}), 7.63(\mathrm{~s}, 1 \mathrm{H}), 6.83(\mathrm{~d}, J=3.2 \mathrm{~Hz}, 1 \mathrm{H}), 6.79(\mathrm{dd}, J=8.2,1.9$ $\mathrm{Hz}, 1 \mathrm{H}), 6.75(\mathrm{~d}, J=1.8 \mathrm{~Hz}, 1 \mathrm{H}), 6.60(\mathrm{~d}, J=3.2 \mathrm{~Hz}, 1 \mathrm{H}), 5.57(\mathrm{~d}, J$ $=15.5 \mathrm{~Hz}, 1 \mathrm{H}), 4.43(\mathrm{~d}, J=15.5 \mathrm{~Hz}, 1 \mathrm{H}), 4.26(\mathrm{dd}, J=6.2,3.6 \mathrm{~Hz}$, $1 \mathrm{H}), 4.14(\mathrm{q}, J=6.9 \mathrm{~Hz}, 2 \mathrm{H}), 3.57(\mathrm{~d}, J=10.1 \mathrm{~Hz}, 2 \mathrm{H}), 3.32(\mathrm{~s}, 3 \mathrm{H})$, $2.73(\mathrm{~s}, 3 \mathrm{H}), 2.73-2.61(\mathrm{~m}, 3 \mathrm{H}), 2.44(\mathrm{~s}, 3 \mathrm{H}), 2.25-2.15(\mathrm{~m}, 2 \mathrm{H})$, 2.02-1.92 (m, 3H), $1.89-1.80(\mathrm{~m}, 1 \mathrm{H}), 1.60(\mathrm{t}, J=6.9 \mathrm{~Hz}, 3 \mathrm{H})$, $0.84(\mathrm{t}, J=7.4 \mathrm{~Hz}, 3 \mathrm{H})$.

(R)-Methyl 2-((2,4-Dimethoxybenzyl)amino)butanoate (17). 17 was synthesized in $97 \%$ yield (yellow oil, $27.0 \mathrm{~g}, 101 \mathrm{mmol}$ ) according to the same procedure as $\mathbf{1 2 d}$, from $(R)$-methyl 2 -aminobutanoate 11a ( $\mathrm{HCl}$ salt, $16.0 \mathrm{~g}, 104 \mathrm{mmol}$ ) and 2,4-dimethoxybenzaldehye $(17.3 \mathrm{~g}, 101 \mathrm{mmol})$. HRMS (ESI +ve): found $[\mathrm{M}]^{+}$268.1541, $\left[\mathrm{C}_{14} \mathrm{H}_{21} \mathrm{NO}_{4}\right]^{+}$requires 268.1543; $[\alpha]_{\mathrm{D}}^{23.9}:+11.8\left(\right.$ c 1.0, MeOH); $\delta_{\mathrm{H}}$ $\left(500 \mathrm{MHz}, \mathrm{CDCl}_{3}\right): 7.13(\mathrm{~d}, J=7.9 \mathrm{~Hz}, 1 \mathrm{H}), 6.45-6.41(\mathrm{~m}, 2 \mathrm{H})$, $3.81(\mathrm{~s}, 3 \mathrm{H}), 3.80(\mathrm{~s}, 3 \mathrm{H}), 3.71(\mathrm{~d}, J=13.2 \mathrm{~Hz}, 1 \mathrm{H}), 3.67-3.74(\mathrm{~m}$, $4 \mathrm{H}), 3.21(\mathrm{t}, J=6.5 \mathrm{~Hz}, 1 \mathrm{H}), 1.73-1.63(\mathrm{~m}, 2 \mathrm{H}), 0.91(\mathrm{t}, J=7.4 \mathrm{~Hz}$, $3 \mathrm{H})$.

(R)-Methyl 2-((2-Chloro-5-nitropyrimidin-4-yl)(2,4dimethoxybenzyl)amino)butanoate (18). 18 was synthesized in $78 \%$ yield (yellow gum, $33.4 \mathrm{~g}, 78.6 \mathrm{mmol}$ ) according to the same procedure as 13d, from $17(27.0 \mathrm{~g}, 101 \mathrm{mmol})$ and 2,4-dichloro-5nitropyrimidine $15(21.6 \mathrm{~g}, 111 \mathrm{mmol})$. HRMS (ESI +ve): found $[\mathrm{M}]^{+} 425.1211,\left[\mathrm{C}_{18} \mathrm{H}_{21} \mathrm{ClN}_{4} \mathrm{O}_{6}\right]^{+}$requires 425.1222; $[\alpha]_{\mathrm{D}}^{23.7}:-6.9(c$ 1.0, $\mathrm{MeOH}) ; \delta_{\mathrm{H}}\left(500 \mathrm{MHz}, \mathrm{CDCl}_{3}\right): 8.65(\mathrm{~s}, 1 \mathrm{H}), 7.04(\mathrm{~d}, J=8.2$ $\mathrm{Hz}, 1 \mathrm{H}), 6.40-6.37(\mathrm{~m}, 2 \mathrm{H}), 4.47-4.43(\mathrm{~m}, 2 \mathrm{H}), 4.40(\mathrm{~d}, J=16.1$ $\mathrm{Hz}, 1 \mathrm{H}), 3.79(\mathrm{~s}, 3 \mathrm{H}), 3.71(\mathrm{~s}, 3 \mathrm{H}), 3.62(\mathrm{~s}, 3 \mathrm{H}), 2.28-2.18(\mathrm{~m}, 1 \mathrm{H})$, 2.07-1.99 (m, 1H), $1.05(\mathrm{t}, J=7.4 \mathrm{~Hz}, 3 \mathrm{H})$.

(R)-2-Chloro-8-(2,4-dimethoxybenzyl)-7-ethyl-7,8-dihydropteridin-6(5H)-one (19). A solution of 18 (13.0 g, $30.6 \mathrm{mmol}), 10 \% \mathrm{Pt} \cdot \mathrm{C}$ (597 mg, $3.06 \mathrm{mmol})$, and $\mathrm{VO}(\mathrm{acac})_{2}(650 \mathrm{mg}, 2.45 \mathrm{mmol})$ in THF $(0.3 \mathrm{M})$ was stirred at $\mathrm{rt}$ under a hydrogen atmosphere $(1 \mathrm{~atm})$ for 48 h. The mixture was filtered through celite, and the solvent was removed in vacuo to give 19 as a brown solid $(11.0 \mathrm{~g}, 30.3 \mathrm{mmol}$, 98\%). HRMS (ESI +ve): found $[\mathrm{M}]^{+} 363.1198,\left[\mathrm{C}_{17} \mathrm{H}_{19} \mathrm{ClN}_{4} \mathrm{O}_{3}\right]^{+}$ requires 363.1218; $[\alpha]_{\mathrm{D}}^{23.4}:+15.2(c 1.0, \mathrm{MeOH}) ; \delta_{\mathrm{H}}(500 \mathrm{MHz}$, $\left.\mathrm{CDCl}_{3}\right)$ : $9.72(1 \mathrm{H}), 7.65(\mathrm{~s}, 1 \mathrm{H}), 7.30(\mathrm{~d}, J=9.1 \mathrm{~Hz}, 1 \mathrm{H}), 6.47-6.45$ $(\mathrm{m}, 2 \mathrm{H}), 5.35(\mathrm{~d}, J=14.7 \mathrm{~Hz}, 2 \mathrm{H}), 4.28(\mathrm{dd}, J=5.4,4.4 \mathrm{~Hz}, 1 \mathrm{H})$, $4.20(\mathrm{~d}, J=14.7 \mathrm{~Hz}, 1 \mathrm{H}), 3.80(\mathrm{~s}, 6 \mathrm{H}), 2.03-1.94(\mathrm{~m}, 2 \mathrm{H}), 0.94(\mathrm{t}, J$ $=7.3 \mathrm{~Hz}, 3 \mathrm{H})$.

(R)-2-Chloro-8-(2,4-dimethoxybenzyl)-7-ethyl-5-methyl-7,8-dihydropteridin-6(5H)-one (20). 20 was synthesized in $86 \%$ yield (yellow oil, $9.66 \mathrm{~g}, 25.6 \mathrm{mmol}$ ) according to the same procedure as 15d, from 19 (10.8 g, $29.8 \mathrm{mmol})$ and methyl iodide $(2.42 \mathrm{~mL}, 38.7$ mmol). HRMS (ESI +ve): found $[\mathrm{M}]^{+} 377.1366,\left[\mathrm{C}_{18} \mathrm{H}_{21} \mathrm{ClN}_{4} \mathrm{O}_{3}\right]^{+}$ requires $377.1375 ;[\alpha]_{\mathrm{D}}^{23.7}:+35.3(c 1.0, \mathrm{MeOH}) ; \delta_{\mathrm{H}}(500 \mathrm{MHz}$, $\left.\mathrm{CDCl}_{3}\right): 7.62(\mathrm{~s}, 1 \mathrm{H}), 7.32(\mathrm{~d}, J=8.8 \mathrm{~Hz}, 1 \mathrm{H}), 6.47-6.45(\mathrm{~m}, 2 \mathrm{H})$, $5.34(\mathrm{~d}, J=14.5 \mathrm{~Hz}, 1 \mathrm{H}), 4.34(\mathrm{dd}, J=6.3,3.8 \mathrm{~Hz}, 1 \mathrm{H}), 4.20(\mathrm{~d}, J=$ $14.7 \mathrm{~Hz}, 1 \mathrm{H}), 3.81(\mathrm{~s}, 6 \mathrm{H}), 3.30(\mathrm{~s}, 3 \mathrm{H}), 1.99-1.85(\mathrm{~m}, 2 \mathrm{H}), 0.85(\mathrm{t}$, $J=7.9 \mathrm{~Hz}, 3 \mathrm{H})$.
(R)-2-Chloro-7-5-methyl-7,8-dihydropteridin-6(5H)-one (21). A solution of $20(5.09 \mathrm{~g}, 13.5 \mathrm{mmol})$ in TFA $(1.3 \mathrm{M})$ was stirred at $80{ }^{\circ} \mathrm{C}$ for $4 \mathrm{~h}$. Upon completion, the reaction was concentrated in vacuo to remove the majority of the TFA. The remaining TFA was quenched with sat. $\mathrm{NaHCO}_{3}$ until pH 7-8 was reached and extracted with $\mathrm{DCM}(\times 3)$. The organic layers were washed with brine, dried over $\mathrm{MgSO} 4$, filtered, and concentrated in vacuo. The residue was purified by Biotage column chromatography (DCM/MeOH, $0-15 \%)$ to give 21 as a brown solid $(2.02 \mathrm{~g}, 8.91 \mathrm{mmol}, 66 \%)$. HRMS (ESI +ve): found $[\mathrm{M}]^{+}$227.0695, $\left[\mathrm{C}_{9} \mathrm{H}_{11} \mathrm{ClN}_{4} \mathrm{O}\right]^{+}$requires 227.0694; $[\alpha]_{\mathrm{D}}^{23.7}:+35.3($ c 1.0, $\mathrm{MeOH}) ; \delta_{\mathrm{H}}\left(500 \mathrm{MHz}, \mathrm{CDCl}_{3}\right): 7.73(\mathrm{~s}, 1 \mathrm{H})$, $6.39(\mathrm{~s}, 1 \mathrm{H}), 4.34(\mathrm{dd}, J=6.3,4.7 \mathrm{~Hz}, 1 \mathrm{H}), 3.34(\mathrm{~s}, 3 \mathrm{H}), 2.03-1.87$ $(\mathrm{m}, 2 \mathrm{H}), 0.99(\mathrm{t}, J=7.4 \mathrm{~Hz}, 3 \mathrm{H})$.

(R)-2-Chloro-8-(3-chlorobenzyl)-7-ethyl-5-methyl-7,8-dihydropteridin-6(5H)-one (22a). To a solution of $21(50 \mathrm{mg}, 0.22 \mathrm{mmol})$ in DMF $(0.2 \mathrm{M})$ was added 1-(bromomethyl)-3-chlorobenzene (36 $\mu \mathrm{L}$, $0.28 \mathrm{mmol})$. The mixture was cooled to $-10{ }^{\circ} \mathrm{C}, \mathrm{NaH}(12 \mathrm{mg}, 0.50$ mmol) was added, and then the mixture was stirred at rt for $18 \mathrm{~h}$. Upon completion, ice was added and the reaction was partitioned between EtOAc and water. The aqueous layer was further extracted with EtOAc $(\times 3)$. The combined organic phases were washed with water $(\times 2)$, dried over $\mathrm{MgSO}_{4}$, filtered, and concentrated in vacuo. The residue was purified by Biotage column chromatography (cHex/ EtOAc, $0-20 \%)$ to give $22 \mathrm{a}$ as an orange solid $(51 \mathrm{mg}, 0.15 \mathrm{mmol}$, $66 \%$ ). HRMS (ESI +ve): found $[\mathrm{M}]^{+} 351.0775,\left[\mathrm{C}_{16} \mathrm{H}_{16} \mathrm{Cl}_{2} \mathrm{~N}_{4} \mathrm{O}\right]^{+}$ requires 351.0774; $[\alpha]_{\mathrm{D}}^{23.6}:-1.4(c 1.0, \mathrm{MeOH}) ; \delta_{\mathrm{H}}(500 \mathrm{MHz}$, $\left.\mathrm{CDCl}_{3}\right): 7.73(\mathrm{~s}, 1 \mathrm{H}), 7.32-7.28(\mathrm{~m}, 3 \mathrm{H}), 7.20-7.18(\mathrm{~m}, 1 \mathrm{H}), 5.62$ $(\mathrm{d}, J=15.1 \mathrm{~Hz}, 1 \mathrm{H}), 4.17(\mathrm{dd}, J=6.2,3.2 \mathrm{~Hz}, 1 \mathrm{H}), 4.08(\mathrm{~d}, J=15.1$ $\mathrm{Hz}, 1 \mathrm{H}), 3.35(\mathrm{~s}, 3 \mathrm{H}), 2.00-1.81(\mathrm{~m}, 3 \mathrm{H}), 0.84(\mathrm{t}, J=7.6 \mathrm{~Hz}, 3 \mathrm{H})$.

(R)-3-((2-Chloro-7-ethyl-5-methyl-6-oxo-6,7-dihydropteridin$8(5 H)$-yl)methyl)benzonitrile (22b). 22b was synthesized in $37 \%$ yield (white solid, $28 \mathrm{mg}, 0.08 \mathrm{mmol}$ ) according to the same procedure as $22 \mathrm{a}$, from $21(50 \mathrm{mg}, 0.22 \mathrm{mmol})$ and 3(bromomethyl)benzonitrile $(35 \mu \mathrm{L}, 0.28 \mathrm{mmol})$. HRMS (ESI +ve): found $[\mathrm{M}]^{+} 341.1112,\left[\mathrm{C}_{17} \mathrm{H}_{16} \mathrm{ClN}_{5} \mathrm{O}\right]^{+}$requires 342.1116; $[\alpha]_{\mathrm{D}}^{23.7}$ : $-1.4(c 1.0, \mathrm{MeOH}) ; \delta_{\mathrm{H}}\left(500 \mathrm{MHz}, \mathrm{CDCl}_{3}\right): 7.74(\mathrm{~s}, 1 \mathrm{H}), 7.63-7.56$ $(\mathrm{m}, 2 \mathrm{H}), 7.56(\mathrm{~d}, J=7.7 \mathrm{~Hz}, 1 \mathrm{H}), 7.47(\mathrm{t}, J=7.7 \mathrm{~Hz}, 1 \mathrm{H}), 5.58(\mathrm{~d}, J$ $=15.5 \mathrm{~Hz}, 1 \mathrm{H}), 4.18(\mathrm{~d}, J=15.5 \mathrm{~Hz}, 1 \mathrm{H}), 4.15(\mathrm{dd}, J=6.5,3.6 \mathrm{~Hz}$, $1 \mathrm{H}), 3.35(\mathrm{~s}, 3 \mathrm{H}), 2.01-1.94(\mathrm{~m}, 1 \mathrm{H}), 1.87-1.78(\mathrm{~m}, 1 \mathrm{H}), 0.83(\mathrm{t}, J$ $=7.6 \mathrm{~Hz}, 3 \mathrm{H})$.

(R)-2-Chloro-7-ethyl-8-(3-methoxybenzyl)-5-methyl-7,8-dihydropteridin-6(5H)-one (22c). 22c was synthesized in $65 \%$ yield (colorless oil, $50 \mathrm{mg}, 0.14 \mathrm{mmol}$ ) according to the same procedure as 22a, from 21 (50 mg, $0.22 \mathrm{mmol}$ ) and 3-methoxybenzyl bromide (39 $\mu \mathrm{L}, 0.28 \mathrm{mmol}$ ). HRMS (ESI +ve): found $[\mathrm{M}]^{+}$347.1269, $\left[\mathrm{C}_{17} \mathrm{H}_{19} \mathrm{ClN}_{4} \mathrm{O}_{2}\right]^{+}$requires 347.1269; $[\alpha]_{\mathrm{D}}^{23.6}:-9.7(c$ 1.0, MeOH $)$; $\delta_{\mathrm{H}}\left(500 \mathrm{MHz}, \mathrm{CDCl}_{3}\right): 7.69(\mathrm{~s}, 1 \mathrm{H}), 7.28-7.24(\mathrm{~m}, 1 \mathrm{H}), 6.87-6.84$ $(\mathrm{m}, 3 \mathrm{H}), 5.63(\mathrm{~d}, J=15.1 \mathrm{~Hz}, 1 \mathrm{H}), 4.19(\mathrm{dd}, J=6.3,3.5 \mathrm{~Hz}, 1 \mathrm{H})$, $4.10(\mathrm{~d}, J=15.1 \mathrm{~Hz}, 1 \mathrm{H}), 3.79(\mathrm{~s}, 3 \mathrm{H}), 3.35(\mathrm{~s}, 3 \mathrm{H}), 2.00-1.93(\mathrm{~m}$, $1 \mathrm{H}), 1.93-1.81(\mathrm{~m}, 1 \mathrm{H}), 0.82(\mathrm{t}, J=7.6 \mathrm{~Hz}, 3 \mathrm{H})$.

(R)-2-Chloro-8-(2-bromobenzyl)-7-ethyl-5-methyl-7,8-dihydropteridin-6(5H)-one (22d). $22 \mathrm{~d}$ was synthesized in $62 \%$ yield (orange solid, $87 \mathrm{mg}, 0.22 \mathrm{mmol}$ ) according to the same procedure as $22 \mathrm{a}$, from $21(80 \mathrm{mg}, 0.35 \mathrm{mmol})$ and 1-(bromomethyl)-2-chloro-benzene $(111 \mathrm{mg}, 0.45 \mathrm{mmol})$. HRMS (ESI +ve): found $[\mathrm{M}]^{+} 397.0250$, $\left[\mathrm{C}_{16} \mathrm{H}_{16} \mathrm{BrClN}_{4} \mathrm{O}\right]^{+}$requires 397.0274; $[\alpha]_{\mathrm{D}}^{21.5}:-20.1(c 1.0, \mathrm{MeOH})$; $\delta_{\mathrm{H}}\left(500 \mathrm{MHz}, \mathrm{CDCl}_{3}\right): 7.72(\mathrm{~s}, 1 \mathrm{H}), 7.58(\mathrm{dd}, J=7.8,1.2 \mathrm{~Hz}, 1 \mathrm{H})$, $7.36(\mathrm{dd}, J=7.8,1.7 \mathrm{~Hz}, 1 \mathrm{H}), 7.30(\mathrm{~m}, 1 \mathrm{H}), 7.19(\mathrm{~m}, 1 \mathrm{H}), 5.63(\mathrm{~d}, J$ $=15.1 \mathrm{~Hz}, 1 \mathrm{H}), 4.33(\mathrm{~d}, J=15.1 \mathrm{~Hz}, 1 \mathrm{H}), 4.19(\mathrm{dd}, J=6.3,3.8 \mathrm{~Hz}$, $1 \mathrm{H}), 3.35(\mathrm{~s}, 3 \mathrm{H}), 1.98-1.86(\mathrm{~m}, 2 \mathrm{H}), 0.87(\mathrm{t}, J=7.6 \mathrm{~Hz}, 3 \mathrm{H})$.

(R)-2-Chloro-8-(4-bromobenzyl)-7-ethyl-5-methyl-7,8-dihydropteridin-6(5H)-one (22e). 22e was synthesized in $21 \%$ yield (white solid, $35 \mathrm{mg}, 0.09 \mathrm{mmol}$ ) according to the same procedure as 22a, from 21 (95 mg, $0.42 \mathrm{mmol}$ ) and 1-(bromomethyl)-4-chloro-benzene $(83 \mu \mathrm{L}, 0.50 \mathrm{mmol})$. HRMS (ESI +ve): found $[\mathrm{M}]^{+} 397.0249$, $\left[\mathrm{C}_{16} \mathrm{H}_{16} \mathrm{Cl}_{2} \mathrm{~N}_{4} \mathrm{O}\right]^{+}$requires 397.0247; $[\alpha]_{\mathrm{D}}^{22.3}:-47.1($ c 1.0, MeOH); $\delta_{\mathrm{H}}\left(500 \mathrm{MHz}, \mathrm{CDCl}_{3}\right): 7.71(\mathrm{~s}, 1 \mathrm{H}), 7.47(\mathrm{~d}, J=8.5 \mathrm{~Hz}, 2 \mathrm{H}), 7.18$ $(\mathrm{d}, J=8.5 \mathrm{~Hz}, 2 \mathrm{H}), 5.52(\mathrm{~d}, J=15.1 \mathrm{~Hz}, 1 \mathrm{H}), 4.14(\mathrm{dd}, J=6.3,3.5$ $\mathrm{Hz}, 1 \mathrm{H}), 4.10(\mathrm{~d}, J=15.1 \mathrm{~Hz}, 1 \mathrm{H}), 3.33(\mathrm{~s}, 3 \mathrm{H}), 1.98-1.90(\mathrm{~m}, 1 \mathrm{H})$, $1.86-1.77(\mathrm{~m}, 1 \mathrm{H}), 0.81(\mathrm{t}, J=7.6 \mathrm{~Hz}, 3 \mathrm{H})$. 
(R)-2-Chloro-7-ethyl-5-methyl-8-((4-methylthiazol-5-yl)methyl)7,8-dihydropteridin-6(5H)-one (22f). $22 \mathrm{f}$ was synthesized in $39 \%$ yield (white solid, $41 \mathrm{mg}, 0.12 \mathrm{mmol}$ ) according to the same procedure as $22 \mathrm{a}$, from $21(70 \mathrm{mg}, 0.31 \mathrm{mmol})$ and 5(chloromethyl)-4-methyl-1,3-thiazole ( $\mathrm{HCl}$ salt, $68 \mathrm{mg}, 0.37 \mathrm{mmol}$ ). HRMS (ESI +ve): found $[\mathrm{M}]^{+} 338.0838,\left[\mathrm{C}_{14} \mathrm{H}_{16} \mathrm{ClN}_{5} \mathrm{OS}\right]^{+}$requires $338.0837 ;[\alpha]_{\mathrm{D}}^{22.7}:-14.5(c 1.0, \mathrm{MeOH}) ; \delta_{\mathrm{H}}\left(500 \mathrm{MHz}, \mathrm{CDCl}_{3}\right): 8.68$ $(\mathrm{s}, 1 \mathrm{H}), 7.71(\mathrm{~s}, 1 \mathrm{H}), 5.46(\mathrm{~d}, J=15.5 \mathrm{~Hz}, 1 \mathrm{H}), 4.46(\mathrm{~d}, J=15.5 \mathrm{~Hz}$, $1 \mathrm{H}), 4.27(\mathrm{dd}, J=6.3,3.5 \mathrm{~Hz}, 1 \mathrm{H}), 3.33(\mathrm{~s}, 3 \mathrm{H}), 2.53(\mathrm{~s}, 3 \mathrm{H}), 2.04-$ $1.98(\mathrm{~m}, 1 \mathrm{H}), 1.88-1.70(\mathrm{~m}, 1 \mathrm{H}), 0.83(\mathrm{t}, J=7.4 \mathrm{~Hz}, 3 \mathrm{H})$.

(R)-8-(3-Chlorobenzyl)-2-((2-ethoxy-4-(1-methylpiperidin-4-yl)phenyl)amino)-7-ethyl-5-methyl-7,8-dihydropteridin-6(5H)-one (23a). 23a was synthesized in $13 \%$ yield (white solid, $8.0 \mathrm{mg}, 15$ $\mu \mathrm{mol}$ ) according to the same procedure as $16 \mathbf{h}$, from $22 \mathrm{a}(40 \mathrm{mg}, 110$ $\mu \mathrm{mol}$ ) and 10a $(25 \mathrm{mg}, 110 \mu \mathrm{mol})$. HRMS (ESI +ve): found $[\mathrm{M}]^{+}$ 549.2727, $\left[\mathrm{C}_{30} \mathrm{H}_{37} \mathrm{ClN}_{6} \mathrm{O}_{2}\right]^{+}$requires 549.2739; $[\alpha]_{\mathrm{D}}^{23.1}:+15.2(c$ 1.0, $\mathrm{MeOH}) ; \delta_{\mathrm{H}}\left(500 \mathrm{MHz}, \mathrm{CDCl}_{3}\right): 8.16(\mathrm{~d}, J=8.2 \mathrm{~Hz}, 1 \mathrm{H}), 7.71(\mathrm{~s}$, $1 \mathrm{H}), 7.46(\mathrm{~s}, 1 \mathrm{H}), 7.30-7.27(\mathrm{~m}, 2 \mathrm{H}), 7.23-7.20(\mathrm{~m}, 1 \mathrm{H}), 6.76-$ $6.70(\mathrm{~m}, 2 \mathrm{H}), 5.58(\mathrm{~d}, J=15.5 \mathrm{~Hz}, 1 \mathrm{H}), 4.18-4.09(\mathrm{~m}, 4 \mathrm{H}), 3.50(\mathrm{~d}$, $J=11.0 \mathrm{~Hz}, 2 \mathrm{H}), 3.36(\mathrm{~s}, 3 \mathrm{H}), 2.69(\mathrm{~s}, 3 \mathrm{H}), 2.69-2.59(\mathrm{~m}, 3 \mathrm{H}), 2.17$ $(\mathrm{q}, J=12.3 \mathrm{~Hz}, 2 \mathrm{H}), 2.00-1.91(\mathrm{~m}, 3 \mathrm{H}), 1.88-1.80(\mathrm{~m}, 1 \mathrm{H}), 1.47(\mathrm{t}$, $J=7.6 \mathrm{~Hz}, 3 \mathrm{H}), 0.87(\mathrm{t}, J=7.0 \mathrm{~Hz}, 3 \mathrm{H})$.

(R)-3-((2-((2-Ethoxy-4-(1-methylpiperidin-4-yl)phenyl)amino)-7ethyl-5-methyl-6-oxo-6,7-dihydropteridin-8(5H)-yl)methyl)benzonitrile (23b). 23b was synthesized in 10\% yield (white solid, 6.6 $\mathrm{mg}, 12 \mu \mathrm{mol}$ ) according to the same procedure as $16 \mathrm{~h}$, from $22 \mathrm{~b}$ (40 $\mathrm{mg}, 120 \mu \mathrm{mol})$ and $10 \mathrm{a}(26 \mathrm{mg}, 110 \mu \mathrm{mol})$. HRMS (ESI +ve): found $[\mathrm{M}]^{+}$540.3071, $\left[\mathrm{C}_{31} \mathrm{H}_{37} \mathrm{~N}_{7} \mathrm{O}_{2}\right]^{+}$requires 540.3081; $[\alpha]_{\mathrm{D}}^{24.0}:-2.1(c$ $1.0, \mathrm{MeOH}) ; \delta_{\mathrm{H}}\left(500 \mathrm{MHz}, \mathrm{CDCl}_{3}\right): 8.08(\mathrm{~d}, J=8.2 \mathrm{~Hz}, 1 \mathrm{H}), 7.73$ $(\mathrm{s}, 1 \mathrm{H}), 7.62-7.55(\mathrm{~m}, 3 \mathrm{H}), 7.47(\mathrm{t}, J=7.9 \mathrm{~Hz}, 1 \mathrm{H}), 7.41(\mathrm{~s}, 1 \mathrm{H})$, 6.73-6.69 (m, 2H), $5.55(\mathrm{~d}, J=15.5 \mathrm{~Hz}, 1 \mathrm{H}), 4.23(\mathrm{~d}, J=15.5 \mathrm{~Hz}$, $1 \mathrm{H}), 4.14-4.07(\mathrm{~m}, 3 \mathrm{H}), 3.44(\mathrm{~d}, J=11.7 \mathrm{~Hz}, 2 \mathrm{H}), 3.37(\mathrm{~s}, 3 \mathrm{H})$, $2.64(\mathrm{~s}, 3 \mathrm{H}), 2.63-2.52(\mathrm{~m}, 3 \mathrm{H}), 2.12(\mathrm{q}, J=13.2 \mathrm{~Hz}, 2 \mathrm{H}), 2.00-$ $1.91(\mathrm{~m}, 3 \mathrm{H}), 1.86-1.77(\mathrm{~m}, 1 \mathrm{H}), 1.46(\mathrm{t}, J=6.9 \mathrm{~Hz}, 3 \mathrm{H}), 0.87(\mathrm{t}, J$ $=7.4 \mathrm{~Hz}, 3 \mathrm{H})$.

(R)-8-(3-Methoxybenzyl)-2-((2-ethoxy-4-(1-methylpiperidin-4yl)phenyl)amino)-7-ethyl-5-methyl-7,8-dihydropteridin-6(5H)-one (23c). 23c was synthesized in $32 \%$ yield (yellow solid, $20 \mathrm{mg}, 37$ $\mu \mathrm{mol}$ ) according to the same procedure as $\mathbf{1 6 h}$, from $22 \mathrm{c}(40 \mathrm{mg}, 120$ $\mu \mathrm{mol})$ and 10a $(26 \mathrm{mg}, 110 \mu \mathrm{mol})$. HRMS (ESI +ve): found $[\mathrm{M}]^{+}$ 545.3221, $\left[\mathrm{C}_{31} \mathrm{H}_{40} \mathrm{~N}_{6} \mathrm{O}_{3}\right]^{+}$requires 545.3235; $[\alpha]_{\mathrm{D}}^{24.0}:+13.2($ c 1.0, $\mathrm{MeOH}) ; \delta_{\mathrm{H}}\left(500 \mathrm{MHz}, \mathrm{CDCl}_{3}\right): 8.19(\mathrm{~d}, J=8.8 \mathrm{~Hz}, 1 \mathrm{H}), 7.71(\mathrm{~s}$, $1 \mathrm{H}), 7.67(1 \mathrm{H}), 7.29-7.26(\mathrm{~m}, 1 \mathrm{H}), 6.91(\mathrm{~d}, J=7.6 \mathrm{~Hz}, 1 \mathrm{H}), 6.88-$ $6.84(\mathrm{~m}, 2 \mathrm{H}), 6.75-6.72(\mathrm{~m}, 2 \mathrm{H}), 5.61(\mathrm{~d}, J=15.1 \mathrm{~Hz}, 1 \mathrm{H}), 4.18-$ $4.09(\mathrm{~m}, 4 \mathrm{H}), 3.77(\mathrm{~s}, 3 \mathrm{H}), 3.61(\mathrm{~d}, J=8.8 \mathrm{~Hz}, 2 \mathrm{H}), 3.34(\mathrm{~s}, 3 \mathrm{H})$, $2.80-2.69(\mathrm{~m}, 2 \mathrm{H}), 2.75(\mathrm{~s}, 3 \mathrm{H}), 2.67-2.60(\mathrm{~m}, 1 \mathrm{H}), 2.19(\mathrm{q}, J=$ $12.4 \mathrm{~Hz}, 2 \mathrm{~h}), 2.02-1.90(\mathrm{~m}, 3 \mathrm{H}), 1.89-1.80(\mathrm{~m}, 1 \mathrm{H}), 1.48(\mathrm{t}, J=6.9$ $\mathrm{Hz}, 3 \mathrm{H}), 0.85(\mathrm{t}, J=7.6 \mathrm{~Hz}, 3 \mathrm{H})$.

(R)-8-(2-Bromobenzyl)-2-((2-ethoxy-4-(1-methylpiperidin-4-yl)phenyl)amino)-7-ethyl-5-methyl-7,8-dihydropteridin-6(5H)-one (23d). 23d was synthesized in $13 \%$ yield (yellow solid, $7.1 \mathrm{mg}, 12$ $\mu \mathrm{mol}$ ) according to the same procedure as $\mathbf{1 6 h}$, from $22 \mathrm{~d}(36 \mathrm{mg}, 91$ $\mu \mathrm{mol})$ and $10 \mathrm{a}(20 \mathrm{mg}, 86 \mu \mathrm{mol})$. HRMS $(\mathrm{ESI}+\mathrm{ve})$ : found $[\mathrm{M}]^{+}$ 593.2210, $\left[\mathrm{C}_{30} \mathrm{H}_{37} \mathrm{BrN}_{6} \mathrm{O}_{2}\right]^{+}$requires 593.2231; $[\alpha]_{\mathrm{D}}^{22.0}:-19.39(c 1.0$, $\mathrm{MeOH}) ; \delta_{\mathrm{H}}\left(500 \mathrm{MHz}, \mathrm{CDCl}_{3}\right): 8.06(\mathrm{~d}, J=8.8 \mathrm{~Hz}, 1 \mathrm{H}), 7.70(\mathrm{~s}$, $1 \mathrm{H}), 7.57(\mathrm{~d}, J=7.6 \mathrm{~Hz}, 1 \mathrm{H}), 7.52(\mathrm{~s}, 1 \mathrm{H}), 7.29-7.26(\mathrm{~m}, 2 \mathrm{H})$, $7.19-7.16(\mathrm{~m}, 1 \mathrm{H}), 6.72-6.70(\mathrm{~m}, 2 \mathrm{H}), 5.41(\mathrm{~d}, J=16.1 \mathrm{~Hz}, 1 \mathrm{H})$, $4.30(\mathrm{~d}, J=16.1 \mathrm{~Hz}, 1 \mathrm{H}), 4.15(\mathrm{dd}, J=6.6,3.8 \mathrm{~Hz}, 1 \mathrm{H}), 4.10(\mathrm{q}, J=$ $6.9 \mathrm{~Hz}, 2 \mathrm{H}), 3.54(\mathrm{~d}, J=10.7 \mathrm{~Hz}, 2 \mathrm{H}), 3.37(\mathrm{~s}, 3 \mathrm{H}), 2.74-2.60(\mathrm{~m}$, $6 \mathrm{H}), 2.17(\mathrm{~m}, 2 \mathrm{H}), 2.02-1.86(\mathrm{~m}, 4 \mathrm{H}), 1.47(\mathrm{t}, J=6.9 \mathrm{~Hz}, 3 \mathrm{H})$.

(R)-8-(4-Bromobenzyl)-2-((2-ethoxy-4-(1-methylpiperidin-4-yl)phenyl)amino)-7-ethyl-5-methyl-7,8-dihydropteridin-6(5H)-one (23e). 23e was synthesized in 6\% yield (yellow solid, $3.4 \mathrm{mg}, 5.7$ $\mu \mathrm{mol}$ ) according to the same procedure as $16 \mathrm{~h}$, from $22 \mathrm{e}(35 \mathrm{mg}, 89$ $\mu \mathrm{mol})$ and $10 \mathrm{~b}(20 \mathrm{mg}, 84 \mu \mathrm{mol})$. HRMS (ESI +ve): found $[\mathrm{M}]^{+}$ 593.2242, $\left[\mathrm{C}_{30} \mathrm{H}_{37} \mathrm{BrN}_{6} \mathrm{O}_{2}\right]^{+}$requires 593.2234; $[\alpha]_{\mathrm{D}}^{23.4}:+6.2(c 1.0$, $\mathrm{MeOH}) ; \delta_{\mathrm{H}}\left(500 \mathrm{MHz}, \mathrm{CDCl}_{3}\right): 8.16(\mathrm{~d}, J=7.9 \mathrm{~Hz}, 1 \mathrm{H}), 7.69(\mathrm{~s}$, $1 \mathrm{H}), 7.59(\mathrm{~s}, 1 \mathrm{H}), 7.47(\mathrm{~d}, J=8.2 \mathrm{~Hz}, 2 \mathrm{H}), 7.20(\mathrm{~d}, J=8.2 \mathrm{~Hz}, 2 \mathrm{H})$, 6.74-6.69 (m, 2H), $5.51(\mathrm{~d}, J=15.5 \mathrm{~Hz}, 1 \mathrm{H}), 4.19-4.09(\mathrm{~m}, 4 \mathrm{H})$, $3.58(\mathrm{~d}, J=9.1 \mathrm{~Hz}, 2 \mathrm{H}), 3.34(\mathrm{~s}, 3 \mathrm{H}), 2.74(\mathrm{~s}, 3 \mathrm{H}), 2.75-2.59(\mathrm{~m}$,
$3 \mathrm{H}), 2.19(\mathrm{~m}, 2 \mathrm{H}), 2.02-1.90(\mathrm{~m}, 3 \mathrm{H}), 1.85-1.76(\mathrm{~m}, 1 \mathrm{H}), 1.47(\mathrm{t}, J$ $=6.9 \mathrm{~Hz}, 3 \mathrm{H})$.

(R)-2-((2-Ethoxy-4-(1-methylpiperidin-4-yl)phenyl)amino)-7ethyl-5-methyl-8-((4-methylthiazol-5-yl)methyl)-7,8-dihydropteridin-6(5H)-one (23f). 23f was synthesized in $31 \%$ yield (yellow solid, $17 \mathrm{mg}, 32 \mu \mathrm{mol}$ ) according to the same procedure as $16 \mathbf{h}$, from $22 \mathrm{f}$ (35 mg, $100 \mu \mathrm{mol})$ and 10a $(23 \mathrm{mg}, 100 \mu \mathrm{mol})$. HRMS (ESI +ve): found $[\mathrm{M}]^{+}$536.2787, $\left[\mathrm{C}_{28} \mathrm{H}_{37} \mathrm{~N}_{7} \mathrm{O}_{2} \mathrm{~S}\right]^{+}$requires 536.2802; $[\alpha]_{\mathrm{D}}^{22.8}$ : $-8.3(c 1.0, \mathrm{MeOH}) ; \delta_{\mathrm{H}}\left(500 \mathrm{MHz}, \mathrm{CDCl}_{3}\right): 8.65(\mathrm{~s}, 1 \mathrm{H}), 8.24(\mathrm{~d}, J$ $=8.3 \mathrm{~Hz}, 1 \mathrm{H}), 7.69(\mathrm{~s}, 1 \mathrm{H}), 7.64(\mathrm{~s}, 1 \mathrm{H}), 6.77(\mathrm{dd}, J=8.3,1.8 \mathrm{~Hz}$, $1 \mathrm{H}), 6.74(\mathrm{~d}, J=1.8 \mathrm{~Hz}, 1 \mathrm{H}), 5.47(\mathrm{~d}, J=15.8 \mathrm{~Hz}, 1 \mathrm{H}), 4.48(\mathrm{~d}, J=$ $15.8 \mathrm{~Hz}, 1 \mathrm{H}), 4.17(\mathrm{~d}, J=6.5,3.6 \mathrm{~Hz}, 1 \mathrm{H}), 4.13(\mathrm{q}, J=7.0 \mathrm{~Hz}, 2 \mathrm{H})$, $3.61(\mathrm{~d}, J=10.4 \mathrm{~Hz}, 2 \mathrm{H}), 3.32(\mathrm{~s}, 3 \mathrm{H}), 2.75(\mathrm{~s}, 3 \mathrm{H}), 2.75-2.70(\mathrm{~m}$, $2 \mathrm{H}), 2.66-2.63(\mathrm{~m}, 1 \mathrm{H}), 2.52(\mathrm{~s}, 3 \mathrm{H}), 2.26-2.15(\mathrm{~m}, 2 \mathrm{H}), 2.03-$ $1.94(\mathrm{~m}, 3 \mathrm{H}), 1.86-1.76(\mathrm{~m}, 1 \mathrm{H}), 1.49(\mathrm{t}, J=7.0 \mathrm{~Hz}, 3 \mathrm{H}), 0.84(\mathrm{t}, J$ $=7.6 \mathrm{~Hz}, 3 \mathrm{H})$.

ALK $^{\text {F1174L }}$ Kinase Assay. ALK ${ }^{\mathrm{F} 1174 \mathrm{~L}}$ activity was measured in a LanthaScreen Eu kinase binding assay. The assay was performed in 384-well plates containing $\mathrm{ALK}^{\mathrm{F} 1174 \mathrm{~L}}$ enzyme (5 nM, Carna Biosciences), Kinase Tracer 236 ( $30 \mathrm{nM}$, Thermo Fisher Scientific), LanthaScreen Eu-anti-GST antibody ( $2 \mathrm{nM}$, Thermo Fisher Scientific), either $1 \%(\mathrm{v} / \mathrm{v})$ dimethyl sulfoxide (DMSO) or the test compound (in the range from $0.5 \mathrm{nM}$ to $100 \mu \mathrm{M}$ in $1 \%$ (v/v) DMSO), and assay buffer (50 mM N-(2-hydroxyethyl)piperazine- $N^{\prime}$ ethanesulfonic acid (HEPES) pH 7.5; $10 \mathrm{mM} \mathrm{MgCl}_{2} ; 1 \mathrm{mM}$ ethylene glycol-bis ( $\beta$-aminoethyl ether)- $N, N, N^{\prime}, N^{\prime}$-tetraacetic acid and $0.01 \%$ (w/v) Brij-35; $1 \mathrm{mM}$ dithiothreitol). The reaction was incubated for $60 \mathrm{~min}$ at room temperature. The plate was read on an EnVision multilabel plate reader (PerkinElmer, U.K.) calculating an emission ratio between the acceptor/tracer emission $(665 \mathrm{nM})$ and the antibody/donor emission $(615 \mathrm{nM}) . \mathrm{IC}_{50}$ values were determined using a nonlinear regression fit of the $\log$ (inhibitor concentration) versus emission ratio with a variable slope equation.

Bromodomain Thermal Shift. BRD4 thermal shift was measured in a differential scanning fluorimetry (DSF) assay. The assay was performed on a Stratagene Mx3005P system quantitative polymerase chain reaction (qPCR). The assay was performed in 96well plates with $20 \mu \mathrm{L}$ of protein at $2 \mu \mathrm{M}$ in DSF-assay buffer $(10 \mathrm{mM}$ HEPES $\mathrm{pH} 7.5,500 \mathrm{mM} \mathrm{NaCl}$ ) to which $4 \mu \mathrm{L}$ of Sypro orange dye and $0.4 \mu \mathrm{L}$ of $10 \mu \mathrm{M}$ compound in DMSO was added. The plate was sealed and centrifuged ( $1 \mathrm{~min}, 1000 \mathrm{rpm})$, and the qPCR machine was used to detect SYPRO fluorescence while increasing the temperature from 25 to $95{ }^{\circ} \mathrm{C}$ in 71 cycles. The sigmoidal part of the fluorescence signal was fitted using the Boltzmann equation, the points of change were defined, and the thermal shift was calculated by subtracting the protein/DMSO $T_{\mathrm{m}}$ shift from the protein/compound $T_{\mathrm{m}}$ shift.

BRD4 Isothermal Calorimetry. BRD4 activity was measured by isothermal calorimetry. The sample cell, sample syringe, and injection syringe were all equilibrated with gel filtration buffer (10 mM HEPES, $150 \mathrm{mM} \mathrm{NaCl}, 0.5 \mathrm{mM}$ tris(2-carboxyethyl)phosphine (TCEP), 5\% glycerol). The sample syringe was filled with compound solution (30-40 $\mu \mathrm{M}$ in gel filtration buffer), and the injection syringe was filled with protein solution ( $300 \mu \mathrm{M}$ in gel filtration buffer). After equilibration of the machine, protein was injected over 21-30 injections, $8 \mu \mathrm{L}$ each time. For the analysis of the data, the baseline and integration points were defined to determine binding heats. Data was fitted to the Boltzmann equation to determine thermodynamic parameters.

PLK-1 Kinase Assay. All PLK-1 $\mathrm{IC}_{50} \mathrm{~s}$ and percentage inhibitions at 10 and $100 \mathrm{nM}$ were tested by Thermo Fisher Scientific in a ŹLYTE activity assay using their SelectScreen biochemical kinase profiling service.

Kinase Selectivity Profiling. Compound $\mathrm{X}$ was assayed at $1 \mu \mathrm{M}$ in the DiscoveRx KINOMEscan (scanEDGE) assay platform. The results for single-concentration binding interactions are reported as "\% Ctrl" (DMSO = 100\%Ctrl), where lower numbers indicate stronger hits.

Immunoassay and Immunoblotting. The human neuroblastoma Kelly cell line was maintained in RPMI with $10 \%$ fetal calf 
serum. For dose-response experiments, cells were seeded into $10 \mathrm{~cm}$ dishes and, following attachment, treated with the indicated compound concentration in fresh media. After $3 \mathrm{~h}$, the plates were transferred onto ice, the media were taken off, and the cells were washed once with ice-cold phosphate-buffered saline (PBS), before adding 5\% CHAPS lysis buffer. After $20 \mathrm{~min}$ in lysis buffer, cells were scraped, transferred into Eppendorfs, and spun at $4{ }^{\circ} \mathrm{C}$ for $12 \mathrm{~min}$ at $12000 \mathrm{rpm}$. The supernatant was transferred to a fresh tube, and the protein content was quantified using the Direct Detect system (Millipore). For ALK immunoassay analysis, $15 \mu \mathrm{g}$ of protein per well was added in duplicate for each sample to measure either total or pY1586 ALK, and for immunoblotting, $5 \mu \mathrm{g}$ of denatured lysates were loaded into $4-12 \%$ Bis/Tris gels, both according to previously published methods. ${ }^{37}$

Crystallization, Data collection, and Processing. Purified protein in $25 \mathrm{mM}$ HEPES $\mathrm{pH} 7.5,300 \mathrm{mM} \mathrm{NaCl}, 0.5 \mathrm{mM}$ TCEP, $5 \%$ glycerol was cocrystallized with compounds in 1:3 molar ratio at 293 $\mathrm{K}$ using sitting drop vapor diffusion. Reservoir solutions contained $25 \%$ poly(ethylene glycol)3350, $0.2 \mathrm{M}$ ammonium sulfate, $0.1 \mathrm{M}$ BisTris $\mathrm{pH} 6.5$ or $30 \%$ pentaerythritol ethoxylate $15 / 4,0.05$ ammonium sulfate, $0.1 \mathrm{M}$ Bis-Tris $\mathrm{pH} 6.5$ respectively.

Diffraction data were collected at the SLS X06S overlaid with X-ray $\mathrm{A}$ and BESSY II 14.2 and processed using either XDS (PMID 20124692) or iMOSFLM (PMID 28569763). The data was scaled using aimless from the CCP4 suite (PMID 29533233) and phased with PHASER (PMID 28573584) using PDB ID 4OGI (PMID 24584101) as initial model. Manual model rebuilding alternated with structure refinement was performed in COOT (PMID 28291755) and REFMAC (PMID 15572771), respectively. Geometry of the final models was verified using MolProbity (PMID 29067766). Data collection and refinement statistics are summarized in Supp. Table 3.

NanoBRET Target Engagement Assay. The NanoBRET target engagement assay in principle was performed as described previously. ${ }^{38,39}$ The full-length ALK and BRDBD1 plasmid containing C-terminal placements of NanoLuc were obtained by the manufacturer (Promega). To lower intracellular expression levels of the reporter fusion, the NanoLuc/kinase fusion construct was diluted into carrier DNA (pGEM3ZF-, Promega) at a mass ratio of 1:10 (mass/mass), prior to forming FuGENE HD complexes according to the manufacturer's instructions (Promega). DNA-FuGENE complexes were formed at a ratio of $1: 3(\mu \mathrm{g}$ DNA $/ \mu \mathrm{L}$ FuGENE). One part of the transfection complexes was then mixed with 20 parts $(\mathrm{v} / \mathrm{v})$ of HEK293T cells suspended at a density of $2 \times 10^{5} / \mathrm{mL}$ in Dulbecco's modified Eagle's medium (Gibco) $+10 \%$ fetal bovine serum (GE Healthcare), seeded into T75 flasks, and allowed to express for $20 \mathrm{~h}$. For target engagement, both serially diluted test compound and NanoBRET Kinase Tracer K5 (ALK) and BRDTracer (BRD4BD1) (Promega) at a final concentration of 2 and 0.5 $\mu \mathrm{M}$, respectively, were pipetted into white 96-well plates (Corning 3600). The corresponding ALK or BRD4BD1-transfected cells were added and reseeded at a density of $2 \times 10^{5} / \mathrm{mL}$ after trypsinization and resuspending in Opti-MEM without phenol red (Life Technologies). The system was allowed to equilibrate for $2 \mathrm{~h}$ at 37 ${ }^{\circ} \mathrm{C} / 5 \% \mathrm{CO}_{2}$ prior to BRET measurements. To measure BRET, NanoBRET NanoGlo substrate + extracellular NanoLuc inhibitor (Promega) was added as per the manufacturer's protocol, and filtered luminescence was measured on a CLARIOstar plate reader (BMG Labtech) equipped with a $450 \mathrm{~nm}$ band-pass filter (donor) and a 610 $\mathrm{nm}$ low-pass filter (acceptor). Competitive displacement data were then graphed using GraphPad Prism 7 software using a fourparameter curve fit with the following equation: $Y=$ bottom + (top bottom $) /\left(1+10^{\left(\left(\log I \mathrm{IC}_{50}-X\right) \times \text { Hillslope }\right)}\right)$.

Western Blot Analysis. Protein extracts of cells were prepared by lysis in radioimmunoprecipitation assay buffer (Sigma) supplemented with protease inhibitors (complete protease inhibitor cocktail, Roche). Protein extracts $(25 \mu \mathrm{g})$ were separated by sodium dodecyl sulfate-polyacrylamide gel electrophoresis and transferred onto poly(vinylidene difluoride) membranes using the Trans-Blot Turbo transfer system (BioRad). After blocking with $5 \%$ bovine serum albumin in PBS with $0.1 \%$ Tween-20 for $30 \mathrm{~min}$, the membrane was incubated with primary antibodies for $1 \mathrm{~h}$ at room temperature. Horseradish peroxidase-linked secondary antibodies were incubated $30 \mathrm{~min}$ at room temperature followed by enhanced chemiluminescence (ECL) detection (ECL Western blot substrate, Pierce).

Antibodies. Primary antibodies were obtained from the following sources: PLK-1 (05-844) and phosphohistone H3 (Ser10) (05806) from Millipore; pPlk1-T210 (5472) from Cell Signaling; pPlk1-S137 (21738) from Abcam; and cyclin B1 (GNS1) and $\beta$-actin (A2228) from Sigma-Aldrich served as loading control.

Docking. Docking studies were performed using Glide, Schrödinger, LLC, New York, NY, 2018. Preparation of ALK using PDB codes 2XB7 was performed using Schrödinger Suite 2018-3 Protein Preparation Wizard; Epik, Schrödinger, LLC, New York, NY, 2018, and preparation of ligands was performed using LigPrep, Schrödinger, LLC, New York, NY, 2018.

\section{ASSOCIATED CONTENT}

\section{Supporting Information}

The Supporting Information is available free of charge on the ACS Publications website at DOI: 10.1021/acs.jmedchem.8b01947.

\section{Molecular formula strings (CSV)}

Tables with standard deviations for all compounds; data collection and refinement statistics for BRD4-ligand complexes with 16i and 16k; kinase and bromodomain selectivity profiling of $\mathbf{1 6} \mathbf{k}$; chiral shift NMR and HPLC experiments; and cell cycle analysis of BI-2536 and 16k (PDF)

\section{Accession Codes}

The PDB codes for $\mathbf{1 6} \mathbf{i}$ and $\mathbf{1 6} \mathbf{k}$ bound to BRD4(1) are 6Q3Y and $6 \mathrm{Q} 3 \mathrm{Z}$, respectively.

\section{AUTHOR INFORMATION}

\section{Corresponding Authors}

*E-mail: Benjamin.Bellenie@icr.ac.uk. Phone: +44 (0) 2087224602 (B.B.).

*E-mail: Swen.Hoelder@icr.ac.uk. Phone: +44 (0) 2087224353 (S.H.).

ORCID

Stefan Knapp: 0000-0001-5995-6494

Swen Hoelder: 0000-0001-8636-1488

Notes

The authors declare no competing financial interest.

\section{ACKNOWLEDGMENTS}

E.W. was funded by the Sir John Fisher Foundation. We also acknowledge funding from Cancer Research UK (Grant Number C309/A11566). E.T. and L.C. acknowledge funding from Cancer Research UK Programme Grant, C18339, and ICR HEFCE. S.K. and D.H. are grateful for support by the SGC, a registered charity (number 1097737) that receives funds from AbbVie, Bayer Pharma AG, Boehringer Ingelheim, Canada Foundation for Innovation, Eshelman Institute for Innovation, Genome Canada, Innovative Medicines Initiative (EU/EFPIA) (ULTRA-DD grant no. 115766), Janssen, Merck KGaA Darmstadt Germany, MSD, Novartis Pharma AG, Ontario Ministry of Economic Development and Innovation, Pfizer, São Paulo Research Foundation-FAPESP, Takeda, and Wellcome (106169/ZZ14/Z), and the DFG-funded center of excellence (CEF) at Frankfurt University. S.K. is grateful for support by the German cancer network DKTK. We thank Dr. Amin Mirza, Dr. Maggie Liu, Meirion Richards, and Katia Grira for their help with LC, NMR, and mass spectrometry. 
We also thank Drs. Jack Cheung and Angela Hayes for collection of solubility and permeability data, respectively and to Yvette Newbatt for help with developing the kinase binding assay.

\section{ABBREVIATIONS}

ALK, anaplastic lymphoma kinase; BET, bromo- and extraterminal domain; BRD4, bromodomain 4; DMB, dimethoxybenzyl; INSR, insulin receptor; MSD, meso-scale discovery; MYCN, n-myc proto-oncogene protein; PLK, polo-like kinase

\section{REFERENCES}

(1) Park, J. R.; Eggert, A.; Caron, H. Neuroblastoma: Biology, Prognosis, and Treatment. Pediatr. Clin. North Am. 2008, 55, 97-120. (2) Berry, T.; Luther, W.; Bhatnagar, N.; Jamin, Y.; Poon, E.; Sanda, T.; Pei, D.; Sharma, B.; Vetharoy, W. R.; Hallsworth, A.; Ahmad, Z.; Barker, K.; Moreau, L.; Webber, H.; Wang, W.; Liu, Q.; Perez-Atayde, A.; Rodig, S.; Cheung, N.-K.; Raynaud, F.; Hallberg, B.; Robinson, S. P.; Gray, N. S.; Pearson, A. D. J.; Eccles, S. A.; Chesler, L.; George, R. E. The ALKF1174L Mutation Potentiates the Oncogenic Activity of MYCN in Neuroblastoma. Cancer Cell 2012, 22, 117-130.

(3) Bresler, S. C.; Wood, A. C.; Haglund, E. A.; Courtright, J.; Belcastro, L. T.; Plegaria, J. S.; Cole, K.; Toporovskaya, Y.; Zhao, H.; Carpenter, E. L.; Christensen, J. G.; Maris, J. M.; Lemmon, M. A.; Mossé, Y. P. Differential Inhibitor Sensitivity of Anaplastic Lymphoma Kinase Variants Found in Neuroblastoma. Sci. Transl. Med. 2011, 3, No. 108ra114.

(4) Study Of Lorlatinib (PF-06463922) - NCT03107988.

(5) Puissant, A.; Frumm, S. M.; Alexe, G.; Bassil, C. F.; Qi, J.; Chanthery, Y. H.; Nekritz, E. A.; Zeid, R.; Gustafson, W. C.; Greninger, P.; Garnett, M. J.; McDermott, U.; Benes, C. H.; Kung, A. L.; Weiss, W. A.; Bradner, J. E.; Stegmaier, K. Targeting MYCN in Neuroblastoma by BET Bromodomain Inhibition. Cancer Discovery 2013, 3, 308-323.

(6) Delmore, J. E.; Issa, G. C.; Lemieux, M. E.; Rahl, P. B.; Shi, J.; Jacobs, H. M.; Kastritis, E.; Gilpatrick, T.; Paranal, R. M.; Qi, J.; Chesi, M.; Schinzel, A. C.; McKeown, M. R.; Heffernan, T. P.; Vakoc, C. R.; Bergsagel, P. L.; Ghobrial, I. M.; Richardson, P. G.; Young, R. A.; Hahn, W. C.; Anderson, K. C.; Kung, A. L.; Bradner, J. E.; Mitsiades, C. S. BET Bromodomain Inhibition as a Therapeutic Strategy to Target c-Myc. Cell 2011, 146, 904-917.

(7) Mertz, J. A.; Conery, A. R.; Bryant, B. M.; Sandy, P.; Balasubramanian, S.; Mele, D. A.; Bergeron, L.; Sims, R. J. Targeting MYC Dependence in Cancer by Inhibiting BET Bromodomains. Proc. Natl. Acad. Sci. 2011, 108, 16669-16674.

(8) Filippakopoulos, P.; Knapp, S. Targeting Bromodomains: Epigenetic Readers of Lysine Acetylation. Nat. Rev. Drug Discovery 2014, 13, 337-356.

(9) Barone, G.; Anderson, J.; Pearson, A. D. J.; Petrie, K.; Chesler, L. New Strategies in Neuroblastoma: Therapeutic Targeting of MYCN and ALK. Clin. Cancer Res. 2013, 19, 5814-5821.

(10) Peters, J.-U. Polypharmacology - Foe or Friend? J. Med. Chem. 2013, 56, 8955-8971.

(11) Amirouchene-Angelozzi, N.; Swanton, C.; Bardelli, A. Tumor Evolution as a Therapeutic Target. Cancer Discovery 2017, 7, 805817.

(12) Patyar, S.; Prakash, A.; Medhi, B. Dual Inhibition: a Novel Promising Pharmacological Approach for Different Disease Conditions. J. Pharm. Pharmacol. 2011, 63, 459-471.

(13) Humphrey, R. W.; Brockway-Lunardi, L. M.; Bonk, D. T.; Dohoney, K. M.; Doroshow, J. H.; Meech, S. J.; Ratain, M. J.; Topalian, S. L.; Pardoll, D. M. Opportunities and Challenges in the Development of Experimental Drug Combinations for Cancer. JNCI, J. Natl. Cancer Inst. 2011, 103, 1222-1226.

(14) Ciceri, P.; Muller, S.; O’Mahony, A.; Fedorov, O.; Filippakopoulos, P.; Hunt, J. P.; Lasater, E. A.; Pallares, G.; Picaud, S.; Wells, C.; Martin, S.; Wodicka, L. M.; Shah, N. P.; Treiber, D. K.;
Knapp, S. Dual Kinase-Bromodomain Inhibitors for Rationally Designed Polypharmacology. Nat. Chem. Biol. 2014, 10, 305-312.

(15) Ember, S. W. J.; Zhu, J.-Y.; Olesen, S. H.; Martin, M. P.; Becker, A.; Berndt, N.; Georg, G. I.; Schönbrunn, E. Acetyl-lysine Binding Site of Bromodomain-Containing Protein 4 (BRD4) Interacts with Diverse Kinase Inhibitors. ACS Chem. Biol. 2014, 9, 1160-1171.

(16) Dittmann, A.; Werner, T.; Chung, C.-W.; Savitski, M. M.; Fälth Savitski, M.; Grandi, P.; Hopf, C.; Lindon, M.; Neubauer, G.; Prinjha, R. K.; Bantscheff, M.; Drewes, G. The Commonly Used PI3-Kinase Probe LY294002 Is an Inhibitor of BET Bromodomains. ACS Chem. Biol. 2014, 9, 495-502.

(17) Andrews, F. H.; Singh, A. R.; Joshi, S.; Smith, C. A.; Morales, G. A.; Garlich, J. R.; Durden, D. L.; Kutateladze, T. G. Dual-activity PI3K-BRD4 Inhibitor for the Orthogonal Inhibition of MYC to Block Tumor Growth and Metastasis. Proc. Natl. Acad. Sci. 2017, 114, E1072-E1080.

(18) Gohda, J.; Suzuki, K.; Liu, K.; Xie, X.; Takeuchi, H.; Inoue, J.-i.; Kawaguchi, Y.; Ishida, T. BI-2536 and BI-6727, Dual Polo-like Kinase/Bromodomain Inhibitors, Effectively Reactivate Latent HIV-1. Sci. Rep. 2018, 8, No. 3521.

(19) Ember, S. W.; Lambert, Q. T.; Berndt, N.; Gunawan, S.; Ayaz, M.; Tauro, M.; Zhu, J.-Y.; Cranfill, P. J.; Greninger, P.; Lynch, C. C.; Benes, C. H.; Lawrence, H. R.; Reuther, G. W.; Lawrence, N. J.; Schönbrunn, E. Potent Dual BET Bromodomain-Kinase Inhibitors as Value-Added Multitargeted Chemical Probes and Cancer Therapeutics. Mol. Cancer Ther. 2017, 16, 1054-1067.

(20) Steegmaier, M.; Hoffmann, M.; Baum, A.; Lénárt, P.; Petronczki, M.; Krššák, M.; Gürtler, U.; Garin-Chesa, P.; Lieb, S.; Quant, J.; Grauert, M.; Adolf, G. R.; Kraut, N.; Peters, J.-M.; Rettig, W. J. BI 2536, a Potent and Selective Inhibitor of Polo-like Kinase 1, Inhibits Tumor Growth In Vivo. Curr. Biol. 2007, 17, 316-322.

(21) Kothe, M.; Kohls, D.; Low, S.; Coli, R.; Rennie, G. R.; Feru, F.; Kuhn, C.; Ding, Y.-H. Research Article: Selectivity-determining Residues in Plk1. Chem. Biol. Drug Des. 2007, 70, 540-546.

(22) Galkin, A. V.; Melnick, J. S.; Kim, S.; Hood, T. L.; Li, N.; Li, L.; Xia, G.; Steensma, R.; Chopiuk, G.; Jiang, J.; Wan, Y.; Ding, P.; Liu, Y.; Sun, F.; Schultz, P. G.; Gray, N. S.; Warmuth, M. Identification of NVP-TAE684, a Potent, Selective, and Efficacious Inhibitor of NPMALK. Proc. Natl. Acad. Sci. 2007, 104, 270-275.

(23) Davis, M. I.; Hunt, J. P.; Herrgard, S.; Ciceri, P.; Wodicka, L. M.; Pallares, G.; Hocker, M.; Treiber, D. K.; Zarrinkar, P. P. Comprehensive Analysis of Kinase Inhibitor Selectivity. Nat. Biotechnol. 2011, 29, 1046-1051.

(24) Chen, L.; Yap, J. L.; Yoshioka, M.; Lanning, M. E.; Fountain, R. N.; Raje, M.; Scheenstra, J. A.; Strovel, J. W.; Fletcher, S. BRD4 Structure-Activity Relationships of Dual PLK1 Kinase/BRD4 Bromodomain Inhibitor BI-2536. ACS Med. Chem. Lett. 2015, 6, 764-769.

(25) Liu, S.; Yosief, H. O.; Dai, L.; Huang, H.; Dhawan, G.; Zhang, X.; Muthengi, A. M.; Roberts, J.; Buckley, D. L.; Perry, J. A.; Wu, L.; Bradner, J. E.; Qi, J.; Zhang, W. Structure-Guided Design and Development of Potent and Selective Dual Bromodomain 4 (BRD4)/ Polo-like Kinase 1 (PLK1) Inhibitors. J. Med. Chem. 2018, 77857795.

(26) Marsilje, T. H.; Pei, W.; Chen, B.; Lu, W.; Uno, T.; Jin, Y.; Jiang, T.; Kim, S.; Li, N.; Warmuth, M.; Sarkisova, Y.; Sun, F.; Steffy, A.; Pferdekamper, A. C.; Li, A. G.; Joseph, S. B.; Kim, Y.; Liu, B.; Tuntland, T.; Cui, X.; Gray, N. S.; Steensma, R.; Wan, Y.; Jiang, J.; Chopiuk, G.; Li, J.; Gordon, W. P.; Richmond, W.; Johnson, K.; Chang, J.; Groessl, T.; He, Y.-Q.; Phimister, A.; Aycinena, A.; Lee, C. C.; Bursulaya, B.; Karanewsky, D. S.; Seidel, H. M.; Harris, J. L.; Michellys, P.-Y. Synthesis, Structure-Activity Relationships, and in Vivo Efficacy of the Novel Potent and Selective Anaplastic Lymphoma Kinase (ALK) Inhibitor 5-Chloro-N2-(2-isopropoxy-5methyl-4-(piperidin-4-yl)phenyl)-N4-(2-(isopropylsulfonyl)phenyl)pyrimidine-2,4-diamine (LDK378) Currently in Phase 1 and Phase 2 Clinical Trials. J. Med. Chem. 2013, 56, 5675-5690.

(27) Kinoshita, K.; Kobayashi, T.; Asoh, K.; Furuichi, N.; Ito, T.; Kawada, H.; Hara, S.; Ohwada, J.; Hattori, K.; Miyagi, T.; Hong, W.- 
S.; Park, M.-J.; Takanashi, K.; Tsukaguchi, T.; Sakamoto, H.; Tsukuda, T.; Oikawa, N. 9-Substituted 6,6-Dimethyl-11-oxo-6,11dihydro-5H-benzo[b]carbazoles as Highly Selective and Potent Anaplastic Lymphoma Kinase Inhibitors. J. Med. Chem. 2011, 54, 6286-6294.

(28) Huang, W.-S.; Liu, S.; Zou, D.; Thomas, M.; Wang, Y.; Zhou, T.; Romero, J.; Kohlmann, A.; Li, F.; Qi, J.; Cai, L.; Dwight, T. A.; Xu, Y.; Xu, R.; Dodd, R.; Toms, A.; Parillon, L.; Lu, X.; Anjum, R.; Zhang, S.; Wang, F.; Keats, J.; Wardwell, S. D.; Ning, Y.; Xu, Q.; Moran, L. E.; Mohemmad, Q. K.; Jang, H. G.; Clackson, T.; Narasimhan, N. I.; Rivera, V. M.; Zhu, X.; Dalgarno, D.; Shakespeare, W. C. Discovery of Brigatinib (AP26113), a Phosphine Oxide-Containing, Potent, Orally Active Inhibitor of Anaplastic Lymphoma Kinase. J. Med. Chem. 2016, 59, 4948-4964.

(29) Achary, R.; Mathi, G. R.; Lee, D. H.; Yun, C. S.; Lee, C. O.; Kim, H. R.; Park, C. H.; Kim, P.; Hwang, J. Y. Novel 2,4Diaminopyrimidines Bearing Fused Tricyclic Ring Moiety for Anaplastic Lymphoma Kinase (ALK) Inhibitor. Bioorg. Med. Chem. Lett. 2017, 27, 2185-2191.

(30) Mathi, G. R.; Kang, C. H.; Lee, H. K.; Achary, R.; Lee, H.-Y.; Lee, J.-Y.; Ha, J. D.; Ahn, S.; Park, C. H.; Lee, C. O.; Hwang, J. Y.; Yun, C.-S.; Jung, H. J.; Cho, S. Y.; Kim, H. R.; Kim, P. Replacing the Terminal Piperidine in Ceritinib with Aliphatic Amines Confers Activities Against Crizotinib-resistant Mutants including G1202R. Eur. J. Med. Chem. 2017, 126, 536-549.

(31) Budin, G.; Yang, K. S.; Reiner, T.; Weissleder, R. Bioorthogonal Probes for Polo-like Kinase 1 Imaging and Quantification. Angew. Chem., Int. Ed. 2011, 50, 9378-9381.

(32) Baumeister, P.; Blaser, H.-U.; Studer, M. Strong Reduction of Hydroxylamine Accumulation in the Catalytic Hydrogenation of Nitroarenes by Vanadium Promoters. Catal. Lett. 1997, 49, 219-222.

(33) Filippakopoulos, P.; Qi, J.; Picaud, S.; Shen, Y.; Smith, W. B.; Fedorov, O.; Morse, E. M.; Keates, T.; Hickman, T. T.; Felletar, I.; Philpott, M.; Munro, S.; McKeown, M. R.; Wang, Y.; Christie, A. L.; West, N.; Cameron, M. J.; Schwartz, B.; Heightman, T. D.; La Thangue, N.; French, C. A.; Wiest, O.; Kung, A. L.; Knapp, S.; Bradner, J. E. Selective Inhibition of BET Bromodomains. Nature 2010, 468, 1067-1073.

(34) Mirguet, O.; Gosmini, R.; Toum, J.; Clément, C. A.; Barnathan, M.; Brusq, J.-M.; Mordaunt, J. E.; Grimes, R. M.; Crowe, M.; Pineau, O.; Ajakane, M.; Daugan, A.; Jeffrey, P.; Cutler, L.; Haynes, A. C.; Smithers, N. N.; Chung, C.-w.; Bamborough, P.; Uings, I. J.; Lewis, A.; Witherington, J.; Parr, N.; Prinjha, R. K.; Nicodème, E. Discovery of Epigenetic Regulator I-BET762: Lead Optimization to Afford a Clinical Candidate Inhibitor of the BET Bromodomains. J. Med. Chem. 2013, 56, 7501-7515.

(35) Fabian, M. A.; Biggs, W. H., III; Treiber, D. K.; Atteridge, C. E.; Azimioara, M. D.; Benedetti, M. G.; Carter, T. A.; Ciceri, P.; Edeen, P. T.; Floyd, M.; Ford, J. M.; Galvin, M.; Gerlach, J. L.; Grotzfeld, R. M.; Herrgard, S.; Insko, D. E.; Insko, M. A.; Lai, A. G.; Lélias, J.-M.; Mehta, S. A.; Milanov, Z. V.; Velasco, A. M.; Wodicka, L. M.; Patel, H. K.; Zarrinkar, P. P.; Lockhart, D. J. A Small Molecule-Kinase Interaction Map for Clinical Kinase Inhibitors. Nat. Biotechnol. 2005, 23, 329.

(36) Raab, M.; Krämer, A.; Hehlgans, S.; Sanhaji, M.; KurunciCsacsko, E.; Dötsch, C.; Bug, G.; Ottmann, O.; Becker, S.; Pachl, F.; Kuster, B.; Strebhardt, K. Mitotic Arrest and Slippage Induced by Pharmacological Inhibition of Polo-like Kinase 1. Mol. Oncol. 2015, 9, $140-154$.

(37) Tucker, E. R.; Tall, J. R.; Danielson, L. S.; Gowan, S.; Jamin, Y.; Robinson, S. P.; Banerji, U.; Chesler, L. Immunoassays for the Quantification of ALK and Phosphorylated ALK Support the Evaluation of On-target ALK Inhibitors in Neuroblastoma. Mol. Oncol. 2017, 11, 996-1006.

(38) Vasta, J. D.; Corona, C. R.; Wilkinson, J.; Zimprich, C. A.; Hartnett, J. R.; Ingold, M. R.; Zimmerman, K.; Machleidt, T.; Kirkland, T. A.; Huwiler, K. G.; Ohana, R. F.; Slater, M.; Otto, P.; Cong, M.; Wells, C. I.; Berger, B.-T.; Hanke, T.; Glas, C.; Ding, K.; Drewry, D. H.; Huber, K. V. M.; Willson, T. M.; Knapp, S.; Müller, S.;
Meisenheimer, P. L.; Fan, F.; Wood, K. V.; Robers, M. B. Quantitative, Wide-Spectrum Kinase Profiling in Live Cells for Assessing the Effect of Cellular ATP on Target Engagement. Cell Chem. Biol. 2018, 25, 206.e11-214.e11.

(39) Machleidt, T.; Woodroofe, C. C.; Schwinn, M. K.; Méndez, J.; Robers, M. B.; Zimmerman, K.; Otto, P.; Daniels, D. L.; Kirkland, T. A.; Wood, K. V. NanoBRET-A Novel BRET Platform for the Analysis of Protein-Protein Interactions. ACS Chem. Biol. 2015, 10, 1797-1804. 